$$
\begin{aligned}
& \text { UNIVERSIDADE DE SÃO PAULO } \\
& \text { FACULDADE DE FILOSOFIA, LETRAS E CIÊNCIAS HUMANAS } \\
& \text { DEPARTAMENTO DE LETRAS CLÁSSICAS E VERNÁCULAS }
\end{aligned}
$$

PROGRAMA DE PÓS-GRADUAÇÃO EM FILOLOGIA E LÍNGUA PORTUGUESA

\title{
A FRASE E SUA TEORIA \\ NO HORIZONTE DE RETROSPECÇÃO DE MATTOSO CÂMARA (VERSÃO CORRIGIDA)
}

FRANCIVALDO LOURENÇO DA SILVA

\author{
SÃO PAULO \\ 2019
}


UNIVERSIDADE DE SÃO PAULO

FACULDADE DE FILOSOFIA, LETRAS E CIÊNCIAS HUMANAS

DEPARTAMENTO DE LETRAS CLÁSSICAS E VERNÁCULAS

PROGRAMA DE PÓS-GRADUAÇÃO EM FILOLOGIA E LÍNGUA PORTUGUESA

\section{A FRASE E SUA TEORIA \\ NO HORIZONTE DE RETROSPECÇÃO DE MATTOSO CÂMARA (VERSÃO CORRIGIDA)}

FRANCIVALDO LOURENÇO DA SILVA

Dissertação apresentada ao

Programa de Pós-Graduação em

Filologia e Língua Portuguesa, do

Departamento de Letras Clássicas e

Vernáculas da Faculdade de

Filosofia, Letras e Ciências

Humanas da Universidade de São

Paulo, para obtenção do título de Mestre em Letras.

Orientadora: Prof ${ }^{\mathrm{a}}$. Dr ${ }^{\mathrm{a}}$. Marli Quadros Leite

SÃO PAULO 
Autorizo a reprodução e divulgação total ou parcial deste trabalho, por qualquer meio convencional ou eletrônico, para fins de estudo e pesquisa, desde que citada a fonte.

Catalogação na Publicação

Serviço de Biblioteca e Documentação

Faculdade de Filosofia, Letras e Ciências Humanas da Universidade de São Paulo

S581f Silva, Francivaldo A frase e sua teoria no

horizonte de retrospecção de Mattoso Câmara /

Francivaldo Silva ; orientadora Marli Leite. - São

Paulo, 2019.

$140 \mathrm{f}$.

Dissertação (Mestrado) - Faculdade de Filosofia, Letras e Ciências Humanas da Universidade de São Paulo. Departamento de Letras Clássicas e

Vernáculas. Área de concentração: Filologia e Língua Portuguesa.

1. Frase. 2. Linguística. 3. Gramática. 4. Filologia. I. Leite, Marli, orient. II. Título. 


\section{ENTREGA DO EXEMPLAR CORRIGIDO DA DISSERTAÇÃO/TESE}

Termo de Ciência e Concordância do (a) orientador (a)

Nome do (a) aluno (a): Francivaldo Lourenço

da Silva Data da defesa: 18/06/2019

Nome do Prof. (a) orientador (a): Marli

Quadros Leite

Nos termos da legislação vigente, declaro ESTAR CIENTE do conteúdo deste EXEMPLAR CORRIGIDO elaborado em atenção às sugestões dos membros da comissão Julgadora na sessão de defesa do trabalho, manifestando-me plenamente favorável ao seu encaminhamento e publicação no Portal Digital de Teses da USP.

São Paulo, 30/07/2019.

Mare: Quadros heite 


\section{FOLHA DE APROVAÇÃO}

Francivaldo Lourenço da Silva

A FRASE E SUA TEORIA NO HORIZONTE DE RETROSPECÇÃO DE MATTOSO CÂMARA

Dissertação apresentada ao

Programa de Pós-Graduação em

Filologia e Língua Portuguesa, do

Departamento de Letras Clássicas e

Vernáculas da Faculdade de Filosofia, Letras e Ciências Humanas da Universidade de São Paulo, para obtenção do título de Mestre em Letras.

Área de concentração: Filologia e Língua Portuguesa

Aprovado em: 18/ 06/ 2019

\section{Banca Examinadora}

Prof $^{\mathrm{a}}$. Dr ${ }^{\mathrm{a}}$. Marli Quadros Leite

Instituição: FFLCH - USP

Prof ${ }^{\mathrm{a}}$. Dr ${ }^{\mathrm{a}}$. Maria Mercedes Saraiva Hackerott

Instituição: UNIP

Prof. Dr. Marcelo Módolo

Instituição: FFLCH - USP

Prof. Dr. Jorge Viana de Moraes

Instituição: IFSP 


\section{DEDICATÓRIA}

Dedico este trabalho à Izabel do Nascimento Almeida, por ter estado lá quando pela primeira vez pretendi realizá-lo.

Também à Leila Cristiane Dias, que esteve lá quando pela primeira vez dei-me conta de que daria certo, eu o poderia realizar.

E, em memória, à Amara Lourenço da Silva, que esteve e estará sempre lá todas as vezes. 


\section{AGRADECIMENTOS}

Agradeço e dou graças a Nosso Senhor Jesus Cristo e à sua Mãe Imaculada; sem eles não teria nunca percebido que poderia ir além.

Agradeço à professora doutora Marli Quadros Leite, pelo acolhimento afetuoso e pelas preciosas orientações; as fichas continuam a cair.

Agradeço aos alunos da Sala de Recursos de Língua Portuguesa para Alunos Surdos e com Deficiência Auditiva, projeto da Secretaria de Educação de Praia Grande (SP), pela oportunidade que me dão diariamente de aprender com eles como melhor compreender a Língua Portuguesa; também à Rosinês Aparecida Nunes da Silva, por ter segurado as pontas muitas vezes e pela longa e produtiva parceria no trabalho.

Agradeço à Izabel do Nascimento Almeida e à Cleonice Rocha Sousa, pela amizade e pela ajuda na coleta de dados no Acervo Mattoso Câmara da Universidade Católica de Petrópolis, ainda que isto tenha significado abdicar de alguns passeios na bela Petrópolis.

Agradeço aos amigos Leila Cristiane Dias, Medson Miguel da Luz, Rosângela Eliane Pereira Rocha, Fábio de Paula Pires, Patrícia de Almeida Batista e Paulo Saul Duek, por não me deixarem esquecer que é preciso largar os livros, vez ou outra, para compartilhar uma garrafa de vinho e uma boa conversa com amigos queridos.

Agradeço a Benedito José da Silva, por ser um pai que ainda que não alcance as escolhas de um filho o deixa ir em frente.

Agradeço, por fim, à família Lourenço e seus numerosos amigos agregados, por me lembrarem sempre que não se está só quando se tem uma família como a nossa. 
Os horizontes, enfim, são a resultante estruturada das conquistas anteriores, tal como a condição e limitação dos desenvolvimentos futuros. Eles são estruturados. Todo aprendizado não é um simples acréscimo ao aprendizado anterior, mas um crescimento orgânico que nasce dele. [...] Os horizontes, portanto, representam a extensão de nossos interesses e nosso conhecimento; eles são a fonte fértil de novos conhecimentos e preocupações; ao mesmo tempo, também são as fronteiras que limitam nossa capacidade de assimilar mais do que já conseguimos.

Bernard LONERGAN (2012, p. 265) 


\section{RESUMO}

Este trabalho apresenta o percurso histórico da ideia de frase a partir de sua presença na obra do linguista brasileiro Joaquim Mattoso Câmara Jr. (1904-1970). Entende-se por ideia de frase as representações que pretendem dar conta dos segmentos da cadeia dialógico-discursiva no âmbito das ciências ou disciplinas dedicadas ao estudo qualificado e especulativo da linguagem. Partiu-se do problema geral da definição da frase e de seu papel no estudo da linguagem. Mattoso Câmara, como linguista brasileiro, ilustra, por meio de suas reflexões sobre a questão da frase e de seu horizonte de retrospecção, os movimentos e transformações do percurso histórico do problema considerado; contribuiu, também, com os capítulos XI e XII de seu Princípios de linguística geral $\left(1^{\text {a }}\right.$ ed., 1941) para o esforço de precisão conceitualterminológica da ideia de frase; o fez a partir da compreensão do caráter heteróclito da frase e de seu enquadramento teórico a partir da dicotomia saussuriana langue / parole. Este trabalho resulta do levantamento, a partir das pistas encontradas na obra de Mattoso Câmara, das emergências da ideia de frase e dos contextos epistemológicos em que surgem. O percurso de sua presença e de sua problematização no longo tempo do pensamento linguístico ocidental nos eixos espaço-temporais da Antiguidade Grega, da França racionalista e do Brasil que se moderniza permite compreender e localizar na história das ideias linguísticas brasileiras a contribuição de Mattoso Câmara à conceituação do termo frase. O viés teórico-metodológico deste trabalho é o da História das Ideias Linguísticas, na proposta do filósofo e historiador Sylvain Auroux. O cerne desta proposta teórico-metodológica é o saber metalinguístico constituído e/ou em vias de se constituir que pode ser de quatro tipos: especulativo, prático, técnico e competente (AUROUX, 1988). O conceito de ideia de frase subjacente a este trabalho resulta do saber metalinguístico de natureza especulativa, visto que é no âmbito do estudo qualificado que as representações que pretendem lidar com as entidades manifestadas no mundo sensível e identificadas pelos termos frase, sentença, oração, proposição, período e enunciado foram buscadas.

Palavras-chave: Frase. Linguística. Joaquim Mattoso Câmara Jr. Horizonte de Retrospecção. História das Ideias Linguísticas. 


\begin{abstract}
This work presents the historical course of sentence idea. The presence of discussions about sentence in the work of the Brazilian linguist Joaquim Mattoso Câmara Jr. (1904-1970) is the motive for elaboration of this historical course. Sentence idea is understood, in this work, by representations of dialogical-discursive chain segments in scope of sciences or disciplines dedicated to speculative study of language. It started from the general problem of defining the sentence and its role in the study of language. Mattoso Câmara's reflections about the sentence illustrate the movements of historical path of sentence idea. The same occurs with his retrospection horizon. The Chapters XI and XII of his Princípios de linguística geral (1st ed., 1941) are his contributions to the conceptual-terminological precision effort of sentence idea. He does so understanding the sentence's heteroclite character and its theoretical framework from the Saussurian dichotomy langue / parole. This work results from the survey of clues of sentence idea and the epistemological contexts in which they arise. Most of those clues was found in the work of Mattoso Câmara. The course of presence and problematization of sentence question in the long term of Western linguistic thought in the space-time axes of Greek Antiquity, Rationalist France, and Brazil that is modernized enables us to understand and locate in the history of Brazilian linguistic ideas the contribution of Mattoso Câmara to conceptualization of the term FRASE. The theoretical-methodological bias of this work is the History of Linguistic Ideas; it was proposal by the philosopher and historian Sylvain Auroux. The core of this theoretical-methodological proposal is the metalinguistic knowledge constituted and / or about to be constituted. They can be of four types: speculative, practical, technical and competent (AUROUX, 1988). The concept of sentence idea underlying this work results from the metalinguistic knowledge of a speculative nature, since it is from there that came the terms, in Portuguese, frase, sentença, oração, proposição, período e enunciado.
\end{abstract}

Keywords: Sentence. Linguistic. Joaquim Mattoso Câmara Jr. Retrospection Horizon. History of Linguistic Ideas. 


\section{RÉSUMÉ}

Ce travail présente le parcours historique de l'idée de phrase depuis sa présence dans l'œuvre du linguiste brésilien Joaquim Mattoso Câmara Jr. (1904-1970). On entend par l'idée de phrase les expressions des segments de la chaîne dialogico-discursive dans le champ des sciences ou disciplines consacrées à l'étude qualifiée et spéculative de la langue. Il est parti du problème général de la définition de la phrase et de son rôle dans l'étude du langage. Mattoso Câmara, en tant que linguiste brésilien, illustre, à travers ses réflexions sur la question de la phrase et son horizon de rétrospection, les mouvements et les transformations de la trajectoire historique du problème considéré; il a également contribué aux chapitres XI et XII de son livre Princípios de linguística geral (1er ed., 1941) pour l'effort de précision conceptuel-terminologique de l'idée de phrase; il l'a fait par la compréhension du caractère hétéroclite de la phrase et de son cadre théorique issu de la dichotomie saussurienne langue / parole. Ce travail résulte de l'enquête, des indices retrouvés dans les travaux de Mattoso Câmara, de l'émergence de l'idée de phrase et des contextes épistémologiques dans lesquels ils se développent. Le parcours de sa présence et sa problématisation à long terme de la pensée linguistique occidentale dans les axes espace-temps de l'Antiquité grecque, de la France rationaliste et du Brésil modernisés nous permettent de comprendre et de situer dans l'histoire des idées linguistiques brésiliennes la contribution de Mattoso Câmara à conceptualisation du terme FRASE. Le parti pris théorique de ce travail est l'Histoire des idées linguistiques, dans la proposition du philosophe et historien Sylvain Auroux. Le noyau de cette proposition théorique est constitué par les connaissances métalinguistiques constituées et / ou sur le point de l'être, qui peuvent être de quatre types: spéculatif, pratique, technique et compétent (AUROUX, 1988). La notion d'idée de phrase sous-jacente à ce travail résulte de la connaissance métalinguistique de nature spéculative, car c'est dans le cadre de l'étude qualifiée que les représentations destinées à traiter les entités manifestées dans le monde sensible et identifiées, en portugais, par les termes frase, sentença, oração, proposição, período e enunciado ont été recherchées.

Mots-clés: Phrase. Linguistique. Joaquim Mattoso Câmara Jr. Horizon de Rétrospection. Histoire des Idées Liguistiques. 


\section{SUMÁRIO}

INTRODUÇÃO 15

CAPÍTULO 1 - A ideia de FraSE: sua emergência na Antiguidade Clássica ................ 25

1.1 Pensamento e lógos: as questões da linguagem em Heráclito e Parmênides .................. 27

1.2 O marco inicial: Platão e sua Teoria do Lógos ................................................................. 29

1.3 Ampliando o marco inicial: Aristóteles e a Teoria dos Quatro Discursos ...................... 32

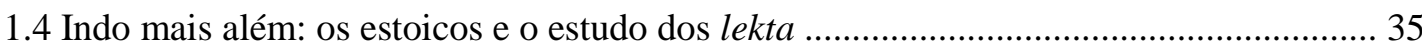

1.5 Nasce a gramaticologia ocidental: a Escola de Alexandria .............................................. 39

1.6 A FRASE na Antiguidade: Resultados “arqueológicos” .................................................. 41

1.7 A Antiguidade Clássica no Horizonte de Retrospecção de Mattoso Câmara .................. 42

1.7.1 O conceito de Horizonte de Retrospecção ..................................................... 42

1.7.2 O HR estruturado como saber histórico ........................................................ 44

CAPÍTULO 2 - O termo FRASE: de sua entrada em França a sua ida ao Brasil .......... 53

2.1 Panorama histórico das concepções de Gramática ............................................................ 54

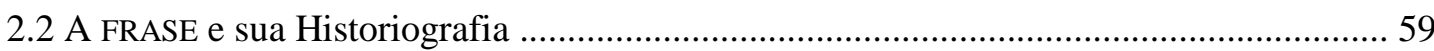

2.3 O termo FRASE e sua definição em França ....................................................................... 62

2.4 A FRASE em gramáticas brasileiras do Século XIX ………………………....................... 67

2.5 A FRASE na gramaticografia brasileira: Século XX ........................................................... 77

CAPÍTULO 3 - A FRASE: seu lugar no horizonte de retrospecção de Mattoso Câmara 85

3.1 Breve panorama da emergência das teorias enunciativas ................................................ 87

3.2 Mattoso Câmara: percurso acadêmico e profissional ....................................................... 89

3.3 Mattoso e o sistema científico (SC) de sua época ............................................................... 95

3.4 O programa linguístico de Mattoso Câmara: língua e estilo .............................................. 101

3.5 Configuração do horizonte de retrospecção (HR), quanto à frase, de Mattoso Câmara ...104

3.5.1 Mattoso Câmara e a linguística nova (sincrônica, descritiva ou estática) ..........105

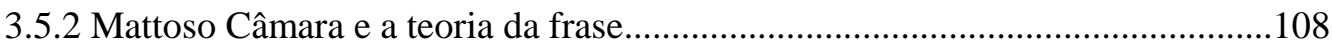

3.5.3 A questão da análise e dos padrões da frase portuguesa.....................................116 
ANEXO I Documento Notas para uma tese sobre sintaxe portuguesa presente no Acervo Mattoso Câmara da Universidade Católica de Petrópolis.

ANEXO II Páginas datilografadas de uma versão em português da História da linguística presente no Acervo Mattoso Câmara da Universidade Católica de Petrópolis.

ANEXO III Padrões frasais da língua portuguesa analisados em História e estrutura da língua portuguesa 


\section{ÍNDICE DE FIGURAS, QUADROS E LINHAS DO TEMPO}

FIGURA 1 Economia da semântica estoica segundo REY (1973)................................36

FIGURA 2 Divisão estoica dos lektá a partir de Bochenski (1966)...............................37

FIGURA 3 Verbete phrasis no Dicionário Grego-Francês de A. Bailly.........................66

FIGURA 4 Esquema da linguística lato sensu em Mattoso (1975, p. 29).....................102

QUADRO 1 Esquema parcial da classificação estoica dos enunciados significantes....38

QUADRO 2 Categorias de análise dos modos de apresentação de C em HR................44

QUADRO 3 Estrutura da sentença em Morais Silva (1806).........................................70

QUADRO 4 Equivalência dos termos referentes ao conjunto frásico...........................78

QUADRO 5 Mostra da presença da frase em gramáticas brasileiras............................83

QUADRO 6 Emergência das Teorias Enunciativas.......................................................88

QUADRO 4 O Círculo Linguístico de Praga no capítulo XI dos Princípios...............112

LINHA DO TEMPO 1: Percurso histórico do termo frase adaptado de Léon (2003)....64

LINHA DO TEMPO 2: Atuação profissional de Mattoso Câmara em confronto com o desenvolvimento institucional da Linguística no Brasil..................................................94 
SC - Sistema Científico

HR - Horizonte de Retrospecção

AS - Ato de Saber

$\mathrm{C}-$ Conhecimento

HC - História da Ciência

EC - Enunciados Científicos

PL - Pensamento Linguístico

CE - Contexto Epistêmico

EI - Emergência da ideia

LLG - Lições de Linguística Geral

CLP-G - Curso de Língua Pátria-Gramática

TAL - Teoria da Análise Léxica 


\section{INTRODUÇÃO}

A expressão 'ideia de frase', utilizada ao longo deste relato, aponta, a nosso ver, para a importante questão da conceituação deste fenômeno linguístico. Considerá-lo um fenômeno implica já uma série de necessárias ponderações: a LINGUAGEM como "faculdade que tem o homem de manifestar seus estados mentais (CÂMARA JR, 1970, p. 249)" realiza-se por meio da LÍNGUA, entendida esta no sentido corrente como "um sistema de signos vocais ${ }^{1}$ específicos aos membros de uma mesma comunidade (DUBOIS,1978, p. 378)"; a língua, por sua vez, é também realidade - no sentido que este termo adquire na filosofia de Flusser (2007, p. 41):

Se definimos realidade como "conjunto de dados", podemos dizer que vivemos em realidade dupla: na realidade das palavras e na realidade dos dados "brutos" ou "imediatos". Como os dados "brutos" alcançam o intelecto propriamente dito em forma de palavras, podemos ainda dizer que a realidade consiste de palavras e de palavras in statu nascendi. Com esta afirmativa teremos assumido uma posição ontológica.

Então, a língua é realidade, assegura-nos Flusser (ibid.), na medida em que as palavras que chegam até nós através dos sentidos vêm organizadas. São agrupadas em obediência a regras preestabelecidas, formando frases. Quando percebemos palavras, diz ainda Flusser, percebemos uma realidade ordenada, um cosmos. O conjunto de frases percebidas e perceptíveis chamamos de língua. Concluí o filósofo, portanto, que a língua é o conjunto de todas as palavras percebidas e perceptíveis, quando ligadas entre si de acordo com regras preestabelecidas.

Tenhamos presente também, nessa ordem de ponderações, as palavras de Eugenio Coseriu, que quanto à essência da linguagem, ao considerá-la uma das duas dimensões essenciais do ser do homem - sendo a outra o trabalho - afirma:

Mediante el trabajo, el hombre se contruye sin cesar un mundo apropriado a su ser físico, mientras que mediante el lenguaje se construye un mundo apropriado a su ser espiritual: un mundo pensable (el mundo de la experiencia sensible, aunque es representable, no es pensable). De ahí que el linguaje sea "el aceso" a todas las

\footnotetext{
${ }^{1}$ Também signos visuais no caso das línguas de sinais.
} 
possibilidades culturales del hombre (incluídos el pensamiento discursivo, la ciência, la filosofía, la poesia) ${ }^{2}$ (COSERIU, 2012, p. 49).

Ambos os dois estudiosos concordam que a linguagem instaura uma realidade, um mundo próprio. Flusser (2007, p. 42) toma, no entanto, a palavra como elemento fundamental do cosmos da língua; Coseriu (2012, p. 51), por outro lado, toma o significado como elemento fundamental da linguagem. Adotamos neste trabalho uma perspectiva que talvez possamos chamar de holística, pois entendemos que é a frase, com todo o seu caráter heteróclito e fronteiriço ${ }^{3}$, o elemento de base: nela manifesta-se plenamente, a nosso ver, o caráter simbólico da palavra; e, também, é em sua articulação que se instaura o significado. É este o fundamento filosófico de que partimos para justificar nosso interesse pela ideia de frase.

Este trabalho justifica-se por ser a ideia de frase um conceito fundamental para se pensar a natureza da linguagem, de modo que a própria história do pensamento linguístico ocidental está marcada por suas emergências em pontos importantes de inflexão: na própria origem desta tradição, com a Teoria do Lógos platônica, ou mesmo antes, com as reflexões aceca do lógos em Heráclito e Parmênides; na formação da gramaticografia ocidental com Dionísio da Trácia, que nos legou, em sua conceituação da frase, o traço conceitual "manifesta um pensamento completo" que ainda hoje gera debates; no repensar da sintaxe ocorrida com o racionalismo francês fundamentado na noção de proposição que predominou nas gramáticas que se alinharam a esta corrente de pensamento; e contemporaneamente, em importantes correntes da linguística teórica, tais como o estruturalismo e o gerativismo.

A ideia de frase ora emergiu como fronteira para outros fatos linguísticos de maior interesse (estudos das articulações sintáticas e prosódicas, bem como das partes do discurso), ora como construto analisável em suas partes constituintes (análise lógica, análise léxica, construção), ora como unidade estereotipada (fraseologia, frase francesa, frase portuguesa etc.), ora como estrutura de base (teoria gerativa-transformacional); no

\footnotetext{
${ }^{2}$ Traduzimos: "Por meio do trabalho, o homem constrói para si, sem cessar, um mundo apropriado a seu ser físico, ao passo que por meio da linguagem constrói para si um mundo apropriado a seu ser espiritual: um mundo pensável (o mundo da experiência sensível, ainda que representável, não é pensável). Daí que a linguagem seja «o acesso » a todas as possibilidades culturais do homem (incluídos o pensamento discursivo, a ciência, a filosofia, a poesia)".

${ }^{3}$ No sentido que nos dá o Minidicionário de Caldas Aulete (2011, p. 426) daquilo que está na fronteira de, no limite.
} 
entanto, sua presença é constante e necessária na medida em que toda reflexão linguística é concorde quanto ao fato de que a linguagem é percebida na interação entre humanos e que para tanto unidades simples não são funcionais, sendo necessário que tais, paulatinamente, tornem-se mais e mais complexas, gerando unidades cada vez maiores até ao ponto da comunicabilidade plena.

Deste modo não acompanhamos o historiador da língua francesa, Jean-Pierre Seguin, que toma a frase como um mero signo em si mesmo, fazendo parte da metalinguagem de seu país e cuja história é "une enquete sur l'aventure discursive du mot ${ }^{4}$ " (SEGUIN, 1993, p. 13); nosso relato, portanto, não seguirá os pressupostos de qualquer análise do discurso.

Para além de termo especializado, FRASE, para nós, é também a representação de um fenômeno linguístico, portanto, constitui uma ideia linguística, no que seguimos Sylvain Auroux (1989, p.15), que por ideia entende saber ou representação geral; aliando esta palavra ao termo linguística em seu sentido comum de concernente à linguagem, Auroux funda a disciplina História das Ideias Linguísticas. A frase, como ideia linguística, gerou no longo tempo do pensamento linguístico ocidental um significativo complexo conceitual-terminológico, importante nas reflexões especializadas acerca da linguagem. Concebemos a história desta ideia linguística, então, como sendo o levantamento das suas emergências no longo tempo, considerando a articulação entre a representação da ideia, a terminologia empregada para lidar com ela e o seu desempenho na produção de saberes linguísticos.

Auroux (1988), classifica estes saberes, em quatro tipos possíveis: 1) o saber de natureza especulativa; 2) o saber de natureza prática, determinado por três tipos de mestria, a saber, a) de enunciação, b) de língua e c) de escrita; 3) o saber técnico constituído a partir das mestrias; 4) o saber especializado, formado por competências específicas, passíveis de receberem um status profissional numa dada sociedade. $\mathrm{O}$ conceito de ideia de frase subjacente ao nosso relato resulta do saber metalinguístico de natureza especulativa, na medida em que é no âmbito do estudo qualificado que as representações que pretendem lidar com as entidades manifestadas no mundo sensível e identificadas pelos termos frase, sentença, oração, proposição, período e enunciado, foram buscadas.

\footnotetext{
${ }^{4}$ Traduzimos: "um inquérito sobre a aventura discursiva da palavra".
} 
De modo sucinto, por ideia de frase entendemos as representações que pretendem dar conta dos segmentos da cadeia dialógico-discursiva no âmbito das ciências ou disciplinas dedicadas ao estudo qualificado e especulativo da linguagem.

A ideia de frase, como a entendemos, será observada em dois âmbitos de investigação: o primeiro deles será o das problemáticas que são inerentes ao processo de sua conceitualização; o segundo, o de um momento particular de sua emergência, a saber, sua presença na obra do linguista brasileiro Joaquim Mattoso Câmara Jr.

O viés teórico-metodológico deste trabalho é o da História das Ideias Linguísticas, na proposta do filósofo e pesquisador Sylvain Auroux. O cerne desta proposta teórico-metodológica é o saber metalinguístico constituído e/ou em vias de se constituir. Ele pode ser, como vimos, de quatro tipos: especulativo, prático, técnico e competente (AUROUX, 1988). Tal classificação tem por base a concepção de que:

Le savoir linguistique est multiple et il débute naturellement dans la conscience de l'homme parlant. Il est épilinguistique, non posé pour soi dans la représentation avant d'être métalinguistique, c'est-à-dire représenté, construit et manipulé en tant que tel ${ }^{5}$. (AUROUX, 1988, p. 429)

Esta duplicidade da manifestação do saber linguístico (na consciência do falante e na sua representação como tal) faz com que nos interroguemos acerca da constituição mesma das ideias por traz destes saberes. Entendemos, neste aspecto, que as ideias - no caso, as ideias linguísticas - têm maior autonomia que o saber - também linguístico -, posto que o saber implica um sujeito que saiba, enquanto que a ideia é um elemento mesmo da estrutura da realidade, no caso, da realidade da linguagem, entendida como a única forma absolutamente geral de que o homem dispõe para fixar e para tornar objetivo, para além das impressões e reações imediatas, o conhecimento do mundo e de si mesmo, ou seja, todo o conteúdo da consciência (COSERIU, 1969, p. 240).

A percepção de que precisamos lançar mão de um todo unificado para externar um sentido único a ser comunicado é uma constante na tradição ocidental dos estudos da linguagem. Swiggers (1997) afirma mesmo que a gramática ocidental tem sua

\footnotetext{
5 Traduzimos: "O saber linguístico é múltiplo e surge naturalmente na consciência do falante. É ele epilinguístico, ou seja, não se coloca por si mesmo na representação antes de tornar-se metalinguístico, quer dizer representado, construído e manipulado como tal”.
} 
origem no discurso e em sua análise filosófica e retórica. Ainda que ela tenha privilegiado as partes do discurso como elemento linguístico prioritário, podemos identificar aquela percepção na origem de suas primeiras especulações.

Assim, podemos reportar aos gregos as primeiras emergências do saber epilínguístico acerca da ideia de frase; bem como, as suas primeiras representações metalinguísticas, sobretudo, por meio do termo lógos e das especulações filosóficas e gramaticais que tal conceito e termo suscitaram. A passagem do saber epilinguístico ao saber metalinguístico se dá por meio das representações que neste processo são elaborados. Constitui, precisamente, tarefa do historiador das ideias linguísticas precisar os momentos em que tais representações, materializadas em proposições, tornaram-se conhecidas (AUROUX, 1986), bem como o papel que desempenharam na configuração do estado das ciências da linguagem que, como contexto, as tenham acolhido.

Para Auroux (2008) representações são impressões que afetam os seres vivos de tipo "animal" e possuem a propriedade de serem automaticamente relacionadas/relacionáveis aos objetos e aos sujeitos do mundo exterior, não simplesmente como causas, mas como algo que pode eventualmente valer em seu lugar. A propriedade de a representação poder substituir os objetos e os sujeitos, a nosso ver, é o que inaugura o fluxo das ideias na História. Ainda para o autor, a verdade não tem história, mas o conhecimento a tem (AUROUX, 1986); no entanto, os conhecimentos não são eventos, portanto, não são datáveis; apenas suas eventuais aparições é que o são (AUROUX, 2006). E ainda, a representação humana é, com efeito:

caracterizada pela importância das externalidades cognitivas (os livros, as bibliotecas, as calculadoras etc.) que levam a ultrapassar as capacidades individuais por meio de instrumentos técnicos e significantes. Pode-se mesmo dizer que são estas externalidades que explicam a natureza e os desempenhos das representações mais características da humanidade, como são as que constituem a ciência. (AUROUX, 2008 (a), p. 125).

Para a compreensão de nosso objeto de investigação lato sensu (a Teoria da Frase) procuramos observar as articulações teórico-metodológicas surgidas a partir das formulações conceituais sobre a frase e seus correlatos; procuramos, assim, analisar o saber metalinguístico elaborado acerca da frase. Tomamos nosso objeto de investigação stricto sensu (a teoria da frase em Mattoso Câmara) como saber metalinguístico 
especulativo, na medida em que Mattoso pretende uma apresentação teoricamente abrangente da frase. No entanto, o historiador das ciências deve ser um pesquisador que se interesse por um domínio empírico, onde encontra os dados materiais (documentos, arquivos etc) e os fatos (a publicação de um livro, a falsificação de uma teoria etc). Por outro lado:

a história das ciências não poderia ser uma história empírica. Ela não poderia ser descrita na fragmentação dos fatos, visto que ela é essencialmente, em suas formas elevadas, a história do progresso das relações racionais do saber. $\mathrm{Na}$ história das ciências além do liame de causa e efeito, estabelece-se um vínculo de razão e consequência. (BACHELARD, 1977, p. 190).

A partir destes pressupostos, compreendemos, neste trabalho, as implicações metodológicas da escolha do campo de estudos da História das Ideias Linguísticas nos seguintes termos:

- o contexto situacional de referência é, necessariamente, amplo, na medida em que buscamos as origens e os desenvolvimentos das ideias linguísticas, independente dos campos onde tenham surgido;

- o componente epistemológico fundamental na composição da trama e na seleção de seus personagens significativos é marcado pelo traço descritivo, assim, o que se pretende, também, é localizar num quadro intelectual, cognitivo e epistêmico, a ideia investigada;

- o produto de tal trabalho concretiza-se no fornecimento de uma explanação fundamentada da causalidade (da ideia), das configurações de permanência (desta mesma ideia) e da capacidade compreensiva da linguagem (fornecida por esta ideia) como dimensão humana da realidade.

Tomamos como categorias de análise, neste trabalho, os aspectos analítico e holístico propostos por Graffi (2001); o primeiro deles dá conta da estrutura gramatical da sentence e o segundo do fato de ser ela a expressão de um "pensamento completo". Apoiamo-nos, igualmente, na concepção de epistemologia descritiva (AUROUX, 1980) que toma as ciências como fatos e se esforça por construir uma reflexão coerente sobre 
seus diferentes aspectos (teóricos, sociológicos e práticos). Desta forma, para Auroux (ibid.) a história da ciência pode ser considerada como uma parte da epistemologia descritiva, caracterizada por uma dimensão temporal. Importa, no entanto, continua ele, distinguir entre a pura descrição de uma teoria passada (temporalidade externa) e a tentativa de construir modelos de avaliação, de fato explicações das mudanças (temporalidade interna).

O principal instrumento de análise de que lançamos mão é o horizonte de retrospecção, HR, cujo conceito é apresentado e discutido, dentre outros, em AUROUX (1986, 1999, 2006). O conceito designava, inicialmente, apenas o conjunto de referências a trabalhos anteriores, presente como conteúdo no discurso científico. Em outro momento, foi utilizado para designar a percepção que dado autor tinha das obras que antecediam a sua. Por fim, passou a designar, também, o conjunto de conhecimentos anteriores de que o cientista dispõe no momento de sua atuação cognitiva frente a um problema. Auroux (2006) ressalta, também, que devemos ter em conta as modalidades intrínsecas de afecção temporal dos objetos (sua "historicização", ou seja, seu modo de ser na "história real").

Para o devido enquadramento linguístico da questão - não apenas no âmbito da Antiguidade Clássica, mas também no longo tempo de sua presença no pensamento ocidental - apoiamo-nos nos conceitos de "nível universal da linguagem" e o de "programa de correspondência".

O primeiro deles foi formulado por Eugenio Coseriu nos seguintes termos:

La definición general del lenguaje como actividad humana universal ejercida individualmente siguiendo normas históricamente dadas conlleva la distinción de tres niveles en el ámbito de lo lingüístico: a) el nivel universal, el hablar o el lenguaje en general, previo a toda distinción de las lenguas; b) el nivel histórico, es decir, el de las lenguas históricas [=idiomas] o el de las lenguas en plural, determinadas con adjetivos propios que las identifican (alemán, francés, ruso, etc.); y c) el nivel de los textos, de los actos lingüísticos conexos que realiza un determinado hablante en una situación concreta, que, naturalmente, pueden producirse en forma hablada o escrita ${ }^{6}$ (COSERIU, 2007, p. 86)

\footnotetext{
6 Traduzimos: "A definição geral da linguagem como atividade humana universal, exercida individualmente seguindo normas historicamente dadas, implica a distinção de três níveis no âmbito linguístico: a) o nível universal, o falar ou a linguagem em geral, prévia a toda distinção das línguas; b) o nível histórico, quer dizer, o das línguas históricas [=idiomas] ou das línguas no plural, determinadas por adjetivos próprios que as identificam (alemão, francês, russo, etc.); e c) o nível dos textos, dos atos
} 
O segundo foi muito bem exposto por Pierre Swiggers (2005, p. 130):

\begin{abstract}
le programme de correspondance [vise] à établir une corrélation entre la langue, la pensée et la réalité. Ce modèle a une conception plutôt « instrumentaliste » de la langue (...). Dans le programme de correspondance, la description de la langue n'est pas restreinte à l'ossature grammaticalle : elle englobe aussi les procédés stylistiques et rhétoriques. De façon négative, on pourrait caractériser le programme de correspondance par l'intérêt très réduit accordé à la diversité sociale et à la dimension historique des langues?
\end{abstract}

Partimos do problema geral encontrado ao compulsarmos a produção bibliográfica (manuais, gramáticas, dicionários monolíngues e especializados, ensaios, artigos, teses etc.) de vários ramos das ciências da linguagem; deparamo-nos, em muitos deles, com o problema da definição da frase e de seu papel no estudo da linguagem; ou ainda, com a total ausência de qualquer definição ou problematização desta questão. Em filosofia da linguagem, sobretudo, nos primórdios do pensamento filosófico na Antiguidade Clássica, grande parte daquilo que o conceito moderno de frase recobre estava ao abrigo do termo lógos. Em gramática o problema da definição torna-se mais evidente, pois neste campo o termo FRASE foi constantemente posto em equivalência com os termos ORAÇÃO, PERÍODO, PROPOSIÇÃO e SENTENÇA. Em linguística, sobretudo a partir da distinção saussuriana entre langue e parole, o termo frase passou a representar um conceito chave em muitas teorizações que a ele se filiam.

O contexto referido no parágrafo anterior levou-nos à formulação das seguintes perguntas:

- Como se configurou o problema da conceitualização do fenômeno frase no longo tempo?

\footnotetext{
linguísticos conexos realizados por um determinado falante em uma situação concreta, que, naturalmente, podem ser realizados de forma oral ou escrita".

7 Traduzimos: "o programa de correspondência [visa] estabelecer uma correlação entre a língua, o pensamento e a realidade. Este modelo possui uma concepção extremamente "instrumentalista" da língua (...). No programa de correspondência, a descrição da língua não se restringe a ossatura gramatical; engloba, igualmente, os procedimentos estilísticos e retóricos. De forma negativa, pode-se caracterizar o programa de correspondência pelo pouco interesse apresentado com relação à diversidade social e à dimensão histórica das línguas".
} 
- Como Mattoso Câmara, no contexto linguístico brasileiro, caracterizou tal problema e de que modo o resolveu?

A hipótese que então formulamos é a de que Mattoso Câmara, como linguista brasileiro, ilustra por meio de suas reflexões sobre a questão da frase e de seu horizonte de retrospecção os movimentos e transformações do percurso histórico de nosso problema, bem como contribuiu com os capítulos XI e XII de seu Princípios de linguística geral (1 $1^{\mathrm{a}}$ ed., 1941) para o esforço de precisão conceitual-terminológica da ideia de frase, e o fez a partir da compreensão do caráter heteróclito da frase e de seu enquadramento teórico a partir da dicotomia saussuriana langue / parole.

Nosso objetivo foi, assim, empreender o levantamento, a partir das pistas encontradas na obra de Mattoso Câmara, das emergências da ideia de frase e dos contextos epistemológicos em que surgem; desta forma pretendemos traçar o percurso de sua presença e de sua problematização no longo tempo do pensamento linguístico ocidental; para tanto nos ativemos aos eixos espaço-temporais da Antiguidade Grega, da França racionalista e do Brasil que se moderniza; e, por meio deste percurso, compreender e localizar historicamente a contribuição de Mattoso Câmara à conceituação do termo frase.

De acordo com Lonergan (2012, p. 163) "a história só nasce a partir de uma série de pesquisas específicas e gerais, de monografias e comentários”, desta forma os três capítulos que compõem esta dissertação refletem os três objetos de pesquisa específicos sobre os quais se fundamenta nossa interpretação da história da conceitualização do termo frase, tema geral de nosso trabalho: o lógos na filosofia da Antiguidade grega (Capítulo 1); a frase e seus termos correlatos na gramaticografia francesa e brasileira (Capítulo 2); e a frase na linguística geral de Mattoso Câmara (Capítulo 3).

No Capítulo 1 ocupamo-nos com a emergência da frase no contexto da Antiguidade grega; começamos por refletir sobre a proposta de Pagliaro de que os présocráticos interessaram-se mais pela validade da frase que pela validade do nome; seguimos com a teoria do lógos elaborada por Platão e desenvolvida por Aristóteles e pelos estoicos; passamos para a definição de frase de Dionísio da Trácia cuja Téchne Grammatikè funda a gramaticografia ocidental; encerramos o capítulo analisando a 
presença destes conhecimentos no Horizonte de Retrospecção de Mattoso Câmara. O problema da conceituação da frase aparece neste momento ligado ao contexto epistêmico filosófico, portanto fundamentando soluções a problemas lógico-filosóficos e, não, a problemas eminentemente linguísticos.

No Capítulo 2, estes problemas linguísticos surgirão no contexto epistêmico gramatical vigente na França dos séculos XVII e XVIII e no Brasil do século XIX, trazendo ainda marcas do contexto epistêmico filosófico, mas transitando já para o contexto epistêmico linguístico. As causas e efeitos da atenção dada à frase nestas tradições ensejam o desenho dos rumos tomados pela problematização da conceituação da frase, que a partir daí passa a ser colocado em termos estritamente - ainda que não puramente - linguísticos. Vemos, por exemplo, a consolidação da chamada análise lógica da frase, fortemente criticada por Mattoso, bem como a predominância da equivalência (ou confusão) terminológica que, a nosso ver, embotou por longo tempo a teoria geral da frase. Ao final deste capítulo vislumbramos os contornos da caracterização deste problema e da proposta de solução; elaboradas ambas, caracterização e solução, por Mattoso Câmara.

No Capítulo 3 ocupamo-nos mais detidamente do pensamento linguístico de Mattoso Câmara, a partir do qual traçamos a faceta de seu horizonte de retrospecção ligada à questão da frase. Assim discutimos sua concepção de linguística geral, vinculada à filosofia linguística de Edward Sapir, sua filiação à vertente saussuriana que ensejou a emergência das teorias enunciativas, Albert Sechehaye, Charles Bally e Alan Gardiner, bem como o conceito de frase que elaborou em seus trabalhos sobre linguística geral, em suas críticas à análise lógica da frase e nos seus esforços de descrição da língua portuguesa. Esta conceituação aparece delineada cedo em suas Lições de linguística geral (1939-1941), no entanto, foi, posteriormente, reelaborada nas sucessivas edições de seu Princípios de linguística geral (4 edições ${ }^{8}$ ) sobretudo a partir dos conhecimentos auferidos junto ao Círculo Linguístico de Praga.

\footnotetext{
${ }^{8}$ De acordo com Cabral (2005, p. 223) as edições do Princípios são quatro: a $1^{\text {a }}$ de 1941 pela F. Briguet Editores, a $2^{\mathrm{a}}$ de 1954, a $3^{\mathrm{a}}$ de 1959 e $4^{\mathrm{a}}$ de 1964 pela Livraria Acadêmica. Ainda de acordo com a pesquisadora "há cinco publicações [a primeira sendo as Lições na Revista de Cultura e as outras em edições individuais] em vida do autor, todas por ele validadas, não havendo motivos para duvidar da autenticidade das inúmeras modificações introduzidas nos textos, de edição para edição, o que vale dizer que as variantes neles registradas podem ser atribuídas à inteira responsabilidade de seu autor."
} 


\section{Capítulo 1}

\section{A IDEIA DE FRASE: sua emergência na Antiguidade Clássica}

Neste capítulo apresentamos a emergência da FRASE no contexto da Antiguidade, sobretudo a Clássica, período seminal da história intelectual do Ocidente, dominado pelas civilizações grega e romana. O que encontramos de relevante neste período diz respeito à conceituação do termo lógos sob bases epistemológicas melhor elaboradas e numa perspectiva linguística ${ }^{9}$ clara. Platão e Aristóteles são os criadores de uma teoria do lógos que repercute ainda hoje nos estudos linguísticos.

Podemos tomar a concepção filosófica do lógos como a mais remota emergência da ideia de frase. Os pontos mais distanciados desta emergência encontram-se nas reflexões dos pré-socráticos, sobretudo, Heráclito e Parmênides, que refletiram sobre "a validade cognoscitiva da frase" (PAGLIARO, 1967). Antes da atenção dada por Platão às partes do lógos, o interesse ou se dirigia ao discurso em bloco, objeto da retórica (os modos de torná-lo eficiente e embelezá-lo), ou se dirigia aos elementos sonoros, ou aos nomes (a verificação do correto uso). Os sofistas eram os maiores interessados nas questões envolvendo a dialética e a retórica, disciplinas que lidavam, sobretudo, respectivamente, com a persuasão por meio do discurso e com a eficácia da arte do falar; não faziam eles, no entanto, nenhuma distinção do lógos em sua organização, e nenhuma atenção davam a uma análise da frase, à consideração dos seus membros ou da relação entre eles (NEVES, 2005, p. 10).

Com Platão, o aspecto analítico da reflexão sobre a frase passou a ocupar o centro das teorizações. Aristóteles examinou mais explicitamente a articulação dos termos no discurso, bem como, ao debruçar-se sobre o lógos, pôs em equação as relações entre a linguagem e a não-linguagem ${ }^{10}$ (id. ibid., p. 64); foi ele o mais brilhante discípulo de Platão; notórias são as divergências doutrinárias que contrapõem seu

\footnotetext{
${ }^{9}$ Trata-se de uma perspectiva que toma a linguagem como um fenômeno em si, ainda que a prioridade de seu estudo fosse estabelecer uma doutrina da verdade ou suas funcionalidades lógico-discursivas; ainda uma advertência: a palavra "linguística" está sendo usada neste contexto como adjetivo, referente à linguagem, e não como ciência, no conceito moderno desta palavra.

${ }^{10}$ NEVES (2005, p. 63): "É o marco da dissociação, de um lado, entre o real e a linguagem que o nomeia, de outro, entre a linguagem e o pensamento. Situado no plano da idéia, o significado se distingue do referente material. Também distinto do significante, preexiste a ele e o domina”.
} 
pensamento ao do grande mestre, sobretudo quanto à relação entre as coisas e as ideias $^{11}$, bem como sobre a dialética aos moldes platônicos, que considerava limitante na medida em que não levava a um conhecimento positivo (MORA, 2004, p. 181). Para suprir, de algum modo, esta lacuna deixada pela filosofia platônica, Aristóteles elaborou o Organon, que é precisamente a lógica; na esteira, no entanto, do próprio Platão e de sua teoria do lógos. Ao lado das investigações lógico-formais encontram-se em sua obra abundantes análises semióticas, em particular, semânticas (id. ibid.). O que demostra a importância que a reflexão sobre a linguagem teve em sua filosofia.

O aspecto holístico do estudo da frase, ou seja, aquele que a considera a partir de sua capacidade de ser a expressão de um "pensamento completo" (GRAFFI, 2001, p. 111) pode ser encontrado no pensamento estoico a partir do conceito de lektón (o que significa quando se fala com sentido; o significado, objetivamente). Em seus estudos dialéticos, os estoicos ainda distinguem a voz (phoné), a dicção (léxis) e o enunciado (lógos). A voz se diferencia da dicção porque esta é um som que pode ser grafado, enquanto qualquer som é voz. O enunciado, por sua vez, diferencia-se da dicção porque tem sempre um sentido, enquanto a dicção pode não ter sentido. O dizer (tó légein) e o proferir (tó prophéresthai) são duas coisas diferentes porque o que se pronuncia são os sons (phoné) e o que se diz são as coisas (prâgma), que podem ser ditas (lékton). O significado é sempre a base da preocupação linguística dos estoicos (NEVES, 2005, pp. 88-9).

Até aqui o que temos, de certo modo, é o mesmo ambiente epistemológico: a filosofia como meio de pensar as grandes questões, incluindo aí a linguagem. De acordo com Righi (1969, p. 48) durante o período ático, de Protágoras a Aristóteles, os estudos linguísticos, literários, retóricos e estéticos foram de natureza filosófica, pois eram feitos na base de distinções teóricas e com o objetivo de afirmar uma verdade e não de obter classificações cômodas, empiricamente comprováveis e úteis na prática.

Com os estoicos, a preocupação com as "classificações cômodas" aumentou consideravelmente; elaboraram eles sofisticada terminologia, apropriada a análises linguísticas apuradas; no entanto, é com os alexandrinos - filólógos da escola de Alexandria, centro cultural do helenismo -, no contexto de intensos e apurados estudos

\footnotetext{
${ }^{11}$ MORA (2004, p. 183): “O que Aristóteles justamente censurará em Platão será sempre a desnecessária duplicação das coisas, assim como a tendência a manter as coisas afastadas das ideias”.
} 
de crítica textual, que a disciplina gramatical surge e adquire seus contornos mais duradouros; é também no manual em que se agrupou o corpo coerente de sua doutrina (LEROY, 1971, p. 18) que encontramos a definição paradigmática da frase. Na Téchne Grammatiké de Dionísio da Trácia encontra-se:

Palavra é a menor parte de uma frase bem constituída. Frase é um grupamento ordenado/composição de palavras em prosa que manifesta um pensamento completo. A frase tem oito partes: nome, verbo, participio, artigo, pronome, preposição, advérbio, conjunção. O apelativo surge como uma das espécies de nomes. (tradução de CHAPANSKI, 2003, p. 26)

A partir daí a linguagem despida da roupagem dialético-filosófica passa a ser vista como uma forma linguística (grupamento ordenado de palavras), com um conteúdo próprio (pensamento completo) a ser, por meio dela, expresso (manifestação); também como um composto de elementos, igualmente, linguísticos (tem oito partes); ou seja, passa a exibir sua couraça gramatical.

Veremos nos tópicos que seguem alguns aspectos relevantes da presença do lógos nas reflexões de Heráclito e de Parmênides (1.1), da teoria do lógos elaborada por Platão (1.2), da análise aristotélica (1.3), da classificação estoica dos enunciados (1.4) e das repercussões da definição de frase de Dionísio da Trácia (1.5). Propomos em (1.6) uma síntese do conceito de frase elaborada a partir do que encontramos nas especulações acerca do lógos e em (1.7) uma caracterização do Horizonte de Retrospecção de Mattoso Câmara a partir da ideia que ele faz do pensamento linguístico da Antiguidade.

\subsection{Pensamento e lógos: as questões da linguagem em Heráclito e Parmênides}

O pensamento linguístico ocidental surge no contexto da filosofia grega (CÂMARA JR., 1986; DESBORDES, 1989; SWIGGERS, 1997; LAW, 2003). No entanto, os primeiros testemunhos do espírito grego revelam o pensamento ligado a crenças míticas; e mesmo quando em lugar do mito aparece a filosofia, o pensar que criticamente ordena e comprova, e portanto se confronta o esforço racional e autônomo 
de cada um dos indivíduos, com a crença e a tradição da sociedade, só gradualmente a atitude mítica se esvai. De certo modo, poder-se-ia designar o curso inteiro da filosofia e da ciência ocidentais como uma passagem progressiva do mito para o lógos $^{12}$ (WILPERT, 1969, p. 67).

Quanto à presença de uma reflexão sobre a frase neste período Pagliaro (1967, p. 282) sugere que:

Os pensadores gregos mais antigos, quer Heraclito, quer Parménides, perante cuja mentalidade arcaica a realidade se apresentava ainda no seu aspecto concreto, discutiram acerca da validade cognoscitiva da frase, na qual se traduz a representação, e não acerca da validade do "nome" como erroneamente se julga.

A despeito do caráter formal que irá adquirir, muito tempo depois, na Téchne, o pensamento linguístico em seus primórdios teria, assim, um fundamento mítico. De acordo com HUISMAN (2004, p. 485) em quase todos os fragmentos, daqueles que chegaram até nós da obra de Heráclito (ap. 535 a.C. - 475 a.C.), em que figura lógos, lógos é o discurso, é o dizer, é a fala: ao discurso sábio opõem-se os discursos dos seres humanos adormecidos (salvo em B 31, em que lógos é relação ou proporção), e legein é dizer.

Em Heráclito encontra-se também, possivelmente, a origem da dialética (WILPERT, 1969, pp. 71-2), sobretudo, a partir de suas proposições sobre a unidade dos contrários. Cada coisa encerra, em si mesma, o seu contrário; a sua essência abrange, ao mesmo tempo a sua negação; consiste mesmo, essencialmente, apenas na tensão simultânea e na oposição dos contrários (idem, p. 71). Ambos aspectos do pensamento heraclitiano, lógos como fala e unidade tensional, são, a nosso ver, traços daquilo que Pagliaro (1969, p. 282) chama de "validade cognoscitiva da frase" no contexto arcaico ${ }^{13}$ do pensamento filosófico grego.

\footnotetext{
${ }^{12}$ Lógos aqui aparece em sua acepção de pensamento racional. Mora (2004, p. 1795): “Além de um dizer (e de um 'dizer inteligível' e 'raciocinado'), entende-se por 'logos' o princípio inteligível do dizer, a razão enquanto 'razão universal', que é ao mesmo tempo a 'lei' de todas as coisas" e outras acepções do termo "logos" no âmbito da filosofia. Ver também GRAFFI (s/d): o autor apresenta um levantamento das traduções do termo lógos presente no capítulo 20 da poética de Aristóteles: "94 translations have been taken in account, from the end of the 13th century until the beginning of the present one: 13 of them are Latin translations, 20 Italian, 17 French, 27 English, and 17 German”.

${ }^{13}$ Arcaico e Clássico não refletem aqui nenhum julgamento de valor. Foram tomados como designativos dos períodos da história da filosofia grega. Ver WILPERT (1969): Época arcaica e época clássica.
} 
Outro traço advindo do pensamento do período arcaico e ligado à ideia de frase encontra-se em Parmênides (530 a.C. - 460 a.C.) que, com agudeza, distinguiu percepção e pensamento. Aquela abandona-se à aparência e conduz apenas à opinião. Só o pensamento capta a verdade (WILPERT, 1969, p. 73). Não será invertendo as proposições de todas as formas desejadas que extrairemos a verdade. Esse é o cânone do discurso verdadeiro, caucionado pelo real (HUISMAN, 2004, p. 746). A opinião (doxa) quando oposta à Verdade absoluta aparece como afirmação verossímil e somente verossímil: é um conhecimento de segunda ordem, aleatório, com o qual só podemos nos contentar na falta de algo melhor. Mas doxa pode, do mesmo modo, designar uma afirmação muito apropriada à crença. A percepção conduzindo à opinião e o pensamento à Verdade são os traços que complementam, a nosso ver, a ideia da "validade cognoscitiva da frase" no âmbito dos pensadores da época arcaica da filosofia grega.

Argumenta Pagliaro (s/d, p. 4) que em essência, nestes dois pensadores, que são os primeiros a pôr o problema do universo como um problema do conhecimento humano e a ver a estrutura do discurso em função de tal conhecimento e de tal problema, encontra-se a discussão da validade da representação, na qual a intuição se objetiva de acordo com as modalidades do lógos, palavra ou pensamento.

Eles olham, portanto, continua Pagliaro (ibid.), para o elo entre o discurso e a questão, que será discutida longamente, sobre a validade do nome (onoma), ou seja, se há ou não uma relação natural de necessidade entre o som e o significado. Conclui Pagliaro (ibid.), não ser desprovido de significado o fato de que o pensamento grego tenha em seus primórdios se encontrado com a frase mais que com o signo, quase que a testemunhar a prioridade dela, a frase, como unidade significativa.

\subsection{O marco inicial: Platão e sua Teoria do Lógos}

Foi com Platão (428/427 - 348/347 a.C.), definitivamente, que o aspecto material e linguístico do lógos tornou-se objeto de teorização. O diálogo em que há a fundação platônica do enunciado (ILDEFONSE, 1997, p. 57), ou igualmente, em que foram 
colocados os primeiros elementos da noção de proposição (AUROUX, 2008, p. 16) é o Sofista.

Costuma-se atribuir ao Crátilo o status de obra maior em matéria linguística no corpus platônico; Ildefonse (1997, p. 54), no entanto, sugere que ele constitui não mais que uma introdução crítica ao texto fundador nesta matéria que vem a ser o Sofista. As questões linguísticas tratadas no Crátilo são: a prioridade linguística do nome, ou seja, a problemática da nominalização, e a interrogação sobre a origem da linguagem; ambos temas sofísticos (ILDEFONSE, 1997, p. 54). É, portanto, como resposta a posicionamentos sofísticos que Platão desenvolve sua teoria da linguagem. Este diálogo, embora a correção dos nomes constitua seu objeto declarado, mais parece, nas palavras de Ildefonse (1997, p. 54) “une machinerie destinée à nous désespérer des noms et à nous détourner de la problématique sofistique du nom ${ }^{14}$."

A abertura para a fundação posterior de uma nova acepção do lógos adveio da resposta platônica às teses naturalista e convencionalista da origem dos nomes, ou melhor dito, "Platão rejeita a própria oposição como sendo inadequada e sem sentido, exigindo assim, de forma implícita, uma mudança radical da questão" (COSERIU, 2010, p. 29). A conclusão do diálogo não é outra, de acordo com Ildefonse (1997, p. 54), que o retorno à questão das formas. Na síntese lapidar deste historiador o argumento se apresenta desta forma: "C'est de l'existence des formes en effet que dépend la possibilite de l'appelation puisque c'est d'elle que dépend la stabilité minimale de toute réalité ${ }^{15}$ " (ibid., p. 54). A rejeição da questão e a compreensão da forma como meio de estabilidade da realidade geram a necessidade de fundação de uma nova ordem baseada no tratamento do "dizer verdadeiro" e do "dizer falso". É a partir deste ponto que a discussão ressurgirá no Sofista.

Para a leitura do Sofista Ildefonse (1997, p. 57) destaca que, previamente, é preciso sublinhar três pontos: o primeiro é o aspecto propriamente inovador do diálogo, a saber, que ele salva a filosofia ao mesmo tempo que funda o lógos - o individualismo e relativismo dos sofistas ameaçavam a filosofia na medida em que tendiam ao ateísmo, à imoralidade e à anarquia (BECKER, 1980, p. 138), posturas que iam contra o projeto

\footnotetext{
14 Traduzimos: "uma maquinaria destinada a fazer-nos duvidar dos nomes e a nos desviar da problemática sofista do nome".

15 Traduzimos: “A possibilidade de nomeação depende da existência das formas, visto que dela depende a estabilidade mínima de toda realidade'.
} 
de reforma social de Platão preconizados, sobretudo, em sua obra A República. De modo a fazer-lhes frente, Platão coloca a questão do não-ser como garantia da existência da falsidade, deste modo contribuindo para o desenvolvimento de um novo movimento filosófico, baseado na convicção de que há uma verdade real e há, portanto, padrões absolutos de certeza (BECKER, 1980, p. 138); em segundo lugar o Sofista constitui uma renovação positiva, científica do Crátilo - o que marca tal guinada científica é a presença do ser e do não-ser no enunciado; refletindo, de certo modo, a questão do um e do múltiplo tanto no lógos quanto no inteligível, "la cellule d'expression des réalités

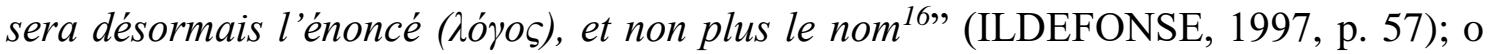
terceiro ponto é a nova concepção de lógos elaborada aí como uma muralha que a filosofia edifica contra o perigo sofista - apesar de longo, o trecho a seguir revela-nos, a partir da leitura de Ildefonse (ibid., p. 57), qual esta concepção e como ela se formou:

\begin{abstract}
C'est dans le caractère propositionnel de l'expression que la distinction entre nom et verbe pourra être reprise, comme la division logique, non réelle, du lógos premier en ses constituants; le nom aura alors changé de statut par rapport à la fonction que lui réservait Antisthène. Ce qui fonde le lógos comme structure initiale, c'est l'entrelacement (...) des formes, dont je chercherai à montrer le double caractère, syntaxique et intelligible. Enfin, il faudra considérer - et c'est ce qui justifie le titre même du dialogue - que cette fondation inouie du lógos, que le Sophiste opère par la mise en place du mélange des genres, est la muraille que la philosophie édifie contre le danger sophistique: fonder le lógos, c'est également et immédiatement fonder le lógos faux, c'est-à-dire fonder le lógos dans sa double spécificité irréductible de vérité et de fausseté ${ }^{17}$.
\end{abstract}

A atenção do filósofo, portanto, deve se concentrar sobre o lógos, pois nele encontra-se a expressão da realidade; mais especificamente em seu caráter formal, como a "célula mais reduzida que podemos considerar"; é também em seu caráter proposicional que a distinção entre nome e verbo pode ser colocada, na medida em que de per si não são nem verdadeiros nem falsos; então é do entrelaçamento destes

\footnotetext{
${ }^{16}$ Traduzimos: a célula de expressão das realidades será doravante o enunciado e não mais o nome”.

17 Traduzimos: "É no caráter proposicional da expressão que a distinção entre nome e verbo pode ser retomada, como a divisão lógica, não real, do lógos primário em seus constituintes; o nome terá então mudado de status em relação a função que Antistenes lhe tinha reservado. O que inaugura o lógos como estrutura inicial é o entrelaçamento (...) das formas, de que procurarei mostrar o caráter duplo, sintático e inteligível. Enfim, cumpre considerar - e é o que justifica o título mesmo do diálogo - que esta extraordinária fundação do logos, realizada pelo Sofista ao colocar em prática a mistura de gêneros, é a muralha que a filosofia edifica contra o perigo sofista: fundar o lógos é, igual e imediatamente, fundar o lógos falso, isto é, fundar o lógos em sua dupla e irredutível especificidade de verdade e falsidade".
} 
elementos que surge o lógos como estrutura inicial dotada de um duplo caráter, sintático e inteligível. O valor epistemológico desta "invenção" platônica para a filosofia encontra-se na dupla especificidade, ambas irredutíveis, do lógos, a saber, a verdade e a falsidade, o que permitiu suplantar o relativismo sofista e promover a emergência da lógica aristotélica.

Auroux (2009, p. 12) defende que jamais se reconhecerá suficientemente a importância do "teorema de Platão"18 presente no Sofista; considera também que este teorema é essencial para a definição da linguagem humana. Auroux (ibid.) interpreta tal teorema da seguinte forma: só existe linguagem se houver lógos, em outros termos, frase ou proposição: uma lista de signos não é linguagem. E mais: essa entidade é composta de, pelo menos, dois elementos distintos, onoma e rhema, ou seja, aquilo que se diz e aquilo que se diz daquilo que é dito. Isso significa que a comunicação do tipo "linguagem humana" é veiculada pela proposição, entidade composta de unidades categorizadas por seu papel no seio dessa mesma proposição. Ele designa uma propriedade puramente linguística, ou seja, não dedutível do fato de esse ou aquele signo designar isso ou aquilo.

\subsection{Ampliando o marco inicial: Aristóteles e a Teoria dos Quatro Discursos}

Carvalho (2013), em seu Aristóteles em nova perspectiva, propõe o que ele chama de Teoria dos Quatro Discursos; esta teoria, em linhas gerais, defende que o discurso humano é uma potência única, que se atualiza de quatro maneiras diversas: a poética, a retórica, a dialética e a analítica (lógica). Para Carvalho (ibid., p. 21) a ideia da unidade das quatro ciências aí pressupostas está embutida nas obras de Aristóteles como uma ideia medular, a despeito de ter escapado à percepção de quase todos os seus leitores e comentaristas, da Antiguidade até hoje ${ }^{19}$.

\footnotetext{
18 PLATÃO apud AUROUX (2009, p. 11): "Nomes isoladamente enunciados, termo a termo, jamais produzem um discurso (logos), assim como não o produzem verbos enunciados sem o acompanhamento de algum nome (326 a)".

19 Dois autores perceberam esta ideia e a anotaram, ainda que de passagem; são eles: Avicena e Sto Tomás de Aquino (CARVALHO, 2013, p. 21).
} 
A tese de Carvalho ${ }^{20}$ é de que a edição póstuma da obra de Aristóteles por Andrônico de Rodes, não considerou a Poética e a Retórica como obras sobre a teoria do discurso e as colocou sob o rótulo de técnica, separando-as do Organon, conjunto das obras lógicas ou introdutórias (ibid. pp. 25-6), isso fez com que deixássemos de ver o conjunto, o edifício do saber científico aristotélico, qual seja: um discurso é lógico ou dialético, poético ou retórico, não em si mesmo e por sua mera estrutura interna, mas pelo objetivo a que tende em seu conjunto, pelo propósito humano que visa a realizar (CARVALHO, 2013, p. 22)". Tal tese propõe, assim, que a tradição reconsidere a organização das obras do estagirita de modo a colocar a Poética e a Retórica como partes do Organon. Tese semelhante ${ }^{21}$ encontra-se em Guido Morpurgo-Tagliabue (1967, p. 13) que diz "Infatti le considerazioni di Aristotele sul linguaggio risultano ripartite, di massima, in due settori, e fanno capo a due gruppi di scritti diversi: il settore lingua-pensiero all'Organon, e in particolare al De interpretatione; il settore língua-stile alla Poetica e alla Retorica ${ }^{22}$ ".

$\mathrm{Na}$ esteira destas reflexões, poderíamos aventar a hipótese de que, ao tomarmos a frase como unidade do discurso (CÂMARA, 1974, p. 162), haveria nos tratados aristotélicos sobre questões ligadas à linguagem considerações sobre particularidades da frase, vista como "célula mais reduzida" (ILDEFONSE, 1997, p. 57) da expressão linguística. Segundo Lamas (2007, p. 167. Nota 29) para Aristóteles a linguagem é essencialmente lógos semântico, isto é, conteúdo significativo, mas se manifesta de três modos diferentes: como lógos apofântico (como linguagem que diz o verdadeiro e o falso), como lógos poético (como linguagem que cria um mundo autônomo, regido por uma necessidade interna) e como lógos pragmático (como linguagem usada para os fins práticos da vida). A cada uma destas modalidades da linguagem o Estagirita dedica um tratado: Poética, Retórica e Da Interpretação. Carvalho (2013), como vimos, inclui nesta perspectiva a dialética, à qual Aristóteles dedicou-se no tratado Tópicos.

\footnotetext{
20 Todo este parágrafo foi sugerido pelo professor Jorge Viana de Moraes, a quem agradeço, em sua avaliação desta dissertação.

${ }^{21}$ A diferença entre as duas propostas é a de que Carvalho está mais interessado numa teoria do discurso em seu aspecto cognoscitivo e Morpurgo-Tagliabuo investiga a teoria linguística aristotélica.

22 Traduzimos: "De fato, as considerações de Aristóteles sobre a linguagem parecem dividir-se, em princípio, em dois setores, e referem-se a dois grupos de diferentes escritos: o setor linguagempensamento no Organon e, em particular, no De interpretatione; o setor linguagem-estilo na Poética e Retórica."
} 
Nos tratados Poética e Retórica os termos de base são léxis e lógos, ou seja, elocução e proposição, nos tratados Da Interpretação e Tópicos os termos são apofansis e lógos, declaração e discurso. A necessidade de subsistir o ser verdadeiro e o ser falso é atribuída tanto aos sons pronunciados quanto ao pensamento. Este está presente na alma sob duas formas:

Há, por conseguinte, na alma, tanto o pensamento sem o ser falso ou o ser verdadeiro, quanto o pensamento em que é necessário que subsista um ou outro desses, e da mesma maneira em relação aos sons pronunciados $(D a$ Interpretação, 16a).

O pensamento de primeiro tipo se evidencia a partir dos nomes e dos verbos em si; já o de segundo tipo é expresso pela declaração.

No Da Interpretação, lógos é definido como "som articulado e significativo", muito próximo da definição que encontramos na Poética, onde também há a menção ao valor significativo das partes; Aristóteles insere naquele tratado, no entanto, dois modos de ser significativo: ou como expressão ou como afirmação/negação. As partes da proposição só podem ser significativas no primeiro modo. Os discursos [proposições] são todos significativos, não como ferramenta ${ }^{23}$, mas, por convenção (Da Interpretação, 16b). A ideia de "por convenção" fora esclarecida anteriormente como querendo dizer que "nada por natureza pertence aos nomes, mas vem a pertencer quando se torna símbolo, uma vez que mesmo os sons inarticulados, como os das feras, revelam algum significado, ainda que nenhum deles seja um nome" (Da Interpretação, 16a). O valor significativo da linguagem, podemos supor, estaria então subordinado ao processo de simbolização, que por sua vez está sujeito à intencionalidade do emissor. Neste ponto, Aristóteles se afasta da tese apresentada no Crátilo quanto ao valor instrumental da linguagem.

O discurso declaratório (lógos apofântico) caracteriza-se por ser, basicamente, afirmação ou negação. Seu traço formal é decorrer do verbo ou de um de seus casos ( $D a$ Interpretação, 17a). Dois outros aspectos importantes da frase declaratória são: "ou expressa uma única coisa, ou é um pela conjunção" (Da Interpretação, 17a), este último

\footnotetext{
${ }^{23}$ Órganon - a palavra grega que traduz instrumento, ferramenta. Aristóteles se afasta da tese de Platão,
} do Crátilo (MATA, 2013, p. 51). 
tipo gera os discursos múltiplos que se subdividem em "que expressam muitas coisas" e "assindéticos" (sem profunda conexão entre as substâncias; o múltiplo); o outro aspecto importante advém daquilo que a compõe: "uma parte é declaração simples (...) a outra parte é a composição destas últimas (coisas) (Da Interpretação, 17a)". Não nos esqueçamos de que a estas definições subjaz um forte elemento supralinguístico, na medida em que o esforço de elaboração do tratado está voltado para um tipo especializado de raciocinar de modo a alcançar um conhecimento filosófico positivo. Por fim, Aristóteles resume o conceito de discurso declaratório: "E é a simples declaração com som articulado e significativo a respeito do seguinte: se alguma coisa subsiste ou não subsiste [em outra coisa] conforme os intervalos de tempo" ( $D a$ Interpretação, 17a). Em seguida há a apresentação das especificações da lógica modal; assunto, por fim, do tratado Da Interpretação.

No Tópicos encontramos a conceituação, dentre os predicáveis, do enunciado que explicita o que cada coisa é, a saber, da definição. Não é ela uma proposição tomada em si, mas é a partir dela que são formuladas não só as proposições, mas também os problemas que serão objeto do raciocínio dialético. Tal enunciado pode surgir como um enunciado usado em lugar de um nome ou no lugar de outro enunciado (Tópicos, 102a).

\subsection{Indo mais além: os estoicos e o estudo dos lekta}

O estoicismo foi uma escola filosófica grega e greco-romana que influenciou largamente o pensamento ocidental. Para Mora (2005, p. 912) o estoicismo tem sido uma "constante histórica" no pensamento ocidental. É não só um conjunto de doutrinas filosóficas, mas também um modo de vida e uma concepção de mundo. Quanto à linguagem, podemos afirmar a importância de suas especulações para o posterior desenvolvimento da gramática como ciência da linguagem.

A reconstrução do pensamento linguístico dos estoicos é considerada tarefa difícil, dado que só dispomos de fragmentos recolhidos por autores, geralmente, hostis aos estoicos. Todorov (2014, p. 22) aponta que o fragmento mais importante a este respeito encontra-se em Sexto Empírico, em Contra os matemáticos, VIII, 11-12: 
Dizem os estoicos que três coisas estão ligadas: o significado, o significante e o objeto. Dessas coisas, o significante é o som, por exemplo, "Dion"; o significado é a coisa mesma que é revelada e que apreendemos como subsistente na dependência do nosso pensamento, mas que os bárbaros não compreendem, embora sejam capazes de ouvir a palavra pronunciada; ao passo que o objeto é o que existe no exterior: por exemplo, Dion em pessoa. Duas dessas coisas são corporais: o som e o objeto, enquanto uma é incorporal, a entidade que é significada, o dizível (lekton), que é verdadeiro ou falso.

Este esquema da semiose linguística reflete o forte conceitualismo estoico que será, em contraste com o realismo platônico e aristotélico, o caminho que levará a consideração da linguagem como um fenômeno em si, independente das especulações cognoscitivas originárias, pela gramática e pela filologia da escola de Alexandria. Wilpert (1969, p. 105) destaca este conceitualismo como segue:

\begin{abstract}
Em oposição ao realismo platónico do conceito, que fazia corresponder ao conceito geral um objeto adequado na Ideia e, em oposição ao realismo aristotélico mitigado, para o qual a essência serve de correspondência ao conceito, encontramos na doutrina estoica um conceptualismo que, à unidade do conceito não faz corresponder unidade alguma na esfera do objeto, mas atribui ao conceito uma função unificadora.
\end{abstract}

Alan Rey (1973, p. 30 apud NEVES, 2005, p. 91) ilustra, com o esquema a seguir, a economia da semântica estoica ${ }^{24}$ :

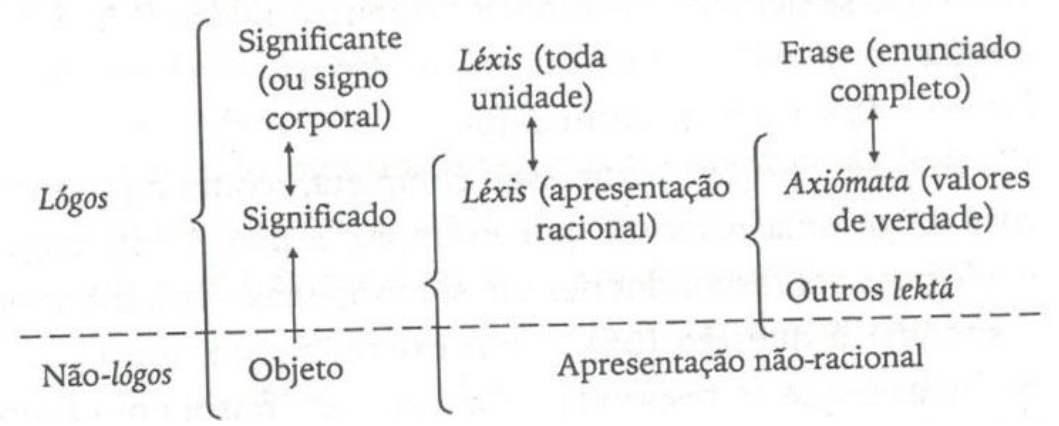

FIGURA 1 Economia da semântica estoica segundo REY (1973 apud NEVES, 2005)

O significante, a voz, é o meio para manifestar o significado, o lékton. O lékton é, pois, o que há de espiritual no som, aquilo que é designado por ele, que não é, porém,

\footnotetext{
${ }^{24}$ Para uma explanação completa deste esquema ver o capítulo 5 da parte I de NEVES (2005).
} 
simplesmente a representação que o objeto da percepção provoca na mente (phantasía). O lékton corresponde a uma "apresentação" das coisas por meio da linguagem; é aquilo que está no som significante, tendo o mesmo conteúdo da representação mental, sem ser, porém, a mesma coisa que a impressão produzida na alma pelo objeto. Ele é, pois, o significado a que o som remete, diferente, segundo o modo de existência, tanto do objeto como da representação mental. Os estoicos concebem que não são, pois, os seres individuais que são objeto do pensamento discursivo, mas os eventos, os fatos e a relação entre eles; esses são os lektá (NEVES, 2005).

A percepção, por parte dos estoicos, de mais esta dimensão do ato linguístico, a saber, os significados linguísticos, ao lado dos referentes extralinguísticos e da materialidade linguística tem, a nosso ver, muito a contribuir para uma teorização da frase que dê conta de seu caráter heteróclito. A frase estando no limiar da língua e do discurso, entre o caráter permanente do sistema e o efêmero do ato linguístico carece de uma concepção que abarque ambos os aspectos de sua constituição, holístico e analítico, numa síntese eficaz tanto do ponto de vista descritivo quanto produtivo.

A classificação dos lektá é, na verdade, uma caracterização com base nos significados, a qual reverte, porém, por assim dizer, numa classificação dos enunciados significantes (NEVES, 2005, p. 92). A divisão estoica dos lektá não é conhecida com certeza, mas Bochenski (1966, p. 68 apud NEVES, 2005, p. 91), reproduz a divisão de B. Mates, julgando que é a mais correspondente à doutrina estoica original:

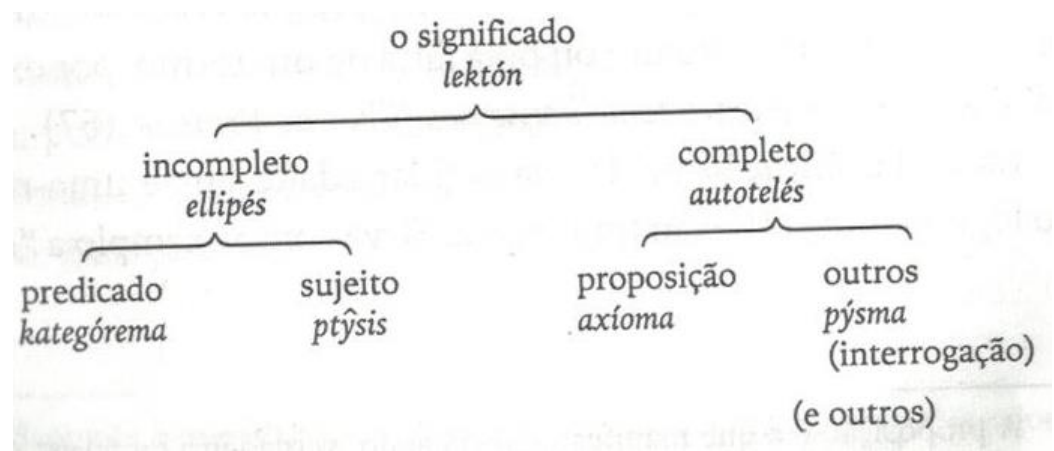

FIGURA 2 Divisão estoica dos lektá a partir de Bochenski (1966 apud NEVES, 2005)

Esta classificação, bastante econômica, a despeito de tratar dos significados, implica também considerações de cunho formal. A proposição identifica-se com o lektón expresso de modo completo, tem em si a propriedade exclusiva de ser verdadeiro 
ou falso, o que o difere formalmente do predicado, um lektón incompleto, e da questão, que é um lektón completo, mas que exige uma resposta.

A partir da exposição de NEVES (2005, pp. 92-6) organizamos o quadro a seguir com a classificação dos enunciados significantes:

\begin{tabular}{|c|c|}
\hline ENUNCIADO SIGNIFICANTE & CARACTERÍSTICA \\
\hline Proposição & Verdadeiro / Falso \\
\hline Questão & Exige uma resposta \\
\hline Interrogação & $\begin{array}{c}\text { Necessidade de uma frase como } \\
\text { resposta }\end{array}$ \\
\hline Imperativo & Comando \\
\hline Juramento & $\begin{array}{c}\text { Faz alguém intervir } \\
\text { favoravelmente? }\end{array}$ \\
\hline Imprecação & $* * *$ \\
\hline Sugestão & $* * *$ \\
\hline Vocativo & $* * *$ \\
\hline "O que é semelhante à proposição" & Acréscimo ou falta de um termo \\
\hline QUADRO 1: Esquema parcial da classificação estoica dos enunciados significantes
\end{tabular}

Para Neves (ibid., p. 92) esta classificação evidencia solidariedade entre uma reflexão lógica e uma reflexão linguística. Ainda outras classificações foram elaboradas: proposições simples e não-simples; dos enunciados proposicionais, isto é, das formas linguísticas das proposições, v. proposições simples (negativa, privativa, afirmativa, indicativa e indefinida); das proposições não-simples através das relações expressas por meio de formas de linguagem (relações de implicação; de inferência; de conjunção; de disjunção; de causa; de comparação).

Na perspectiva estoica, o discurso linguístico é metalíngua do discurso natural, é linguagem de uma linguagem das coisas. Há um discurso linguístico que coincide com um discurso natural. Num e noutro, há significante e significado, e entre ambos há uma relação de significante (discurso linguístico) e significado (discurso natural). Os estoicos descobriram, pois, um significante na própria natureza, estendendo, assim, para além da linguagem, a relação significativa (NEVES, 2005, p. 96). 


\subsection{Nasce a gramaticologia ocidental: a Escola de Alexandria}

Antes de Dionísio da Trácia (170 a.C. - 90 a.C.), a gramática achava-se implícita nas práticas e na mente dos filólogos. Aristarco, mestre de Dionísio na escola filológica de Alexandria, já havia feito várias distinções entre gramática, prosódia, métrica etc. Dionísio classificou todas estas distinções e deu origem àquela teoria ou técnica que se chama gramática, da qual, na opinião de Righi (1969), a humanidade parece não poder prescindir na aprendizagem das diversas línguas.

Borges (2012, p. 88) chama de gramática tradicional a esta teoria das línguas humanas surgida na Antiguidade Clássica e que se mantém essencialmente igual até os nossos dias, dando forma às gramáticas escolares, por exemplo. Essa teoria tem sua formulação completada já na Idade Média e é base do pensamento sobre as línguas humanas em, pelo menos, todo o mundo ocidental.

O que deu origem à gramática tradicional foram as análises, filosóficas e retóricas, dos discursos; o que, para Swiggers (1997, p. 10) explica seu apego às unidades discursivas diretamente localizáveis na fala (e, mais tarde, desde que se começou a abandonar a scriptio continua, na escrita), ou seja, as palavras.

O contexto mental em que se deu esta origem é o chamado período helenístico. Assegura-nos Neves (2005, p. 111) que a disciplina gramatical é uma criação da época helenística, a qual representa, em relação à época helênica, não apenas uma diferença de organização política e social, mas também o estabelecimento de um novo estilo de vida, um novo ideal de cultura. Especialmente, verifica-se um esforço de pesquisa; reflete-se e exerce-se crítica sobre tudo o que ficara de séculos de criatividade. A atividade cultural se concentra nas bibliotecas e tem em vista primordialmente a preservação, para transmissão, da herança cultural helênica.

Na perspectiva da história da filologia, pode-se dizer com Righi (1969, p. 59) que com Dionísio a escola filológica alexandrina esgotou-se, assim como com o inventário da retórica e da poética aristotélicas cessaram as grandes personalidades criadoras da literatura grega; no entanto, na perspectiva do pensamento linguístico ocidental, a história só estava em seu início. 
A definição de frase presente na Téchne Grammatiké de Dionísio da Trácia reflete tanto o contexto cultural quanto as ideias linguísticas que então vigoravam:

\begin{abstract}
Palavra é a menor parte de uma frase bem constituída. Frase é um grupamento ordenado/composição de palavras em prosa que manifesta um pensamento completo. A frase tem oito partes: nome, verbo, participio, artigo, pronome, preposição, advérbio, conjunção. $\mathrm{O}$ apelativo surge como uma das espécies de nomes. (tradução de CHAPANSKI, 2003, p. 26)
\end{abstract}

Encontra-se aí tanto o apoio na palavra como unidade significativa básica quanto a indicação do viés de que parte, o filológico (prosa). A definição de frase propriamente dita, "Frase é um grupamento ordenado/composição de palavras em prosa que manifesta um pensamento completo", ainda hoje ecoa em muitas gramáticas escolares. A ideia de "pensamento completo" continua como causa de muitos embaraços, como podemos ver com Hauy (1983). Mattoso (1974), apoiando-se em Gardiner (1932) já apontava a melhor solução para tais embaraços: o termo autoteles a partir do qual forjou-se, por meio de sua tradução, a ideia de "pensamento completo" indica, mais propriamente, "um funcionamento autônomo no intercambio social". Swiggers (1997, p. 32) vê na definição de frase de Dionísio da Trácia um dos dois lugares ${ }^{25}$ em que se manifesta a visão hermenêutica da linguagem - "une visée globale sur la nature et la fonction du langage ${ }^{26 "}$ - que remete à concepção da linguagem exposta no tratado Peri Hermeneias de Aristóteles. De acordo com Swiggers (ibid.) a teoria aristotélica da "semiose" linguística compreende três elementos: a linguagem, as afecções da alma e a realidade. Desta forma, na definição de lógos, Dionísio afirma a ligação entre uma expressão linguística e os conteúdos do pensamento que ela simboliza (id. ibid., p.33).

Quanto à noção de "completude", Swiggers (1997, p. 33) afirma que é um reflexo da distinção estoica entre lektá completa e lektá incompleta; a passagem em questão da Téchne é também interessante pela associação que faz entre o domínio da léxis e o domínio da dianóia ${ }^{27}$, termos utilizados por Aristóteles em sua Poética para designar dois dos seis componentes da tragédia: o que está em palavras e o pensamento.

\footnotetext{
${ }^{25} \mathrm{O}$ outro lugar é a passagem em que Dionísio define nome.

26 Traduzimos: "um olhar global sobre a natureza e a função da linguagem”.

27 MORA (2004, p. 729): “Desde Platão, foi comum na filosofia grega usar dianóia para designar o pensamento discursivo, o pensar que procede por raciocínio, ao contrário de (...) noesis, entendida como pensamento intuitivo, isto é, como captação intelectual imediata da realidade (inteligível)".
} 
É ao domínio da léxis que Aristóteles atribui os tipos de discurso, os micro e macroconstituintes da frase e, também, o lógos, enquanto combinação de palavras. O domínio daquilo que é expresso pelas palavras é a dianóia; compreende também os usos argumentativos, afetivos e emotivos da linguagem. Aristóteles atribui este domínio à Retórica. Onde o Estagirita separa os dois domínios, a Téchne evidencia sua relação semiótica: a léxis é a face significante da dianóia. Swiggers (ibid., p. 34) conclui que quanto a definição de lógos, "la Tékhne esquisse donc, de façon originale, une doctrine sur la nature et la fonction du lógos ${ }^{28}$ ".

\subsection{A FRASE na Antiguidade: Resultados "arqueológicos"29"}

Esta breve recolha de evidências da presença da ideia de FRASE na Antiguidade Clássica, ainda que não suficientemente abrangente, revela-nos o importante papel que sua formulação desempenhou em diversos âmbitos do saber, não só linguísticos, mas também epistemológicos. Não nos esqueçamos que sua emergência se deu a partir de especulações sobre a representação do saber e sobre seu valor (verdadeiro/falso); só muito depois a ideia de frase emergiu no âmbito restrito do puramente linguístico.

À questão "O que é a frase na Antiguidade?" poderíamos responder, com base em tais conceitos, que é a manifestação, ou melhor, a enunciação do lógos; em tal resposta, no entanto, deve estar suposto o caráter de representação percebido por Heráclito e Parmênides, em seus desdobramentos de unidade tensional de contrários (Heráclito) e de divisão entre opinião e verdade (Parmênides); nesta perspectiva a frase é a unidade significativa. Também o caráter formal percebido por Platão, para quem é a forma o que permite a estabilidade mínima de toda a realidade; o entrelaçamento das formas (onoma e rema) gera a estrutura inicial que é o lógos. A frase é, nesta perspectiva, a unidade da expressão da realidade. Com Aristóteles e os estoicos é o caráter semântico da linguagem que informa a concepção de frase, seja ligada ao

\footnotetext{
${ }^{28}$ Traduzimos: "a Téchne esboça assim, de maneira original, uma doutrina sobre a natureza e a função do lógos".

${ }^{29} \mathrm{O}$ uso da palavra "arqueológico" aqui não remete ao conceito foucaultiano de arqueologia, ou seja, ao "exame do 'quadro' que forma uma 'história geral' (que difere de uma 'história global') (MOTA, 2004, p. 194)", mas simplesmente a uma metáfora que tem por base o sentido "estudo das coisas antigas (AULETE, 2011, 69)".
} 
ambiente discursivo no qual se efetivam (apofântico, poético, pragmático e dialético) no primeiro, seja na depreensão do dizível (lektá) como elemento relevante no esquema semiótico dos segundos. Há com Dionísio da Trácia uma resposta doutrinária às questões até então latentes: a frase é unidade de formas e de conteúdo, com funcionamento autônomo no intercâmbio social.

\subsection{A Antiguidade Clássica no Horizonte de Retrospecção de Mattoso Câmara}

\subsubsection{O conceito de Horizonte de Retrospecção}

O conceito de horizonte de retrospecção, HR, é apresentado e discutido, dentre outros, em AUROUX (1986, 1999, 2006). O conceito designava, inicialmente, apenas o conjunto de referências a trabalhos anteriores, presente como conteúdo no discurso científico. Em outro momento, foi utilizado para designar a percepção que dado autor tinha das obras que antecediam a sua. Por fim, passou a designar, também, o conjunto de conhecimentos anteriores de que o cientista dispõe no momento de sua atuação cognitiva frente a um problema.

Este conceito emergiu da consideração de que uma "ciência" é uma pura abstração, mais ou menos justificada, do mesmo tipo que uma língua assim o é; o que de fato existe são as atividades e os produtos científicos realizados por homens que vivem e trabalham em circunstâncias determinadas (AUROUX, 1986). São estas atividades e produtos que constituem os sistemas científicos, SC.

Por outro lado, este conceito interage com a ideia de que o ato de saber (a produção de conhecimento), AS, é o objeto próprio da história da ciência, HC, porque é ele o elemento marcado por algum tipo de temporalidade; não são os conhecimentos, $\mathrm{C}$, que são datados, pois não são eventos, mas suas eventuais aparições é que são passíveis de serem datadas (AUROUX, 2006). Desta forma, podemos esquematizar as propostas de Auroux da seguinte forma:

(i) SC : HR / AS : C \} HC 
A estrutura do SC determina a estrutura do HR que, por sua vez, é um dos componentes do AS e, portanto, uma das causas da produção científica, ou seja, do C. Este complexo é, então, o fundamento de uma HC.

Para Auroux (1988) os dados factuais apontam para a confirmação da tese da independência dos quatro tipos possíveis do saber metalinguístico; também, em sua concepção, a história dos saberes linguísticos é feita justamente de seus desenvolvimentos, de suas interações, mesmo da passagem da tematização de certos fenômenos de um tipo de saber para outro.

A proposta teórica de Auroux tem por escopo as ciências da linguagem e por objeto sua história. O que pretendemos neste trabalho é abranger algo de menor escala; lidamos não com as ciências da linguagem, mas com o pensamento linguístico de dado estudioso. Para tanto, inspirados no referido esquema teórico da $\mathrm{HC}$, propomos o esquema a seguir:

(ii) EC : HR $\}$ PL \{ CE : EI

A partir das relações entre os enunciados científicos, EC, e o horizonte de retrospecção, HR, por um lado e da datação das emergências das ideias, EI, localizadas em seus respectivos contextos epistêmicos, CE, por outro, acreditamos poder inferir os contornos do pensamento linguístico, PL, do estudioso em questão.

De acordo com Auroux (2006, p. 107) um horizonte de retrospecção pode ser estruturado de várias maneiras; os conhecimentos podem figurar de maneira indistinta como conhecimentos comuns, mas também de modo indexado, com a referência explicita aos autores e às datas; pode ainda ser estruturado de modo a que a temporalidade não afete os conhecimentos, tomando-os como co-presentes. De toda forma, a existência dos horizontes de retrospecção testemunha a necessária ligação do conhecimento com o tempo.

Ao lado dos tipos de como figuram os conhecimentos, por meio dos quais configura-se o HR, observamos certa aspectualidade a partir da qual podemos caracterizar o papel que tais conhecimentos desempenham na produção de saberes. Assim, o conhecimento que aparece como indexado, muitas vezes surge embotado, ou 
seja, circunscrito à determinado contexto não mais produtivo; o conhecimento copresente, por outro lado, surge como atualizado, pois é tomado pelo estudioso como elemento ativo de seu pensar, seja como fundamentação teórica, como objeto de interlocução ou como suporte a um ponto de vista; os conhecimentos de tipo comum surgem, muitas vezes, sob o aspecto intemporal, pois são aqueles que fundamentam a área de estudos e, portanto, são tomados como pressupostos, válidos e fundamentais para a produção de saberes. A correlação entre os tipos e aspectos não é de nenhum modo absoluta, cada categoria funciona individualmente, bem como em correlação com os demais tipos. Esquematicamente, no entanto, temos:

\begin{tabular}{|c|c|}
\hline \multicolumn{2}{|c|}{ HORIZONTE DE RETROSPECÇÃO } \\
\hline \multicolumn{2}{|c|}{ Conhecimento } \\
\hline TIPO & ASPECTO \\
\hline Indexados & Embotado \\
\hline Co-presente & Atualizado \\
\hline Comum & Intemporal \\
\hline
\end{tabular}

QUADRO 2: Categorias de análise dos modos de apresentação de C em HR.

\subsubsection{O HR estruturado como saber histórico}

Os autores e conhecimentos recenseados neste capítulo aparecem na obra de Mattoso nos dois primeiros modos de estruturação (indistinto e indexado, na terminologia de Auroux). A principal obra em que aparecem é sua História da Linguística (1975). Seus capítulos foram escritos originalmente em inglês como lições para o curso que ministrou no Linguistic Institute, promovido em 1962 pela Linguistic Society of America, na Universidade de Washington. Em duas outras ocasiões Mattoso ministrou curso sobre o mesmo tema: em 1965 em Montevidéu e em 1967-1968 no México, em Institutos de Linguística promovidos pelo Programa Interamericano de Linguística e Ensino de Idiomas (PILEI) e pela Associação de Linguística e Filologia da América Latina (ALFAL).

O livro História da Linguística (1975) é um bom exemplo do desafio filológico ${ }^{30}$ em que se converteu a obra mattosiana: um plano com doutrinas sólidas e

30 A tradução feita pela professora Maria do Amparo Barbosa de Azevedo é, em muitos aspectos, meritória, no entanto, a nosso ver, falha ao utilizar o termo oração em contextos nos quais o autor 
perspectiva segura prejudicado por contingências socio-profissionais e realizado, muitas vezes, à revelia do autor, de modo apressado e sem o devido apuro crítico. Podemos ter uma boa ideia do que cada obra de Mattoso poderia ter sido ao analisarmos o cuidado e apuro com que preparou as quatro edições dos Princípios de Linguística Geral ${ }^{31}$. Mas este é assunto para outro momento.

Altman (2012, p. 17-18) afirma que até os anos 1980, só a História da Linguística, de Mattoso Câmara (1986), pôde ser citada como manual suficientemente abrangente elaborado por um linguista brasileiro. Nesse manual, de largo escopo, não há, no entanto, nenhuma referência ao contexto acadêmico brasileiro ou aos seus pesquisadores, o que a nosso ver pode sugerir, aliado à representação que Mattoso elabora dos estudos linguísticos no Brasil em suas recensões ${ }^{32}$, a concepção de que a linguística propriamente dita não era praticada no Brasil no período que sua História abrange. Efetivamente, para Mattoso, a linguística geral, fundamento da linguística propriamente dita, começa a ser estudada entre nós a partir da década de 1940. Mattoso reviu as tradições clássicas do pensamento linguístico desde a Antiguidade até a tradição estrutural sincrônica, que lhe era contemporânea, passando pela Idade Média, pelo Renascimento, pelos séculos XVI, XVII e XVIII, XIX e por grande parte do século $\mathrm{XX}$.

Do ponto de vista da retrospecção, interessa-nos, não só os autores sobre os quais Mattoso discorre em sua História, mas também a doutrina historiográfica que elabora de modo a organizar estes autores e suas ideias. Partidário, como muitos, da convicção de que a linguística como ciência surge no século XIX, propõe a partir deste marco, igualmente temporal e epistemológico, uma curiosa divisão do longo tempo dos estudos sobre a linguagem. Para Mattoso (1986, p. 13) a linguística propriamente dita é

escolheria o termo frase. Tal preferência de Mattoso fica evidente em uma versão datilografada (ver Anexo II) em português que se encontra no Acervo Mattoso Câmara Jr. da Universidade Católica de Petrópolis.

${ }^{31}$ Mattoso revisou o texto do Fonêmica com vistas a uma nova edição, que não chegou a ser publicada. No Acervo do autor, que se encontra na Biblioteca da Universidade Católica de Petrópolis, encontram-se as provas desta revisão que também são uma mostra da preocupação de Mattoso com a qualidade formal e de conteúdo de suas obras.

32 Assim começa Mattoso sua recensão intitulada A Linguística Brasileira (in Naro, 1976, p. 47): “Os estudos linguísticos no Brasil sempre se concentraram na língua portuguesa, não havendo os estudiosos brasileiros demonstrado qualquer interesse pela filologia clássica ou indo-européia, ou por qualquer discussão filosófica sobre a origem, âmbito e funções da linguagem. Absorvidos pelo português, dedicaram-se quase exclusivamente a três principais campos de interesse: a história e a filologia do português, o estabelecimento de uma língua padrão para o Brasil, e a dialetologia brasileira.” 
uma ciência muito nova. Começou a existir na Europa em princípios do século XIX sob o aspecto de um estudo histórico. Antes dessa época encontramos apenas, em sua classificação, a pré-linguística e a paralinguística na cultura ocidental.

Para chegar a esta classificação em gêneros, Mattoso (1986) elencou as seguintes espécies de estudos da linguagem:

$$
\begin{aligned}
& \text { I - O Estudo do Certo e Errado } \\
& \text { II - O Estudo da Língua Estrangeira } \\
& \text { III - O Estudo Filológico da Linguagem } \\
& \text { IV - O Estudo Lógico da Linguagem } \\
& \text { V - O Estudo Biológico da Linguagem } \\
& \text { VI - O Estudo Histórico da Linguagem } \\
& \text { VII - O Estudo Descritivo }
\end{aligned}
$$

Constituem o âmago da linguística propriamente dita os estudos VI e VII, nos quais "tomamos a linguagem como um traço cultural da sociedade e tentamos chegar à sua natureza, ou explicando sua origem e desenvolvimento através do tempo ou o seu papel e meio de funcionamento real na sociedade (CÂMARA JR., 1986, pp. 12-3)”. O estudo I "nada mais é que uma prática do comportamento linguístico (id. ibid.)", não sendo, portanto, ciência. O estudo II também não é ciência no sentido próprio do termo, ainda que apresente "alguns aspectos científicos na medida em que se baseia na observação e na comparação objetivas (id. ibid.)", no entanto, não apresenta aquilo que faz de um estudo autêntica ciência, a saber, "o verdadeiro significado dos contrastes que descobre e não desenvolve um método científico de focalizar a sua matéria (id. ibid.)", ainda que não possa dizer o mesmo do estudo III, Mattoso o inclui junto com os dois anteriores na pré-linguística porque são "algo que ainda não é linguística (id. ibid.)". Por não entrarem no domínio da linguagem propriamente dita, permanecendo em seus limites, os estudos IV e V são classificados como paralinguística. 
Este modo de pensar a estrutura histórica do pensamento linguístico é marcado por um viés fortemente cientificista, característico dos esforços de legitimação institucional de qualquer estudo na Modernidade: a ciência da linguagem é a linguística e por ciência entenda-se aquilo que "tem a configuração própria que lhe dá a experimentação e um método rigoroso de pesquisa (CÂMARA JR., 1965, in CUNHA; ALTGOTT, 2004, p.198)". Tanto assim que seu nascimento é bem marcado em princípios do século XIX com o estudo histórico da linguagem, bem como com o trabalho do "primeiro genuíno linguista do século", Wilhelm von Humboldt. Este viés cientificista restringe sobremaneira a análise que faz dos autores da Antiguidade Clássica.

A ideia que Mattoso faz do estudo da linguagem na Antiguidade Clássica está, de alguma forma, condicionada pelo posicionamento epistemológico que adota, a saber, o de que a linguística propriamente dita é aquela praticada a partir de princípios do século XIX, tanto que abre sua exposição histórica evocando não o pensamento grego, mas o sanscrítico:

Panini e Pantañjali estabeleceram as bases da gramática normativa do sânscrito e os tratados hindus que surgiram posteriormente nada mais eram que comentários sobre as "Sutras de Panini" e sobre o "Mahabhasya de Pantañjali". A orientação do "certo e do errado" baseia-se numa observação muito acurada dos sons do sânscrito e da composição do vocábulo. Tarefa semelhante foi conduzida no prakrits, isto é, os vários dialetos do Médio Hindu falado na Índia Antiga ao lado do sânscrito, uma língua escrita essencialmente para trabalhos religiosos e literários e para uso das classes superiores (CÂMARA JR., 1986, pp.15-16).

É no modelo de análise linguística sanscrítica que a linguística propriamente dita encontra seu melhor correlato em tempos remotos. É o que Mattoso (1986, p. 16) parece sugerir ao afirmar que

os estudos linguísticos permaneceram desconhecidos no Ocidente até fins do século XVIII. É por isso que não tiveram qualquer influência no desenvolvimento do estudo da linguagem antes do advento da lingüística propriamente dita, no século XIX. 
Como o conhecimento do modelo sanscrítico pelo pensamento linguístico ocidental ocorreu apenas na modernidade, a conformação deste deu-se sobre outra base, a saber, a cultura da Grécia Antiga. Diferente da cultura Indiana, cujos estudos eram mais próximo da linguística propriamente dita, a "principal abordagem ao estudo da linguagem na Grécia foi através da filosofia (CÂMARA JR., 1986, p. 16)”. A predominância do olhar filosófico sobre a linguagem, sobretudo, a partir do critério lógico como fundamento das estruturas linguísticas, será alvo de muitas críticas por parte de Mattoso ${ }^{33}$, sobretudo por sua forte influência sobre os estudos da sintaxe. Como Mattoso via, criticamente, a influência da lógica sobre a análise da linguagem, os autores vinculados a este contexto epistêmico aparecem embotados em sua exposição: são eles apenas referenciados, de modo breve e nos aspectos que contribuíram para a emergência do modelo gramatical de estudo da linguagem.

Complementam os modos de estruturação do horizonte de retrospecção que são, como vimos, os modos como os conhecimentos aparecem e atuam na produção do conhecimento, os aspectos que tais conhecimentos adquirem por força do modo como aparecem e atuam. Assim, entendemos por embotamento a presença meramente referenciada do conhecimento. É o que se dá, por exemplo, na História da Linguística com Platão, Aristóteles e os demais estudiosos greco-romanos. Os conhecimentos que ocasionaram não entram de modo ativo no Sistema Científico da linguística propriamente dita, deste modo as suas representações no discurso do autor surgem sob o aspecto do embotamento. Dois exemplos são aí emblemáticos. Vejamos a partir do enunciado “(...) Demócrito e, no seu rastro, Epicuro e seus discípulos discutiram assuntos linguísticos (CÂMARA JR., 1986, p. 16)” em que Mattoso, após referenciar a figura de Demócrito e afirmar que também ele discutiu assuntos linguísticos ao ponto de constituir uma corrente com base em seu pensamento, não referencia igualmente qual a substância deste pensamento. O mais próximo que nos oferece desta necessária

\footnotetext{
${ }^{33}$ Eis um exemplo do tom e da configuração de tais críticas: “(...) a análise que se pratica é em bases estritamente lógicas, o que decorre da maneira por que se iniciou e se constituiu na velha Grécia como uma exegese da frase para fins filosóficos. Parte-se do pressuposto de que a lógica abarca em sua totalidade a expressão linguística, ou seja, que a expressão linguística só se faz na base de um raciocínio explícito, qual o depreendeu a lógica aristotélica examinando aquela pequena parcela de frases em que isso realmente se dá. Criou-se assim um círculo vicioso muito pouco lógico: de uma parte da expressão linguística tirou-se uma teoria de expressão lógica e projetou-se essa teoria sobre toda a expressão linguística. A única reação contra esse insatisfatório estado de coisas foi a de substituir a denominação "análise lógica" por "análise sintática", à maneira daquele personagem de Machado de Assis que mudava de vez em quando o nome de batismo do seu criado para ter a impressão de que mudara de criado (CÂMARA Jr., 1975 [1960], pp. 63-4).
} 
referência é dizer-nos que "Aristóteles desenvolveu uma teoria lingüística baseada nas idéias de Demócrito (CÂMARA JR., 1986, p. 16)".

Mesmo a teoria linguística de Aristóteles aparece circunscrita aos seus resultados gramaticais; também aí situa a Escola Estoica:

Por outro lado, como filosofia (principalmente Aristóteles e os Estóicos), desenvolveram uma análise mais completa da linguagem e chegaram às asserções gramaticais, dando lugar a um debate referente à natureza da gramática, isto é, das regras subjacentes que existem no uso da linguagem (idem, p. 18).

A partir de ambos os dois adquirem uma permanência ou identidade (Auroux, 2006) duas correntes de pensamento, a analogista e a anomalista. Mattoso toma-as como critério para classificar certos autores: "Aristarco era analogista; os Estóicos, com destaque para Crates de Malo, eram mais ou menos anomalistas (CÂMARA JR., 1986, p. 18)". Toma-as igualmente, ao historiar as ideias linguísticas que levaram ao advento do estruturalismo, como critério para organizar a longa história do estudo da linguagem:

\begin{abstract}
Uma observação parcelada dos fatos, que são em seguida somados por um processo associativo, ou analógico lato sensu, vai do analogismo greco-latino aos neogramáticos, como vimos em Hermann Paul, até à gramática psicológica em geral, ou psicologismo gramatical, baseado na psicologia individual clássica e no mecanismo das associações. / Contrapõe-se-lhe a construção de uma gramática em têrmos lógicos, de que são deduzidos os componentes. É ela que está no cerne do conceito tradicional de gramática. Repete-se numa longa história, que vem de Aristóteles e Platão, consolida-se em Dionísio da Trácia, prolonga-se na Idade Média, reformula-se com a gramática de Port-Royal, e é afinal rechaçada pela lingüística oitocentista, que assenta francamente no empirismo. / Entre as duas hostes antagônicas, como uma terceira força (...), encontra-se o anomalismo, cujo princípio diretor é a afirmação do fenômeno lingüístico como visceralmente individual e particular. Transplanta-se do anomalismo grego para o pensamento de Schuchardt e Gilliéron, (...). Um seu aspecto típico é a diluição da lingüística noutra área de estudo, que é a etnografia com Schuchardt e Meringer, através da doutrina das "palavras e coisas", ou a estética com Croce e a corrente vossleriana, ou a história social e política com Menéndez Pidal (CÂMARA JR., 1968, p. 9).
\end{abstract}

O segundo exemplo emblemático do aspecto embotado com que os conhecimentos da Antiguidade Clássica aparecem no HR de Mattoso é sua abordagem do pensamento platônico. Discute apenas a questão thései / nómoi encontrada no 
Crátilo; repercute também a forte presença da etimologia, contrastando-a com a etimologia moderna:

\begin{abstract}
Nada tinha a ver com o que a moderna lingüística atribui hoje a esse termo, mas uma pesquisa do "verdadeiro" significado de um vocábulo baseada na análise de suas partes constituintes. Em vez de uma explicação sobre a origem de um vocábulo colocada numa perspectiva histórica, a filosofia grega visava uma compreensão da ideia original que dera lugar a esse vocábulo e ainda mantém sua verdadeira significação, uma vez que a língua não era vista como um acontecimento histórico em mutação (CÂMARA JR., 1986, p.17)
\end{abstract}

A falta de uma discussão sobre o Sofista, importante diálogo platônico em que as questões sobre linguagem apresentadas no Crátilo são desenvolvidas, evidencia o papel que tais conhecimentos desempenham na produção de conhecimento e de saberes de Mattoso Câmara: são pontos referenciais, culturalmente importantes, na linha temporal do desenvolvimento dos estudos da linguagem, mas pouco produtivos no quadro epistemológico contemporâneo do autor, a saber, a linguística propriamente dita.

Em termos de estudo qualificado da linguagem, o que parece interessar sobremaneira a Mattoso é o surgimento da gramática na Antiguidade Clássica, que, numa perspectiva mais ampla, inaugura a linha histórica dos estudos "científicos" das línguas, permitindo assim seu desenrolar até o surgimento da linguística propriamente dita no século XIX. É este o enquadramento em que situa os conhecimentos produzidos por Aristóteles e pelos Estóicos:

Os fundamentos da gramática grega foram lançados por Aristóteles e continuados pelos Estóicos. Aristóteles via a língua através da lógica e desenvolveu o estudo lógico da linguagem, que prevaleceu até o advento da lingüística propriamente dita. Fez a primeira distinção nítida a respeito das partes do discurso (...) e sobre a estrutura da oração (o nome como sujeito e o verbo como predicado). Os estóicos, por outro lado, introduziram o conceito dos casos nominais (...) (CÂMARA JR., 1986, p. 18).

No entanto, a "gramática grega chegou ao seu auge no período helenístico. Suas formulações foram resumidas no pequeno trabalho de Dionísio da Trácia do século II a.C., cuja influência sobre todas as gramáticas subsequentes é incalculável (id. ibid.)". O conhecimento embotado aqui é a conformação da gramática como manual e modelo de 
análise linguística; muito mais que uma doutrina - de aspecto filosófico (paralinguístico) e baseada na teoria do "certo e errado" (pré-linguístico) - a que chamamos de gramática tradicional (Borges, 2012), o pensamento linguístico grecolatino legou-nos um instrumento linguístico (Aurox, 1998) capaz de impulsionar movimentos civilizatórios em diversas partes do globo.

O pensamento linguístico de Mattoso Câmara não reflete o contexto epistêmico da Antiguidade Clássica; o lugar que este ocupa em seu horizonte de retrospecção é restrito, os seus conhecimentos surgem aí de modo embotado, portanto não influem na produção científica de Mattoso. Desta feita, compreendemos que as emergências da ideia de frase elencadas na primeira parte deste capítulo não tenham sido levadas em conta por Mattoso. As únicas referências que faz a elas corroboram o caráter crítico com que avalia tal contexto epistêmico no que se refere à questão da frase. A primeira referência é geral e parte dos efeitos (negativos) de sua influência: “(...) a análise que se pratica é em bases estritamente lógicas, o que decorre da maneira por que se iniciou e se constituiu na velha Grécia como uma exegese da frase para fins filosóficos (CÂMARA JR., 1975 [1960], p. 63)”, o que retardou uma análise efetivamente linguística da frase; a outra, indexada por referência à Dionísio da Trácia, corrige o que considera um erro de tradução da famosa definição de frase do filólogo grego:

\footnotetext{
uma oração coordenada não forma sentido "completo", como se costuma dizer erroneamente por força de uma tradução falsa da definição de Dionísio da Trácia - "autotele", que no velho gramático alexandrino significa "autonomamente", isto é, com sua individualidade; assim, em "auriverde", "verde" tem a sua individualidade mas não dá o sentido completo para a verdadeira cor do pano, pois só se refere a uma parte dele (ibid., p. 66).
}

Esta mesma correção aparecera no Princípios de linguística geral (1974), indexada a correção ao nome de Alan Gardiner:

Também não é satisfatória e compreensiva a segunda parte da definição; a saber: sentido completo. Essa expressão foi sugerida pelo grego autoteles usado por Dionísio da Trácia (Gardiner, 1932, 99); mas o velho gramático como lùcidamente interpreta Gardiner - queria dizer com isso que a frase é uma palavra, ou conjunto de palavras, que para a comunicação lingüística, feita em dado momento, não depende de outras palavras anteriores ou 
seguintes. Não se trata assim de um sentido completo, mas de um funcionamento autônomo no intercâmbio social (CÂMARA JR., 1974, p. 164).

Não é, portanto, a partir do contexto da Antiguidade Clássica que o tratamento da questão da frase por Mattoso será configurado; no entanto, é aí que encontramos as raízes do contexto epistêmico gramatical que se inaugura com a Tekné de Dionísio, do qual Mattoso se serve como referência para avaliar os estudos da linguagem como cientificamente relevantes, este CE expandir-se-á amplamente até o advento do contexto epistêmico da linguística propriamente dita no século XIX. Em ambos os dois contextos a ideia de frase emerge, trazendo consigo conhecimentos já consolidados e o influxo para a elaboração de renovados conhecimentos linguísticos. 


\title{
Capítulo 2
}

\section{O TERMO FRASE: de sua entrada em França a sua ida ao Brasil}

A linguagem pode ser entendida de modo restrito - e banal - como "língua natural" ou, por outro lado, como "sistema de signos" (DUCROT; TODOROV, 2010, p. 9); também como "atividade criadora" (COSERIU, 2012, p.49). A constituição da linguagem como objeto de saber engendrou, ao longo do tempo, diferentes disciplinas que à medida de seus desenvolvimentos passaram a constituir estatutos de cientificidade próprios e a contar com epistemologias normativas ${ }^{34}$ específicas. Assim, da Antiguidade ao limiar dos tempos modernos, predominaram as disciplinas da Gramática, da Retórica e da Lógica. Ainda que a Antiguidade tenha tentado constituir uma ciência global da linguagem, como nos assegura Desbordes (1989, p. 152), reconhecia-se geralmente que a linguagem é matéria de muitas ciências ou disciplinas. Três delas, que mais tarde constituirão o Trivium medieval, acabaram por dividir, pouco a pouco, todo o domínio:

\begin{abstract}
la dialectique, qui traite des énónces dans leur rapport aux objets qu'ils sont censés représenter, et qui entend permettre de distinguer le vrai du faux; la rhétorique qui étudie les moyens de persuasion par la parole et envisage donc, dans les énocés, les effets qu'ils sont susceptibles de produire sur les auditeurs; la grammaire, qui est la science des énoncés "en eux-mêmes", si l'on peut dire, à la fois connaissance des contenus et analyse des éléments d'expression ${ }^{35}$ (DESBORDES, 1989, p. 152).
\end{abstract}

Neste capítulo, ocupar-nos-emos das representações do fenômeno linguístico ${ }^{36}$ FRASE elaboradas a partir dos contextos epistêmicos, CE, das tradições francesa e

\footnotetext{
${ }^{34}$ AUROUX (1980, p. 8): “(...) l'épistemologie normative (la traditionelle méthodologie qui définit a piori la correction des raisonnements, des protocoles expérimentaux, etc.)". Traduzimos: "epistemologia normativa (tradicional metodologia que define a priori a correção dos raciocínios, dos protocolos experimentais, etc.)"

35 Traduzimos: "a dialética, que trata dos enunciados em sua relação com os objetos que deveriam representar, pretende distinguir o verdadeiro do falso; a retórica, que estuda os meios de persuasão pela fala, considera, nos enunciados, os efeitos passíveis de serem produzidos por eles nos ouvintes; a gramática, que é a ciência dos enunciados 'em si mesmos', se assim podemos dizer, é de uma só vez conhecimento dos conteúdos e análise dos elementos de expressão”.
}

${ }^{36}$ Husserl assinala que o termo 'fenômeno' usualmente está carregado de equívocos e que convém prestar atenção à sua significação na medida em que se refere aos atos de representação intuitiva. Daí, diversos e, ao mesmo tempo, escalonados significados do vocábulo. Fenômeno significa, com efeito: 1) "a vivência 
brasileira dos estudos da linguagem, de modo a podermos situar na história das ideias linguísticas que ecoaram no Brasil, a Teoria da Frase finalmente elaborada por Mattoso Câmara em seu Princípios de Linguística Geral (1942). As causas e efeitos da atenção teórica dada a este fenômeno linguístico nas tradições francesa e brasileira constituem o objeto deste capítulo, dado que são estas as tradições com as quais a abordagem mattosiana dialoga; bem como, são elas que constituem seu contexto sociocultural.

Em 2.1 apresentamos um panorama histórico das concepções de gramática; em 2.2 apontamos as perspectivas historiográficas com que a questão da frase tem sido abordada; em 2.3 acompanhamos o percurso histórico da frase na tradição francesa; e em 2.4 chegamos à presença da ideia de frase em gramáticas brasileiras do século XIX; em 2.5 investigamos sua presença na gramaticografia de começos do século $\mathrm{XX}$, da qual Mattoso Câmara participa também com uma gramática escolar.

\subsection{Panorama histórico das concepções de Gramática}

Na esteira da tradição inaugurada pela Téchne Grammatikè, de Dionísio da Trácia, vemos a GRAMÁTICA emergir como teoria linguística, através da aplicação de suas categorias à descrição do latim. O latim pôde, assim, ser descrito de maneira sistemática com ajuda das categorias feitas para o grego. No fim do século II a.C., os romanos adotam a grammatikè grega, o que corresponde a uma naturalização da grammatica e do grammaticus. A gramática se insere, então, no contexto do ensino da leitura e da escrita já existente. Antes de tudo, trata-se de uma ciência de textos: como estabelece-los e interpretá-los (COLOMBAT et al., 2017, p.105-6).

Os estudiosos latinos abriram caminho para a emergência da gramática como manual de ensino de língua, tanto materna quanto estrangeira. Os gregos atentavam para sua língua como a única digna de estudo. A própria Téchne surge no contexto de

concreta da intuição" (o ter presente ou representado, intuitivamente, um certo objeto), e 2) "o objeto intuído (aparente) como o que aparece para nós hic et nunc". E, de um modo que induz a erro, também se chama de fenômeno 3) "os elementos reais do fenômeno no primeiro sentido, no sentido do ato concreto de aparição ou de intuição" (Investigações lógicas, VI. Apêndice apud MORA, 2005: 1017). Por fenômeno linguístico entendemos, na esteira dos significados 1 e 2, a vivência ou o objeto da apercepção dos elementos da linguagem. 
preocupações filológicas quanto à correção idiomática dos textos antigos. Assim, os latinos

\begin{abstract}
constantemente voltados para a comparação com [o] grego, utilizando os mesmos instrumentos de análise, [...] procuram estudar as características da linguagem em geral pelo exemplo do latim, "em que se pode dizer que os gramáticos gregos 'faziam' grego, os gramáticos latinos 'fazem' linguística (DESBORDES, 2000, apud COLOMBAT et al., 2017, p. 108).
\end{abstract}

Como resultado do interesse dos gramáticos latinos pela linguagem em geral, o latim, quando já entrado o medievo, passou a ser a língua por excelência da cultura e da ciência da época, bem como sua gramática tornou-se instrumento pedagógico, uma técnica de aprendizagem da língua, por sob o qual os vernáculos foram submetidos ao processo de gramatização, ou seja, sua descrição e instrumentalização por meio da elaboração de gramáticas e de dicionários (AUROUX, 2014, p. 65), processo que tomou impulso no século XVI.

De acordo com Colombat et al. (2017, p.109-10) podemos considerar que a tradição gramatical ocidental construiu-se em torno de alguns textos fundamentais; pode-se até afirmar que há mais ou menos quatro textos fundamentais, que constituíram uma base sólida para tudo o que veio depois. Trata-se da Téchne, de Dionísio da Trácia, do tratado sobre a sintaxe de Apolônio Díscolo, da Ars Grammatica, de Donato, e das Institutiones Grammaticae, de Prisciano.

Resta ainda mencionar outra emergência da gramática: a que a toma por método científico. Este aspecto da história da gramática foi assinalo por McLuhan (2012) em sua tese de doutoramento, na qual tenta indicar como a ciência e a gramática se vinculam naturalmente por meio da ideia da linguagem como expressão e analogia do Lógos. Para ele

Os estudiosos do período clássico têm se mostrado indiferentes ao extraordinário papel desempenhado pela gramática clássica na ciência e tecnologia do medievo, mostrando-se confusos, portanto, acerca da natureza do Renascimento. O eclipse do método gramatical causado pela matemática depois de Descartes reduziu a arte da gramática a questões de morfologia e sintaxe, fazendo com que essa mesma insignificância tivesse reflexos na gramática antiga (McLUHAN, 2012, p. 31). 
Com a Modernidade, cujas fronteiras com a Idade Média, do ponto de vista cultural, não são rigorosas (KNITTERMEYER, 1969, p. 189), como ademais, toda fronteira que pretenda demarcar zonas no espírito humano, vemos junto com um crescente sentimento vital do homem que se descobre novo, apartado de suas raízes religiosas, uma valorização dos vernáculos e sua consequente gramatização, sobretudo com o movimento humanista, e da razão, com os filósofos cartesianos, os iluministas e outros mais que tomam o homem como fonte e justificação últimas de si mesmo. $\mathrm{O}$ modernismo, que vem a ser o desdobramento de tendências já presentes nos princípios elaborados pela Modernidade ${ }^{37}$, substitui a ideia de Sujeito e a de Deus, da mesma forma que as meditações sobre a alma foram substituídas pela dissecação de cadáveres ou pelo estudo das sinapses do cérebro. A ideia de modernidade está, assim, estreitamente associada à de racionalização (TOURAINE, 1992, p. 24). A organização racional da vida passa a ser o modelo cognoscitivo da Modernidade; esta, no tocante à linguagem, reorientou as disciplinas da Gramática e da Filologia e forjou a da Linguística ${ }^{38}$.

A disciplina Gramática, no limiar da Modernidade e depois, apresentou, de modo alternado, as seguintes vertentes: racionalista, que entende a língua como intermediadora entre o pensamento e a realidade e adota como método de trabalho a especulação; e empirista, que mantém a relação pensamento-língua, mas liberta-se das disciplinas afluentes (da lógica, principalmente), adotando como método de trabalho a observação; privilegiando, portanto, o uso linguístico. As gramáticas empiristas do Renascimento - que começam a voltar-se para o uso e para a fundamentação de seus postulados em dados e fatos linguísticos, tal como em J. C. Sacaliger (1540), ou a introdução de princípios formais em lugar dos semânticos ou lógicos para distinguir as partes do discurso, como em Ramus (Dialectique, 1556, e Gramere, 1562) contrapõem-se às gramáticas racionalistas anteriores, dos modistas, que se ocuparam sobremaneira com a significação, a relação semântica sobre as designações e os objetos designados; entretanto, as gramáticas racionalistas não foram abandonadas, tendo seu programa retomado pelos jansenistas de Port-Royal (Séc. XVII) (SILVA, 2016).

\footnotetext{
${ }^{37}$ TOURAINE (1992: 24): "A ideologia ocidental da modernidade, a que podemos chamar modernismo (...)".

${ }^{38}$ Para as relações, por vezes conflituosas, entre Filologia e Linguística ver: ALTMAN (2004) e KOERNER (2014). Já para as relações entre Gramática e Linguística ver: BORGES NETO (2012) e SILVA (2016).
} 
$\mathrm{Na}$ esteira das constatações feitas por McLuhan (2012), podemos aventar a hipótese de que o modelo matemático que, a partir de Descarte, substituiu o gramatical, que fora o modelo cognoscitivo da Idade Média, levou à concepção positivista a partir da qual as ciências da linguagem passaram a se organizar na modernidade: os ideais humanistas que levaram ao florescimento da filologia clássica enrijeceram-se no método científico da crítica textual; a gramática, como teoria linguística, abandona os elementos expressivos e refina de tal modo seus dados que se perde num acumulo de minúcias formais ao ponto de engendrar um novo método, o linguístico:

Foi o conceito do parentesco das línguas que racionalizou os estudos lingüísticos; o ponto de partida foi a revelação do sânscrito aos sábios ocidentais; o conhecimento dessa língua - além de possibilitar fàcilmente, pelo menos em certos casos, a análise da palavra em seus elementos constitutivos - dava acesso à obra dos gramáticos hindus, tesouro de observações preciosas, particularmente instrutivas no tocante à classificação dos fonemas e à teoria da raiz e da formação das palavras (LEROY, 1971, p. 29).

O modelo formal da gramática sânscrita, bem como a concepção teórica do parentesco das línguas com base nas formas linguísticas, que tomou força com o conhecimento do Sânscrito, são os elementos que levam ao progressivo afastamento do ideário linguístico da Antiguidade Clássica e da elaboração do novo ideário científicoracional da Modernidade. Este afastamento reflete-se nas relações institucionais das disciplinas representativas de tais ideários. A Filologia Clássica demonstrou, à época, forte hostilidade para com a nova disciplina:

Os filólogos clássicos viam com maus olhos êsses intrusos que, com o auxílio de línguas que lhes eram desconhecidas e em nome de métodos que não podiam dominar, se pronunciavam sôbre questões de gramática grega e latina (...); os filólogos, apaixonados da boa linguagem e da boa literatura, enfureciam-se com a idéia de que o estudo das formas modernas do grego e do latim, ou de dialetos longínquos como o sânscrito ou o persa, ou, pior ainda, de falares incultos da Lituânia ou da Escandinávia, poderia fazer progredir seu conhecimento de Platão e de Cícero (...) (LEROY, 1971, p. 32).

Koerner (2014, p. 69) ao analisar os antecedentes históricos das relações entre Filologia e Linguística destaca que é a partir da influência de Schleicher (1821-1868) que se estabelece uma nítida distinção e divisão de trabalho entre elas: 
Para Schleicher, a 'Philologie' é uma 'disciplina histórica' que considera a linguagem como um meio para investigar o pensamento e a vida cultural de um povo. Por contraste, a 'Linguistik' (...) é um campo que se ocupa da 'história natural do homem'. De facto, a linguística (no modo schleicheriano de compreender a disciplina) é uma ciência natural por duas razões: porque o seu objeto de investigação é acessível à observação direta e porque a linguagem está fora do domínio da livre vontade do indivíduo (KOERNER, 2014, p. 69).

No contexto acadêmico luso-brasileiro, que nos interessa acompanhar mais de perto, tal distinção não se estabelece de maneira consensual. Altman (2004, p. 173) avalia os posicionamentos contrários de Adolfo Coelho (1847-1919) e de Leite de Vasconcelos (1858-1941) quanto a qual disciplina caberia o estudo científico (gramatical) da língua: à Glotologia, para o primeiro, ou à Filologia, de acordo com o segundo. A organização institucional e programática do pensamento linguístico brasileiro refletirá este conflito conceitual de modo que nos "círculos brasileiros do final do século XIX e primeira metade do século XX, circulavam, sob o amplo guarda-chuva do termo "filologia"” (ALTMAN, 2004, p. 176), figuras de interesse e orientação díspares que engendraram produtos nas áreas de edição de textos antigos, gramáticas históricas e normativas, dialetologia, etimologia, estilística, e crítica da literatura.

A gramática como instrumento linguístico teve um papel relevante na formação da inteligência brasileira, bem como na construção da identidade nacional: surge entre nós como instrumento etnográfico, a recolha linguística feita por Anchieta que resultou em sua gramática da língua brasílica; passa a ser instrumento civilizacional quando da aclimatação do português às terras brasileiras; chega a ser compreendida como ciência quando da emergência de uma efetiva vida intelectual eminentemente nacional, o que se deu na alvorada do século XIX. Estes movimentos foram alimentados por influxos vindos da Europa, sobretudo Portugal, França e Inglaterra; contemporaneamente os Estados Unidos da América passaram a também fornecer teorias linguísticas aos estudiosos brasileiros.

Durante largo tempo a gramática foi o produto científico por excelência dos esforços dos estudiosos da linguagem no Brasil; tanto que os programas de investigação em historiografia linguística vigentes no país atualmente tomam a gramática como principal objeto e campo de interesse. Cavaliere $(2002,2014)$ ao caracterizar os estudos 
linguísticos brasileiros apoia-se, sobretudo, nas alterações doutrinárias presentes em gramáticas de destaque, assim temos os períodos: embrionário, que parte da publicação da Gramática de Anchieta (1595) à publicação do Epítome de gramática portuguesa de Morais Silva (1806); racionalista, que vai da publicação do Epítome à publicação da Gramática portuguesa de Júlio Ribeiro (1881); científico, que se inicia em Júlio Ribeiro e termina com a publicação dos Princípios de linguística geral de Mattoso Camara Jr. (1970 [1941]); linguístico, que começa com a publicação dos Princípios e chega aos nossos dias.

Em termos programáticos emergiram, segundo Altman (2004), no período que vai do final do séc. XIX e primeira metade do séc. XX, pelo menos, ou seja, num lastro de tempo que alcança os períodos racionalista, científico e linguístico, três práticas de análise e descrição gramatical: 1) estudos históricos, ou comparativos, isentos de opiniões e respaldadas por documentos e fatos; 2) explicitamente prescritiva, de retórica abertamente purista; e 3) a que se insurgia contra certo "gramaticalismo" obtuso.

É neste contexto de estudos linguísticos, o século XIX brasileiro, que se encontra a tese "a frase como fenômeno lógico-gramatical", que no confronto com a antítese "a frase como fenômeno linguístico-gramatical", própria dos começos do século XX europeu e norte-americano, levará ao resultado dialético da síntese mattosiana "a frase como unidade do discurso e como unidade de língua”.

\subsection{A frase e sua Historiografia}

Marchello-Nizia (1979), Hauy (1983), Seguin (1993), Graffi (2001), Léon (2003) e muitos outros estudos têm evidenciado a complexidade do fenômeno linguístico frase no âmbito dos estudos da linguagem, sobretudo, quanto à disciplina gramatical; bem como apontando como principal fonte de dificuldades a conceituação do termo frase - noção muito cômoda quando evocada de longe, porém muito suspeita quando examinada de perto (MARCHELLO-NIZIA, 1979, p. 35).

De modo a desfazer os embaraços motivados pela confrontação da ideia de frase, estudiosos têm apontado a necessidade da abordagem histórica (SEGUIN, 1993), com especial atenção aos antecedentes do termo frase (LÉON, 2003). O recorte histórico 
varia de autor para autor; a Seguin (1993), por exemplo, interessa a invenção do conceito de frase no século XVIII francês; Léon (2003) vai mais longe ao traçar o percurso histórico do conceito de frase desde a Antiguidade Clássica, com a noção de proposição, até às noções de enunciado e enunciação na contemporaneidade - inclui notas sobre outras tradições ${ }^{39}$ de estudo, ainda que sua atenção esteja voltada para os desdobramentos que tal noção teve na tradição francesa nos vários períodos históricos; Graffi (2001) cuida das condições e formas da evolução das teorias sintáticas no período que se estende do fim da influência da gramática geral (primeiro terço do séc. XIX) ao declínio das concepções gerativistas; ainda que não seja um trabalho de historiografia, o estudo de Hauy (1983) apresenta um retrato do tratamento dado à questão da fraseloração pelos gramáticos brasileiros pós-NGB ${ }^{40}$ que ilustra muito bem a propalada confusão teórico-metodológica que se instalou nos manuais de gramática brasileiros quanto a esta temática; um tratamento historiográfico da questão no contexto brasileiro do séc. XIX encontra-se nos trabalhos acerca da gramaticografia brasileira de Polachini (2013, 2018).

A primeira e maior dificuldade ao se historiar as emergências da ideia de frase encontra-se no momento de dizer o que é a FRASE; temos, portanto, um problema de definição (no plano lógico) e de terminologia (no plano técnico); desta primeira dificuldade deriva-se outra, a de determinar o campo da linguagem onde essa noção adquire consistência, a questão língua/discurso; e ainda outra, a de determinar o papel que a frase tem desempenhado nas disciplinas linguísticas.

No âmbito das teorias linguísticas, parece-nos mais acertado acompanhar a abordagem aplicada à questão da frase por Graffi (2001) que a analisa historicamente a partir de sua dupla face: unidade de sentido e composto de elementos linguísticos menores.

A partir do conceito de oratio elaborado por Prisciano ${ }^{41}$ (480? d. C. - 530? d. C) Graffi (2001: 111) destaca os dois aspectos que a diferenciam de qualquer outra unidade

\footnotetext{
$39 \mathrm{Na}$ nota 21 menciona outras tradições gramaticais europeias, com destaque para a inglesa, acrescentando que nelas aparecem unidades intermediarias entre a palavra e a proposição (LÉON, 2003, p. 10).

${ }^{40}$ Nomenclatura Gramatical Brasileira, promulgada pela Portaria no 36, de 28/01/1959.

41 "oratio est ordinatio dictionum congrua, sententiam perfectam demonstrans (PRISCIANO, Institutiones grammaticae II, 4.15, apud Graffi?) que Graffi (2001: 113) traduz como "a sentence is a
} 
sintática: por um lado sua estrutura gramatical; por outro, sua capacidade de ser a expressão de um "pensamento completo". O autor os chama, respectivamente, de analítico e holístico. Destaca também, no período que analisa, duas abordagens na análise da frase: a primeira é o modelo judicativo representado por Port-Royal que concebia a frase como juízo, tendo ambos os mesmos elementos (sujeito - cópula predicado); a outra é representada pela sintaxe psicológica que coincidiu no tempo com o prestígio da gramática histórico-comparativa; sua figura mais representativa foi o psicólogo Wilhelm Wundt (1832 - 1920). Esta última abordagem concebia a frase como parte de uma representação total; do ponto de vista analítico era ela uma conexão de representações, quanto ao holístico correspondia às funções comunicativas.

Seguin (1993, pp. 04-12) aponta alguns dos elementos que compõem a problemática da frase: a perspectiva lógica em sua análise, a constante oscilação entre sistema e discurso e o status de modelo estético deste fenômeno linguístico. Para o autor, é este último o ponto sobre o qual a evidência da frase é, provavelmente, melhor compartilhada. Ressalta que a ligação da gramática com a estilística é fundamental para a concepção da frase (DELOFFRE, 1969: 20 apud SEGUIN, 1993: 9).

Hauy (1983), por outro lado, elenca e discute as definições de frase, oração e período dadas pelos gramáticos brasileiros do século XX. A autora fundamenta sua argumentação "numa discussão das mais graves falhas de nossos manuais: as falsas definições, a má exemplificação e a diversidade de conceituação e conseqüente multiplicidade de análise (Grifo nosso. HAUY, 1983: 5)". A diversidade de conceituação é a causa dos maiores transtornos no estudo da oração nos manuais de gramática.

\footnotetext{
Apesar das conclusões a que se tem chegado no estudo da conceituação de oração, demonstrando umas a discordância entre a análise gramatical vigente e o enfoque logicista que predomina nos conceitos sintáticos, atestando outras a diversidade de caracterização da estrutura oracional, determinada pela indistinção terminológica entre frase, oração e período, continuam os gramáticos definindo oração como expressão de um juízo ou de um pensamento, ou ainda, como um conjunto de palavras com sentido completo. Alguns também identificam oração com frase ou membro de frase com estrutura dual $(\mathrm{S}-\mathrm{P})$, outros a confundem com período simples. / São definições que evidentemente se repetem sem nenhuma convicção, na rotina centenária do 'magister dixit' (Grifos nossos. HAUY, 1983: 9-10).
}

coherent word combination, expressing a complete thought". Em português temos: "Frase - é a combinação de palavras, que exprimem um pensamento (CRUZ, 1955, p. 25)". 
Como podemos depreender da citação acima, as definições de cunho logicista "expressão de um juízo ou de um pensamento" - são persistentes na gramaticografia brasileira, em detrimento das evidências estruturais que melhor dariam conta do caráter heteróclito (CÂMARA JR., 1974) da frase; bem como, esta persistência tem por efeito obscurecer as diferenças de estrutura que os termos frase, oração e período possam vir a sugerir.

Polachini (2013, 2018), apoiada num aparato historiográfico mais apurado, dedica-se a traçar, inicialmente, a história do tratamento da sintaxe em gramáticas do século XIX, para tanto uma das temáticas por ela extensamente analisada foi a das definições de SENTENÇA ${ }^{42}$ em tais gramáticas; posteriormente ampliou seu escopo de interesse ao propor uma história serial com base em redes conceituais destas gramáticas do século XIX:

\begin{abstract}
Nossa hipótese, baseada em Auroux (2009 [1992]) e Swiggers 92010), é de que alguns conceitos, que chamamos de conceito-chave, poderiam ser eixo de uma rede conceitual devido à sua influência técnica e, eventualmente teórica, em uma determinada tradição de descrição linguística. No caso da tradição gramatical oitocentista brasileira do português, supomos que 'verbo substantivo' seria um conceito-chave produtivo, visto que é frequentemente apresentado nas obras dessa tradição, que são, por sua vez, amiúde influenciadas pela tradição da grammaire générale fracesa, ao menos até 1880 (...). Sabemos, por meio de trabalhos que se debruçaram sobre a tradição da grammaire générale, que o 'verbo substantivo' estaria relacionado com outros conceitos (...) (POLACHINI, 2018, pp. 12-13).
\end{abstract}

A autora considera rede conceitual as relações travadas entre o conceito-chave e outros conceitos da tradição em apreço. É no contexto destes outros conceitos que situa a "oração (seus elementos e sua organização)" (id. ibid.).

\title{
2.3 O termo frase e sua definição em França
}

O modelo de análise lógica que tanta influência exercerá sobre a análise da frase, ou análise sintática, praticada no Brasil durante largo tempo adveio da Grammaire de Port-Royal (1660). No entanto, na obra de Arnauld e Lancelot a proposição é pouco

\footnotetext{
${ }^{42}$ Termo privilegiado na exposição da autora.
} 
abordada. De acordo com Léon (2003) é na segunda parte da Logique ou l'art de penser de Arnauld e Nicole $(1662,1683)$ que se encontra a elaboração da proposição como noção gramatical, o que levará a autonomização da sintaxe a partir da análise lógica e gramatical da proposição, da elaboração da noção de subordinação e a necessidade de dar conta da relação entre proposições simples e complexas. Permanece, porém, a identificação da proposição com o julgamento/juízo. Será Du Marsais, dissociando-se de Port-Royal, quem estabelecerá uma distinção estrita entre julgamento, o juízo como ato de pensar algo sobre uma coisa, e proposição, conjunto de palavras com um sentido definido que exprime um juízo.

Com base em Léon (2003) podemos identificar quatro momentos importantes no percurso histórico da ideia de frase: o primeiro deles na Antiguidade, com a Teoria da Predicação, forjada por Platão e modificada por Aristóteles; o segundo com Port-Royal e a progressiva autonomia da sintaxe, bem como, a consequente distinção entre o aspecto lógico e o aspecto gramatical da proposição; em seguida, a entrada do termo frase na gramática escolar a partir da fixação de sua noção por Domergue (1798); por fim, a emergência das teorias enunciativas no século XX.

Observemos na linha do tempo ${ }^{43}$ a seguir, o percurso do termo frase na tradição francesa de estudos da linguagem:

\footnotetext{
${ }^{43}$ Traçada a partir de Léon (2003).
} 


\section{Dictionnaire de l'Académie}

1694 (1 ed.)

Def.

Período: "parcela de um discurso, consiste m um certo arranjo de palavras, composto de vários membros, contendo um sentido completo".

\section{8 (5 ed.)}

1596

Entrada na língua francesa a partir da Retórica de Aristóteles.

Def.

frase complexa de certa extensão formando uma unidade rítmica. por vários membros, cuja reunião forma um sentido completo".

$$
1835 \text { (6 ed.) }
$$

"em termos de gramática".
1755

1782

Encyclopédie méthodique

Analisa de maneira homogênea

os elementos que constituem a

proposição e aqueles que

constituem o período. Desta

maneira, considera-os como uma

porção do discurso participando

uma só vez da retórica e da

"diz-se também de uma frase composta $\begin{gathered}\text { gramática, antecipando a } \\ \text { concepção da frase como unidade }\end{gathered}$

$$
\text { do discurso. }
$$

\section{Def.}

“em termos gramaticais e retóricos, é uma pequena extensão do discurso que contém um sentido completo, do qual distinguimos o final por um ponto e a partes ou divisões por vírgula, ou por ponto e vírgula, ou por dois pontos".

$$
\text { Obs. }
$$

O período, termo da retórica, participa do sentido moderno da frase através da ideia de delimitação física por meio da pontuação e de sentido completo que aqui parece fazer mais se referir à unidade semântica que à completude sujeito/predicado da proposição.

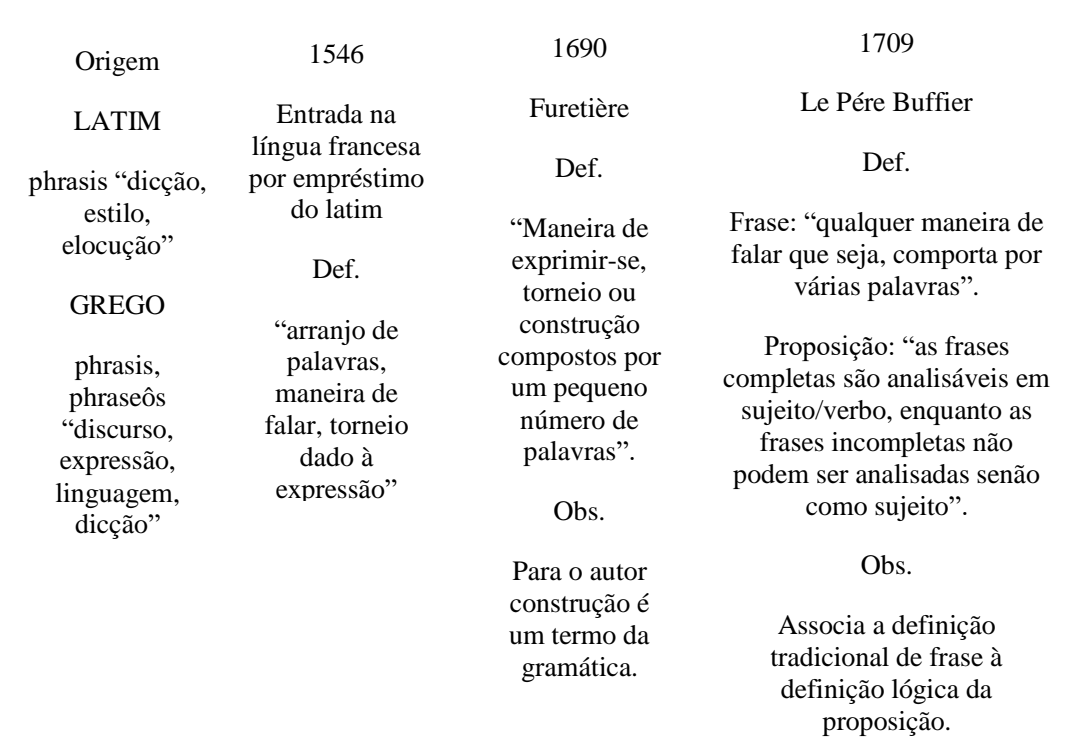

1722

Du Marsais

Def.

"Frase é uma palavra genérica que é dita de qualquer conjunto de palavras relacionadas entre si, quer façam sentido finito, quer esse ignificado seja incompleto. Esta palavra frase mais particularmente dita de uma maneira de falar, uma expressão, como as palavras são construídas e montadas de uma maneira particular. Quando queremos dar uma razão para uma frase, devemos sempre reduzi-la à proposição e completar seu significado, para desvendar exatamente as relações que as palavras têm entre elas de acordo com o uso da linguagem em questão."

Obs.

Para o autor, a frase não é uma unidade gramatical. Para ser analisada gramaticalmente, a frase precisa ser reduzida a uma proposição.
1765

Beauzée

Def.

Séc. XVIII

Gramática

Def.

Frase: "maneira de falar, caracterizando o gênio de cada língua"

"todo conjunto de palavras reunidas de modo a exprimir uma ideia qualquer"

Obs.

Associa a definição tradicional de frase à uma definição de frase enquanto construção.

FRASE
Buffier: interesse pela pontuação; nova relação entre oral e escrito $=$ a frase como uma unidade gráfica.

Frase e exemplo são termos usados um pelo outro nos textos gramaticais.

O ensino do Latim permite à Frase vir a ser, senão uma unidade gramatical, ao menos um elemento de estudo fundado empiricamente sobre textos a traduzir e a analisar.

Neste uso, associado à ideia do gênio da língua (frase grega, latina, italiana etc.), a frase é sempre um arranjo qualquer de palavras, sem que sua estrutura seja considerada. 


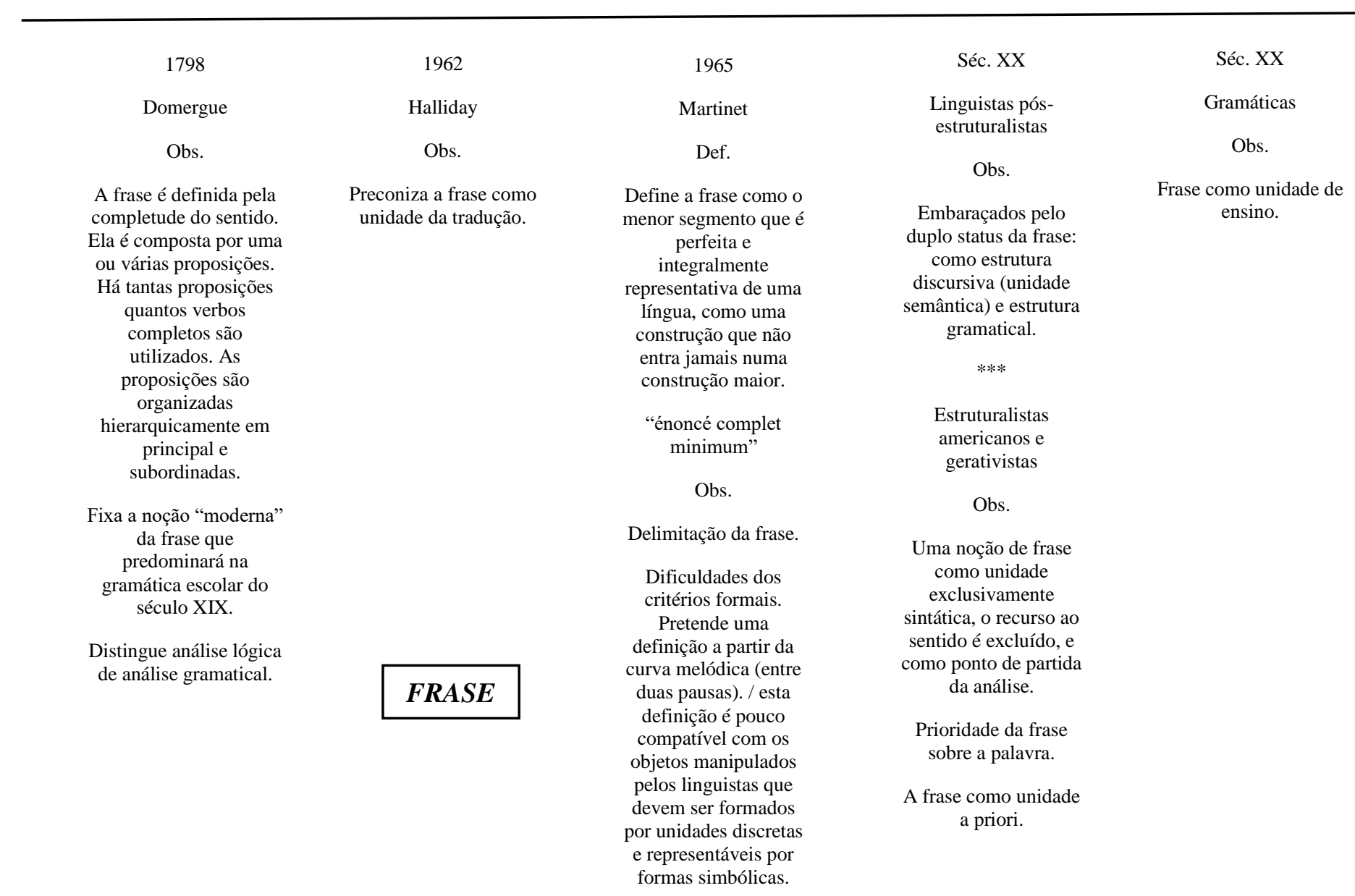


Como pudemos ver, o termo frase foi colhido pela tradição francesa na tradição latina, que por sua vez foi buscá-lo na tradição grega. Nesta última, de acordo com Bailly (1935, p. 2095), seu significado é: 1. ação de se exprimir pela fala, elocução, linguagem, de onde caráter expressivo de uma palavra; 2. discurso. Refere o dicionarista os seguintes autores que utilizaram o termo com a primeira acepção: Aristóteles (384322 a. C.), Dionísio de Halicarnasso (30 a. C.), Plutarco (30 d. C.) e Longin (213-273 d. C.). Quanto à segunda acepção registra o nome de Elien, sofista do séc. III d. C.

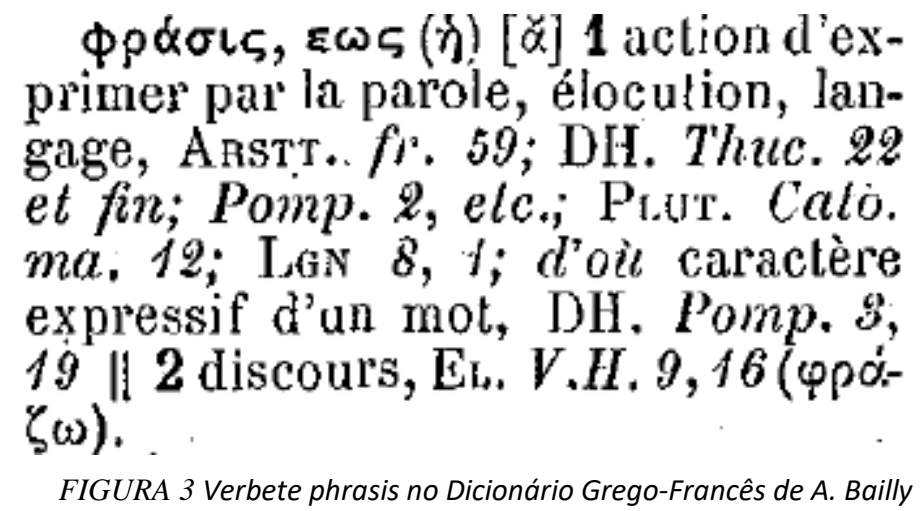

Já o termo período, que rivalizará mais diretamente com frase como termo da gramática, tem sua origem na Retórica de Aristóteles. Por já ter uma configuração técnica mais ou menos elaborada, ainda que em outra área do saber linguístico, cremos ter sido mais fácil ao termo período ser aclimatado ao ambiente gramatical. Quanto ao termo frase, lento e demorado foi seu processo de assimilação neste mesmo ambiente, devido a sua forte conotação de senso-comum. Conotação que prevalece em outras tradições que não assimilaram o termo a suas gramaticografias, caso da tradição brasileira. O termo frase adaptou-se, por outro lado, ao ambiente da Linguística, sobretudo aquele interessado na prática discursiva.

Furetière (1690) ao considerar a construção ${ }^{44}$ como um termo de gramática prepara as condições para a inserção também da frase neste universo; assim como Le Pére Buffier (1709) dá um passo importante ao associar a definição tradicional de frase à definição lógica da proposição; Du Marsais (1722), freará este processo ao negar a entrada da frase no ambiente gramatical, subordinando-a à proposição - para ele a frase

\footnotetext{
44 "en grammaire, se dit de l'arrangement et du régime des mots suivant les règles de la syntaxe (FURETIÈRE, 1690, apud LÉON, 2003, p. 9)". Traduzimos: "em gramática, refere-se ao arranjo e ao esquema de palavras de acordo com as regras da sintaxe".
} 
não era uma unidade gramatical; para ser analisada gramaticalmente precisava ser reduzida a uma proposição; Beauzée (1765), no entanto, será aquele que associará a definição tradicional de frase à definição de frase enquanto construção; por fím, Domergue (1978) fixa a noção moderna da frase que predominará na gramática escolar, outra contribuição sua é a distinção entre análise lógica e análise gramatical; modernamente, a frase encontra espaço na Linguística, ainda que sob diversa conceituação: enunciado completo mínimo (Martinet); estrutura discursiva, unidade semântica, e estrutura gramatical (linguistas pós-estruturalistas); unidade a priori (estruturalistas americanos e gerativistas); unidade de ensino (gramáticas escolares).

\subsection{A frase em gramáticas brasileiras do Século XIX ${ }^{45}$}

O percurso da ideia de frase na tradição brasileira de estudos da linguagem tem seu ponto de partida na tradição francesa, mais especificamente, na tradição epistemológica da gramática geral (POLACHINI, 2013) e em seu conceito de proposição como expressão de um juízo (aspecto holístico) e de estrutura tripartite (aspecto analítico); ao longo do percurso da frase na gramaticografia brasileira do século XIX podemos identificar a presença também da tradição inglesa quanto à conceituação da frase, desta advém a concepção de frase como "unidade intermediaria entre a palavra e a proposição (LÉON, 2003, p. 10)”. A par destas duas concepções encontramos na gramaticografia brasileira o problema das equivalências terminológicas no âmbito da teoria da frase: para muitos gramáticos FRASE, ORAÇÃo e PERÍODO são termos equivalentes; aceitar sem mais tal equivalência, a nosso ver, é um erro na medida em que cada termo pode corresponder a um dado aspecto da frase como fenômeno linguístico total e revelar assim áreas de saber específicos no campo mais amplo dos conhecimentos da linguagem. Nosso trabalho aqui é de cunho historiográfico; a trama que temos tentado reconstruir é a da conceituação daquilo que Mattoso (1974) chamou com Gardiner de "unidade do discurso". Ressaltamos, portanto, que neste tópico

\footnotetext{
45 A maior parte das gramáticas referidas neste tópico foram consultadas no site http://ctlf.enslyon.fr/default.htm. O CTLF (corpus de textes linguistiques fondamentaux) é um site que dá acesso: a uma base de notices que descrevem as principais obras gramaticais e linguísticas das grandes tradições linguísticas, da Antiguidade ao século XX; a uma bibliografia complementar de mais de 3000 referências; a uma base textual (versão em imagens) de aproximadamente uma centena de obras; a uma base textual (versão texto); a uma base de artigos e documentos produzidos pela equipe de pesquisadores envolvidos.
} 
traçamos, de modo parcial, o percurso da ideia de frase na gramaticografia brasileira, levando em conta apenas os aspectos sumariados neste parágrafo.

Por volta da segunda metade do século XIX as gramáticas mais usadas no Brasil eram: a Gramática Filosófica da Língua Portuguesa (1822), de Jerônimo Soares Barbosa e a de Antonio de Moraes Silva, Epítome da Gramática Portuguesa (1806) (FÁVERO; MOLINA, 2013, p. 194). É a partir da influência daquela que a equivalência terminológica emergiu como a confusão conceitual que caracteriza o tratamento da teoria da frase entre nós.

A Epítome constitui, nas palavras de Cavaliere (2014), a primeira tentativa de descrição sistêmica do português edificada por um brasileiro, fato que confere a esse trabalho especial valor historiográfico. É ela o marco inaugural do período racionalista e, a rigor, nos parâmetros que o autor adota, dos próprios estudos linguísticos brasileiros, já que o período anterior não oferece senão obras esparsas e pouco relevantes no que diz respeito à formação do pensamento linguístico brasileiro. No que toca à teoria da frase, a partir da perspectiva da História das Ideias Linguística, é nela que encontramos a presença do modelo inglês de conceituação da frase, além do hibridismo característico de tradições de recepção como é a brasileira, pois mistura concepções inglesas às concepções francesas. No que toca à tradição inglesa encontramos desde a escolha do termo chave "Sentença" até à concepção de frase como unidade intermediaria entre a palavra e a proposição.

Além do período que permaneceu na Inglaterra, de 1779 a 1788, tomamos como indício do contato de Moraes Silva com este modelo sua referência à gramática do Reverendo Robert Lowth, Short Introduction do the English Grammar (1799). Vejamos o que Lowth diz sobre aquilo de que trata a gramática:

Grammar treats of sentences; and of the several parts of which they are compounded. / Sentences consist of words; words, of one or more syllables; syllables, of one or more letters. / So that letters, syllables, words, and sentences, make up the whole subjest of $\operatorname{grammar}^{46}$ (LOWTH, 1799, pp. 1-2).

\footnotetext{
46 Traduzimos: "A gramática trata das sentenças; bem como das muitas partes de que elas se compõem. Sentenças são feitas de palavras; palavras, de uma ou mais sílabas; sílabas, de uma ou mais letras. Então estas letras, sílabas, palavras e sentenças compõem todo o assunto da gramática".
} 
Agora comparemos com o que Moraes Silva nos diz acerca da mesma questão:

Trata pois a Gramática das Sentenças (isto é, ensina a fazer proposições, ou sentidos perfeitos) e das diversas partes, de que elas se compõem. // As sentenças constam de Palavras; as Palavras de Sílabas; as Sílabas de Sons elementares, e suas modificações; este representam-se aos olhos com letras (MORAES SILVA, 1806, pp. 9-10).

A ressalva acrescentada por Moraes Silva ao identificar sentença com proposição e proposição com sentido perfeito o coloca na esteira da tradição de maior prestígio, a francesa. A terminologia da teoria da frase presente na Epítome inclui:

Oração: Da boa composição das partes da oração entre si resulta a sentença, ou sentido perfeito, com que nos fazemos entender, falando com palavras.

Proposição: Todas as sentenças se reduzem declarar o que julgamos das coisas. Donde se vê que a sentença é proposição ou exposição com palavras do que passa na nossa alma, quando julgamos ou queremos.

Sintaxe: Todo o artifício, pois, de compor sentenças consiste em mostrar as conexões, ou as correlações entre os nomes de coisas e seus atributos significados pelos adjetivos; entre os nomes das coisas e os adjetivos articulares que os modificam determinando a extensão em que se tomam; e entre os nomes sujeitos e os atributos anexos aos verbos com a afirmação ou querer. As regras que ensinam a mostrar as conexões entre os nomes e os adjetivos e os verbos se dizem sintaxe de concordância [também sintaxe de regência e sintaxe/composição figurada].

Frase: Os Gramáticos Gregos confundem os advérbios com as interjeições, mas estas equivalem a uma sentença perfeita com verbo, os advérbios a uma frase modificativa do atributo verbal, de adjetivos e nomes atributos. Elipse é falta de palavra que facilmente se entende e supre: v.g. a frase elíptica "a Deus" a que faltam as palavras "te deixo" 
Quanto à estrutura, Moraes Silva considera que a sentença é composta por:

\begin{tabular}{|c|c|c|c|}
\hline SUJEITO & ATRIBUTO & VERBO & \\
\hline $\begin{array}{l}\text { De quem se afirma, o } \\
\text { qual deve ser um nome } \\
\text { só, ou modificado por } \\
\text { articuladores e } \\
\text { atributos. }\end{array}$ & $\begin{array}{l}\text { Que se declara por } \\
\text { adjetivos atributivos, } \\
\text { outras vezes por } \\
\text { nomes com } \\
\text { preposições. }\end{array}$ & $\begin{array}{l}\text { Afirma e ajunta os } \\
\text { atributos aos sujeitos ou } \\
\text { exprime a vontade e o } \\
\text { mando. Às vezes } \\
\text { significa ação. } \\
\text { CIRCUNSTÂNCIAS: } \\
\text { de lugar, tempo, modo, } \\
\text { instrumento, fim etc. }\end{array}$ & $\begin{array}{l}\text { Sentenças Incidentes } \\
\text { Modificam uma palavra } \\
\text { da sentença principal. } \\
\text { EXPLICATIVAS } \\
\text { DETERMINATIVAS }\end{array}$ \\
\hline
\end{tabular}

Moraes Silva (1806) não apresenta uma definição clara do termo frase; no entanto, a partir de passagens semelhantes à transcrita acima, tais como a que segue -

Todas éstas frases com ternura, com constancia modificão o verbo ame, determinando o modo de amar; naquelle lugar, ou ali, determinão uma circunstancia do verbo estar; de boa mente, de má mente, modificão a acção do verbo fez, \&c. Estas frases pois se chamão frases adverbiáes (...) (MORAES SILVA, 1806, 65).

- podemos inferir que o gramático Moraes Silva concebia a frase à moda inglesa, como "two or more words righly put together, in order to make a part of a sentence; and sometimes making a whole sentence (LOWTH, 1799, p. 68)".

O termo oração aparece como elemento da expressão "partes da oração"; é, portanto, a emergência da antiga tradição de categorização gramatical que os gregos chamavam de mere logou e os latinos partes orationis.

De cada uma d'estas partes da Oração, ou da Sentença direi aqui a natureza, e usos, e assim os accidentes, de que se acompanhão. No Livro seguinte da composição d'ellas em Sentenças, e Proposições (MORAES SILVA, 1806, p. 18).

As palavras ou partes da oração aí consideradas são: Nome ou Substantivo; adjetivos articulares; adjetivos atributivos; verbos; advérbios; preposições; e conjunções. 
Para Cavaliere (2014, p. 64) Moraes Silva envereda pela opção da sintaxe analítica, com base nas funções determinadas pela regência e pela posição da palavra na frase. No entanto, ponderamos que na concepção deste gramático é por meio das sentenças que "nos fazemos entender, falamos por palavras", ou seja, nos comunicamos; comunicamos aquilo que "se passa em nossa alma quando julgamos ou queremos"; compor sentenças nada mais é que explicitar as conexões ou correlações entre as partes da oração. Para além de uma analítica, a nosso ver, há na Epítome o interesse pelo caráter produtivo da linguagem.

A Gramática Filosófica foi a obra que tornou célebre Jerônimo Soares Barbosa; publicada postumamente, em 1822, ela se insere na tradição «universal e filosófica» de Port-Royal; ao seguir os princípios racionalistas, entremostra o conhecimento aprofundado, por parte do autor, das gramáticas racionalistas anteriores, mas também a leitura dos franceses Beauzée e Du Marsais (LUPETTI, 2015). Barbosa compreende a língua como "instrumento analítico" do pensamento; defende, também, o princípio segundo o qual, se os homens pensam conforme as mesmas leis, todas as línguas devem ser governadas pelos mesmos princípios gerais ou universais. Define, assim, ainda de acordo com Lupetti (ibid.) uma gramática geral como um sistema metódico de regras que resultam das observações sobre os usos e fatos da língua. Na esteira da Grammaire Générale et Raisonée, Barbosa elabora uma gramática que trata a língua tanto como objeto de estudo quanto como objeto de ensino, as duas finalidades imbricadas (SILVA, 2016). Esta dualidade será também uma constante na gramaticografia brasileira que, sobretudo no começo do século XX, buscará coadunar a atividade de pesquisa com a atividade de ensino (CAVALIERE, 2014).

Barbosa (1822, p. 363) define: “Oração, ou Proposição, ou Frase (pois tudo quer dizer a mesma coisa) he qualquer juízo do entendimento expressado com palavras". Para Silva (2016, p. 43) ao começar assim sua gramática, Barbosa "se afasta dos racionalistas franceses que distinguem frase (=constituição formal) de proposição (=conteúdo semântico)". Esta despreocupação com a precisão conceitual de cada termo aí referido não impede que adote como termo chave, no entanto, ao que nos parece, o termo "Oração": 
Toda Oração, que faz sentido perfeito, e gramaticalmente independente de outra, quer seja pequena, quer seja grande, quer conste de uma só proposição, quer de muitas, tem um ponto simples no fim, se é simplesmente enunciativa.

Aqui, como na Epítome, vemos o traço "sentido perfeito" como caracterizador do aspecto holístico. Agrega, no entanto, à constituição da "oração", como unidade, os aspectos: da gramaticalidade, uma "oração" pode depender gramaticalmente de outra; da possibilidade de ser composta por múltiplas proposições; da forma gráfica que adota, tem um ponto simples no fim; e do caráter enunciativo. Este último aspecto evidenciase também na concepção de discurso apresentada por Barbosa (1822, p. 363): "Ora não sendo qualquer discurso outra coisa senão um juízo ou uma série deles, todo ele não é também senão ou uma oração ou uma continuação de orações". A concepção de "oração" de Barbosa, portanto, guarda o interesse pela dimensão enunciativa da frase, ou melhor dizendo, pela ideia de que a frase expressa o juízo elaborado pelo sujeito, independente da situação de comunicação.

A equivalência terminológica de que temos falado aparece nos seguintes trechos:

\begin{abstract}
Pelo que temos dito se vê, que qualquer frase, ou oração, para ser cheia e inteira, deve ter um sujeito, um verbo, e um atributo ou separado, ou incluído no mesmo verbo; e qualquer dos termos da proposição, ou oração tendo significação ou ativa, ou relativa, deve ter um complemento, que lha complete e termine; e todo o complemento um antecedente, ao qual se refira. // Pela segunda razão, inverte-se muitas vezes a ordem da frase, ou do período para pôr desde logo à vista uma ideia interessante, sobre que queremos se fixe a atenção do ouvinte; a qual ideia em meio da oração ficaria encoberta; porém posta ou no princípio, ou no fim dela, faz mais impressão (Destaque nosso).
\end{abstract}

Estes trechos deixam entrever por meio dos pares postos em questão certas nuances conceituais: o primeiro par, frase / oração, aponta para o contexto da enunciação, pois significam um construto que precisa ser "cheio e inteiro"; o segundo par, proposição / oração, sugere o conteúdo a ser veiculado, a saber, o juízo elaborado; por fim, o terceiro par, frase / período, indica o contexto formal no qual pode-se alterar a ordem de aparição de seus elementos conforme o critério retórico: fixar a atenção do leitor. 
Estruturalmente toda oração tem, para Barbosa, necessariamente, "três termos, um que exprime a pessoa ou coisa, da qual se diz e enuncia alguma coisa; outro que exprime a coisa, que se enuncia; e o terceiro que exprime a identidade e coexistência de uma coisa com outra”. Respectivamente, o Sujeito, o Atributo e o Verbo, os quais podem ser expressos com três palavras (Eu sou amante); ou com duas equivalentes às três (Sou amante), ou com uma só, que concentra em si as três (Amo).

A seguir elencamos outras concepções da frase presentes em gramáticas do século $\mathrm{XIX}^{47}$. O critério que norteou a seleção destas gramáticas foi $\mathrm{o}$ da representatividade no panorama da gramaticografia brasileira, sobretudo na leitura de Fávero \& Molina (2013):

FREI CANECA (1876)

As línguas são compostas de frases, ou de sentenças, ou de orações ${ }^{48}$; as frases de palavras (...). // A sintaxe é a quarta parte da gramática que ensina a compor perfeitamente a oração. // Oração é um ajuntamento de palavras pelo qual exprimimos os nossos pensamentos (...). // Oração é uma reunião de palavras pela qual exprimimos nossos pensamentos. Considera-se de três modos: quanto à construção, quanto à significação, quanto ao número. Quanto à construção a oração divide-se em direta e indireta. // As partes essenciais da oração ou frase são três: sujeito ou agente, verbo ou nexo, paciente ou atributo. // Sujeito é a palavra, que exercita a ação do verbo. // Verbo é a palavra, que mostra a ação do sujeito. // Atributo é a palavra, que recebe a ação do sujeito, v. g: Antônio educou a Pedro com todo o zelo.

\footnotetext{
${ }^{47}$ Atualizamos a ortografia dos trechos selecionados.

${ }^{48}$ Destacamos os trechos que evidenciam a pretendida equivalência terminológica.
} 
REIS (1871)

O discurso consta de proposições: a proposição de palavras. // Proposição, que também se chama oração, frase, sentença, é o enunciado do juízo, ou ato do entendimento, pelo qual afirmamos uma coisa da outra. Toda reunião de palavras, a qual forma sentido, é uma proposição, em que se contém três termos, denominados, sujeito, verbo, atributo. // A ordem inversa domina ordinariamente na frase portuguesa, e com especialidade na dos escritores denominados clássicos; por isso cumpre saber bem distinguir uma de outra ordem, para conhecer os termos da proposição. // A proposição, que é, como fica dito, o enunciado do juízo e sem a qual não pode haver discurso, ou forma por si só, ou concorre com outras para formar uma frase, ou sentido completo e absoluto. Esta frase ou sentido que se liga a outros para formar o discurso, é o que se chama período gramatical, o qual é simples se consta de uma só proposição, composto se de mais de uma. Toda a reunião de palavras, a qual forma sentido, é uma proposição, em que se contem três termos, denominados, sujeito, verbo, atributo. Sujeito, é a pessoa ou coisa a que se atribui alguma qualidade: é a ideia principal, o objeto do juízo. Atributo, é a qualidade que se atribui ao sujeito: é a ideia acessória. Verbo, é o nexo entre os outros dois termos.

RIBEIRO, JÚLIO (1885)

Sentença é uma coordenação de palavras ou mesmo uma só palavra formando sentido perfeito (...). Sentença do Latim sententia (pensamento, juízo, expressão completa) é denominação preferível a período ${ }^{49}$. Com efeito, o termo período, do Grego periodos (caminho de volta, rodeio) não traduz bem a noção de pensamento, de juízo. Aristóteles e Cícero empregaram-no com a significação de "sentença retórica", figurada, ornada. Por "formar sentido perfeito" entende-se: dizer alguma coisa a respeito de outra de modo completo. // Toda sentença consta de dois elementos: 1) o que representa a

\footnotetext{
${ }^{49}$ Depois de Júlio Ribeiro (1885) apenas Maciel (1894), no corpus aqui considerado, apresenta defesa de um dos termos em jogo; no caso, Maciel prefere o termo proposição.
} 
coisa a cujo respeito se fala, chama-se sujeito; 2) o que representa o que se diz a respeito do sujeito, chama-se predicado. // $\mathrm{O}$ ato da mente pelo qual o predicado se liga à noção expressa pelo sujeito chama-se juízo. // O resultado de um juízo é um pensamento. // A expressão do pensamento é a sentença. // Quando uma sentença se compõe de duas ou mais asserções, cada uma dessas asserções chama-se membro (...). // Chamam-se clausulas os membros da sentença quando são tão conexos que um depende do outro e até o modifica. // Frase é uma combinação de palavras coordenadas entre si, mas sem formar sentido perfeito.

RIBEIRO, JOÃO (1887)

O fim da sintaxe é determinar a disposição a que devem obedecer os vocábulos para que exprimam um juízo ou proposição; e ainda determinar a disposição a que devem obedecer as proposições para que formem um sentido completo ou período. // (...) convém adiantar algumas noções sobre a proposição em geral. // Proposição é todo o agrupamento de palavras formando juízo, isto é, alguma afirmação. A proposição contém dois elementos capitais e indispensáveis: o sujeito e o predicado.

MACIEL (1894)

Fraseologia é o tratado das proposições e das suas diversas relações. // Proposição é um pensamento expresso por uma ou mais palavras. // Dois são os termos da proposição: sujeito e predicado. // As proposições também se dizem clausulas, frases, sentenças ou orações, mas todos esses termos se devem substituir pelo de proposição $^{50}$, por ser este mais geral e estar mais de acordo com as teorizações da lógica e simplificar mais a aprendizagem.

\footnotetext{
${ }^{50}$ Ver nota 49.
} 
Estes excertos ilustram o percurso da ideia de frase no alvorecer de nossa gramaticografia. Este percurso tem como linhas de desenvolvimento: 1) da expressão de um juízo chegamos à expressão do pensamento, o que pode indicar o abandono do escopo lógico em prol do escopo psicológico que a linguística adotaria, à semelhança do que ocorria a partir dos neogramáticos; 2) de uma estrutura trimembre a uma bimembre (sujeito + predicado), sendo este um ponto crítico da historiografia linguística na medida em que fica a questão da aclimatação de conceitos da lógica ao ambiente gramatical; os conceitos envolvidos na estrutura bimembre advém da lógica, mas com conotações gramaticais nítidas.

Constatamos igualmente a emergência de duas formulações que contribuíram para mudanças na organização da teoria da frase: em Sotero dos Reis (1871) aparece com nitidez duas concepções importantes da frase, a expressão "Frase Portuguesa" como a indicar as construções próprias que identificam o espírito da língua e a noção de período gramatical como construto que dá materialidade ao discurso; a outra formulação advém de Júlio Ribeiro (1885), na qual destacamos a retomada do termo chave "Sentença" e seu posicionamento em seu favor, em detrimento do termo "período", também sua proposta de constituição bimembre da sentença (sujeito + predicado), bem como a melhor formulação conceitual do termo frase - "é uma combinação de palavras coordenadas entre si, mas sem formar sentido perfeito"; tal formulação é resultado da influência da gramaticografia inglesa na qual o termo frase nomeia o nível linguístico intermediário entre a palavra e a sentença (LÉON, 2003).

O que preocupava sobremaneira estes gramáticos era a justa expressão do pensamento, no que baseavam sua produção gramatical, fundamentados na tradição de estudos da linguagem ocidental, na PALAVRA como elemento linguístico primordial. A concepção de gramática que predominava neste período é a que a considera como arte em continuidade com a tradição greco-latina (FÁVERO, 2001); como nesta, a frase é tomada como contexto onde os elementos linguísticos fundamentais, as palavras, aparecem em suas relações e sentidos, portanto, como os instrumentos necessários para a prática da arte gramatical. 


\subsection{A frase na gramaticografia brasileira: Século XX}

Nos princípios do século $\mathrm{XX}$, "a dialética da gramática como arte e como ciência” (CAVALIERE, 2014, pp. 11-2) já se encontrava impressa nos textos linguísticos brasileiros como efeito do movimento histórico-comparativo da gramática científica que impunha como tarefa tanto pesquisar como ensinar a língua. Surge assim no Brasil dos novecentos uma concepção de gramática que, no âmbito das obras mais representativas, busca coadunar a atividade de pesquisa com a atividade de ensino, no sentido de, ao menos, não se apresentarem regras sem fundamentação teórica (id., p. 12).

Este impulso para o tratamento empírico dos fatos linguísticos, em detrimento do especulativo, que fora praticado durante boa parte do século XIX pelos gramáticos que seguiam os cânones racionalistas da gramática filosófica, permitiu que ao longo do século XX crescesse progressivamente a preocupação com uma fundamentação teórica que fosse válida a partir da análise dos fatos da língua colhidos empiricamente, portanto, uma preocupação também metodológica e, consequentemente, terminológica. Segundo Cavaliere (ibid., p. 31) taxionomia, descrição e análise do fato linguístico constituem a tríade metodológica que sofreu mudanças com o advento da gramática científica e que, a partir dela, foi aplicada às propostas pedagógicas de então.

O que se seguiu a este movimento foi a crescente especialização dos estudos linguísticos, por meio de sua institucionalização com a criação das Faculdades de Filosofia (1930), a promulgação da Nomenclatura Gramatical Brasileira (1959) e a emergência de um novo paradigma de estudos da linguagem (Linguística) e a diversificação de programas de pesquisa no interior deste paradigma (Estruturalismo, Gerativismo, Semiótica).

De modo a compreendermos a frase neste contexto, acompanhemos a consolidação dos conceitos envolvidos na teorização da frase em dicionários de prestígio no período. Frase não é termo da gramaticografia oficial, no entanto, está ele presente nos manuais, o que evidencia que algum aspecto da linguagem ele reveste. A partir do Dic. de Moraes Silva (1831), monolíngue e não especializado, passamos ao Dic. Prosódico de Carvalho \& Deus (1885), para chegarmos ao Dic. Gramatical de Ribeiro (1906), um dos mais prestigiados em sua época, e ao Dic. de Filologia e 
Gramática de Mattoso (1970), pretendemos esboçar a rede conceitual presente em cada um deles de modo a evidenciar o problema da equivalência terminológica em questão. Chamou-nos a atenção, o fato de não haver em Ribeiro (1906), por exemplo, um verbete para o termo frase, ainda que ele esteja presente como termo corrente no discurso do autor. Ex.: A classificação no domínio especial da sintaxe, isto é, da frase, estuda-se na Analise lógica (V. Proposições) (RIBEIRO, 1906: 66).

No Quadro a seguir, elaborado por nós, vemos como se articulam as definições dos termos que de algum modo podem equivaler ao termo frase nos dicionários consultados.

\begin{tabular}{|c|c|c|c|c|}
\hline \multicolumn{5}{|c|}{$\begin{array}{c}\text { QUADRO 4: Equivalência dos termos referentes ao conjunto frásico em dicionários } \\
\text { brasileiros }\end{array}$} \\
\hline & Moraes 4 ed. (1831) & $\begin{array}{l}\text { Carvalho; Deus } 5 \\
\text { ed. }(1885)\end{array}$ & Ribeiro 3 ed. (1906) & Câmara Jr. 4 ed. (1970) \\
\hline FRASE & $\begin{array}{l}\text { (combinação de } \\
\text { palavras) } \\
\text { - sentença }\end{array}$ & $\begin{array}{l}\text { (sentido completo) } \\
=\text { oração, período, } \\
\text { locução }\end{array}$ & 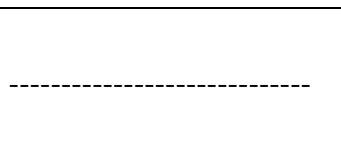 & $\begin{array}{l}\text { \{unidade de comunicação } \\
\text { linguística\} }\end{array}$ \\
\hline FRASEOLOGIA & \{uso de cada língua & $\begin{array}{l}\text { \{estudo de fr.; } \\
\text { construção de fr. }\end{array}$ & ------------------------------- & \{estudo/frases feitas \\
\hline PROPOSIÇÃO & Sujeito + Predicado & $\begin{array}{l}\text { \{expressão } \\
\text { verbal/juízo }\end{array}$ & $\begin{array}{l}\text { \{conjunto de palavras } \\
\text { coordenadas/representem } \\
\text { um juízo }\end{array}$ & \\
\hline ORAÇÃO & $=$ proposição/sentença & $\begin{array}{l}\text { = discurso, fala, } \\
\text { proposição } \\
\text { gramatical, } \\
\text { expressão dum juízo }\end{array}$ & $=$ proposição & $\begin{array}{l}\text { \{Frase elementar, livre ou } \\
\text { dependente, em que um } \\
\text { propósito definido de } \\
\text { comunicação linguística } \\
\text { se formula num esquema } \\
\text { discursivo, prestando-se a } \\
\text { uma análise dos } \\
\text { constituintes, a um tempo } \\
\text { formal e mental. }\end{array}$ \\
\hline PERÍODO & $\{$ retórica/discurso & $\begin{array}{l}\text { \{certa parte do } \\
\text { discurso /sentido } \\
\text { completo }\end{array}$ & $\begin{array}{l}=\text { proposição (sentido } \\
\text { perfeito) }\end{array}$ & $\begin{array}{l}\text { \{Conjunto frasal, cuja } \\
\text { enunciação termina por } \\
\text { uma pausa conclusa, } \\
\text { assinalada na escrita pelo } \\
\text { sinal de ponto }\end{array}$ \\
\hline SENTENÇA & $=$ proposição & 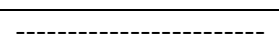 & $=$ proposição & $=$ frase, oração \\
\hline
\end{tabular}




\begin{tabular}{|c|c|c|c|c|}
\hline CONSTRUÇÃO & [colocação & |------------------------- & \{ordem de colocação & $\begin{array}{l}\text { \{reunião dos elementos } \\
\text { formais linguísticos no } \\
\text { vocábulo, na locução, na } \\
\text { oração e assim por diante. } \\
=\text { construção sintática }\end{array}$ \\
\hline ENUNCIADO & [pensamento & $\begin{array}{l}=\text { proposição, } \\
\text { asserção }\end{array}$ & |-------------------------------- & ---------------------------------- \\
\hline
\end{tabular}

- não equivalente; $\{$ campo de aplicação ou traços funcionais; = termo equivalente; [ processos envolvidos; sem definição; ( ) traço da definição.

Observemos ainda, no eixo horizontal, os traços conceituais dos termos da cadeia terminológica FRASE-ORAÇÃO-PERÍODO:

Frase: este termo aponta para contextos comunicativos e estilísticos; combinação de palavras que não faz uma sentença em Moraes Silva; caracteriza-se por apresentar sentido completo em Carvalho \& Deus; e constitui unidade de comunicação em Mattoso.

Oração: este termo aponta para o contexto da gramática e da lógica; equivale à proposição, que por sua vez estrutura-se em sujeito e predicado; constitui para Carvalho \& Deus proposição gramatical, manifestação da fala e expressão do juízo; para Ribeiro equivale à proposição, sendo este o termo chave de sua análise da frase, pois é formada por palavras coordenadas e expressam o juízo; caracteriza-se em Mattoso por um propósito definido e por ser passível de uma análise de seus constituintes.

Período: é termo do âmbito da retórica, do discurso retórico; apresenta sentido completo em Carvalho \& Deus e sentido perfeito em Ribeiro, para este, equivale igualmente à proposição; em Mattoso constitui um conjunto frasal, caracterizado por pausa final na oralidade e por pontuação na escrita.

O termo FRASE adquire certo rigor terminológico com Mattoso Câmara; tal fato resulta do novo campo epistêmico que Mattoso se esforça por implantar no Brasil, o da Linguística, em suas vertentes descritiva e geral. Pelo fato de nós quando "falamos ou escrevemos, exprimimo-nos por meio de FRASES (CLP-G, 1945, p. 5)" ou, do mesmo modo, por nós "falarmos ou escrevermos por meio de conjuntos de palavras, chamados 
FRASES (TAL, 1956, p. 5)"; ou ainda que "partindo da distinção fundamental entre língua e discurso, é-nos fácil definir a FRASE, dizendo com GARDINER, que é ela a unidade do discurso, e resulta da aplicação dos elementos da língua para a manifestação, pela linguagem, de estados psíquicos individuais (LLG-IX)" chegamos a vislumbrar a guinada de perspectiva que sofre o campo dos estudos da linguagem, da gramática como arte/ciência para a linguística. No entanto, apenas na década de 1960 a perspectiva linguística tornar-se-á predominante; ainda assim, não será a concepção mattosiana da frase a que então vigorará.

A concepção da frase como unidade da linguagem teve como destacado adepto, no âmbito da gramaticografia brasileira, o gramático Mario Pereira de Souza Lima que organizou sua Gramática Expositiva da Língua Portuguesa (1937) a partir de tal postulado. Foi ele inspirado, segundo Souza (2011), a conceituar a frase como unidade fundamental do discurso pela obra La oración y sus partes (1920) de Rodolfo Lenz; outro estudioso que também acolheu esta concepção foi Sousa da Silveira que, como elaborador do Programa de Português e das Instruções Metodológicas (Portarias $n^{\text {os }} 170$ e 172 de 11/07/1942 e 15/07/1942), instituiu que o programa de português das quatro séries ginasiais começasse com a análise do período simples.

Souza Lima (1937, apud SILVA, 2014) considera que a unidade da linguagem assenta-se na frase - não na palavra -, motivo pelo qual, em sua opinião, o ensino gramatical deve partir da estrutura oracional (proposição), para se chegar às demais partes do discurso; daí ter alterado, deliberadamente, a disposição tradicional da matéria gramatical. Em suas palavras: "a unidade da linguagem não é a palavra isolada, mas a frase, ou seja, a expressão linguística de uma representação global considerada em seu conjunto (LIMA, 1937, apud SOUZA, 2011, p. 24)". Busca então tratar das estruturas frásicas, às quais dá o nome de orações analíticas, orações sintéticas e fragmentos de oração, reconhecendo - no rastro de Rodolfo Lenz - que a palavra, por ser imprecisa em si mesma, somente adquire sentido quando inserida num conjunto discursivo. Suas considerações preliminares terminam com a observação de que as orações - cuja definição, aliás, é colhida na obra de Andrés Bello - se dividem em três espécies (exclamativas, declarativas e interrogativas), as quais podem aparecer isoladamente ou unidas, dentro de um conjunto discursivo mais amplo denominado período. Do que podemos extrair as seguintes concepções: 
Frase: expressão linguística de uma representação global.

Oração: estrutura frásica.

Período: conjunto discursivo mais amplo.

A gramática escolar de Mattoso Câmara, publicada em conjunto com uma Antologia, esta de responsabilidade de Rocha Lima, fazia parte do Curso da Língua Pátria; estava ela organizada em dois volumes: o primeiro dirigido às $1^{\mathrm{a}}$ e $2^{\mathrm{a}}$ séries ginasiais saiu em 1944; o segundo dirigido às $3^{\mathrm{a}}$ e $4^{\mathrm{a}}$ séries saiu em 1945. Como veremos em maiores detalhes no Capítulo 3, o pensamento linguístico de Mattoso já apresenta neste momento os contornos que o caracterizarão ao longo de tão profícua carreira: fundamentação num sólido e atualizado conhecimento da novel ciência linguística; priorização da Língua Portuguesa como objeto de aplicação dos conhecimentos da ciência linguística; e preeminência da visão sincrônica dos fatos linguísticos.

Hackerott \& Almeida (2014) destacam os seguintes pontos doutrinários da gramática de Mattoso Câmara: a importância dada à sintaxe, que abre os dois volumes referidos; o atrelamento da noção sistêmica da língua, que permite sua decomposição em partes comutáveis, à função comunicativa; a língua portuguesa como objeto de análise tanto em sua modalidade oral (fala) como na escrita; a escolha da variedade culta para descrição, ainda que reconheça alguns usos populares; o ater-se ao aspecto descritivo da tarefa gramatical. Os autores ressaltam também o fato de que, de modo geral, a orientação teórica adotada por Mattoso em sua gramática escolar é a mesma adotada nos livros direcionados ao público especializado ou ao ensino superior ${ }^{51}$.

Mattoso Câmara (1944) afirma em sua gramática:

- Quando falamos ou escrevemos, exprimimo-nos por meio de FRASES. A frase pode ser brevíssima, constituída até por uma única palavra, ou pode ser longa e

${ }^{51}$ Como exemplo desta postura os autores apontam o tratamento do grau dos substantivos como um processo derivacional e não como flexão. 
complexa. // Dá-se o nome de ORAÇÃO a uma frase que se apresenta com uma UNIDADE DE SENTIDO e pode ser fracionada em duas partes, as quais se chamam SUJEITO e PREDICADO. // A ANÁLISE SINTÁTICA consiste em separar as orações de uma frase, e, em cada oração, distinguir o SUJEITO e o PREDICADO, e, neste, o VERBO e os COMPLEMENTOS, que integram o sentido da frase.

O modelo de tratamento da frase que podemos extrair daí, ao mesmo tempo que situa a frase num contexto de uso (quando falamos e escrevemos) restringe-se à análise do tipo oracional (sujeito e predicado), como suas congêneres gramáticas pedagógicas, não chegando a incluir o período, em sua exposição, como um construto de tipo analisável gramaticalmente. O período aparecerá como tal no âmbito retórico do Manual de expressão oral e escrita (1978) no capítulo intitulado "A escritura da frase" organizado nos tópicos: o período, a articulação no período, a técnica do período curto, subordinação por oração reduzida e construção psicológica da frase.

Podemos, a título de controle conceitual, relacionar as concepções apresentadas por Mattoso Câmara em seu dicionário com as concepções que orientaram sua produção de instrumentos linguísticos: gramática, manual de expressão e manual científico. Assim, na gramática o termo Oração nomeia a "frase elementar" com unidade de sentido e analisável em seus constituintes, a um tempo formais e mentais, por meio da análise sintática; no manual de expressão, o termo Período é tomado como "conjunto frasal" que contêm ou um pensamento complexo ou um pensamento uno, em suma, é no período que se revela a articulação de pensamentos ${ }^{52}$ - tais articulações são evidenciadas pela análise lógica, que tem por objetivo identificar as relações entre as frases e os pensamentos; por fim, no manual científico temos a frase como "unidade de comunicação linguística" caracterizada linguisticamente dentro do discurso a partir do propósito definido e do tom frasal que tal propósito enseja, teoricamente emerge como elemento da língua a partir da criação de padrões estruturais, criação feita "conforme a língua, por uma pauta peculiar, dependente das categorias gramaticais e dos morfemas de que a língua dispõe (CÂMARA JR., 1974, p. 166)" - a análise linguística é

\footnotetext{
${ }^{52}$ Mattoso Câmara (1986, p. 70) elenca quatro tipos de articulação do pensamento dentro do período: concatenação, contraste, explicação e subordinação.
} 
responsável, assim, por dar conta do material linguístico que se encontra articulado como enunciação frasal.

A gramaticografia brasileira do começo do século XX não fez uso das reflexões mattosianas no sentido de consolidar um modelo de tratamento da frase que se refletisse numa terminologia aceite e em conceitualizações concordantes. Vejamos, a partir da análise do lugar da frase na sinopse gramatical de algumas gramáticas do período, os encaminhamentos dados no sentido de superar a confusão conceitual-terminológica diagnosticada por Hauy (1983):

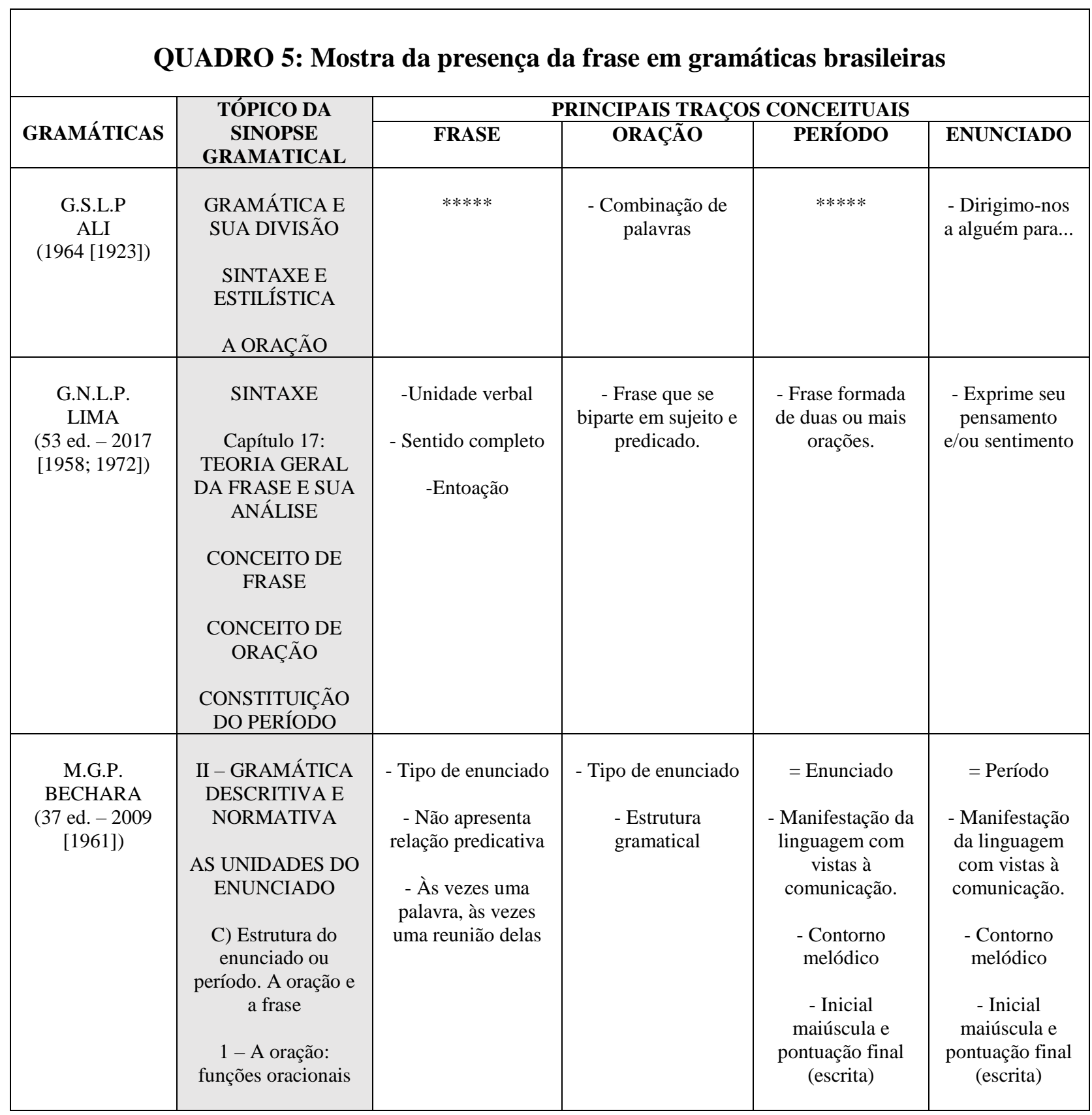




\begin{tabular}{|c|c|c|c|c|c|}
\hline & $\begin{array}{c}2 \text { - Orações } \\
\text { complexas e grupos } \\
\text { oracionais: A } \\
\text { subordinação e a } \\
\text { coordenação. A } \\
\text { justaposição } \\
\text { 3- As chamadas } \\
\text { orações reduzidas } \\
4-\text { As frases: } \\
\text { enunciados sem } \\
\text { núcleo verbal }\end{array}$ & & & & \\
\hline $\begin{array}{c}\text { G.P.C } \\
\text { CUNHA } \\
\text { (s. d. [1970]) }\end{array}$ & $\begin{array}{l}\text { 6. A oração e seus } \\
\text { termos } \\
\begin{array}{c}\text { FRASE, ORAÇÃO, } \\
\text { PERÍODO. }\end{array} \\
\begin{array}{c}\text { A frase e sua } \\
\text { constituição. }\end{array} \\
\text { Frase e oração. } \\
\text { Oração e período. } \\
\begin{array}{c}\text { 17. O período e sua } \\
\text { construção }\end{array}\end{array}$ & $\begin{array}{l}\text { - Enunciações de } \\
\text { sentido completo } \\
\text { - Unidade da fala } \\
\text { (verdadeira) }\end{array}$ & $\begin{array}{c}\text { * presença da forma } \\
\text { verbal }\end{array}$ & $\begin{array}{l}\text { - Frase organizada } \\
\text { em orações }\end{array}$ & $\begin{array}{c}\text { - Enunciação } \\
\text { - Fala }\end{array}$ \\
\hline
\end{tabular}

* conceituação indireta / = equivale a / - traço significativo / ***** sem definição

Predomina neste corpus a cadeia terminológica FRASE-ORAÇÃO-PERÍODO, cadeia esta que resultou de um progressivo desenvolvimento histórico de diferenciação dos termos aí envolvidos e cujos marcos podemos sumariar em: presença dos termos ainda indiferenciados em Barbosa (1822), uso do termo "período gramatical” em Reis (1871), a proposta por Caneca (1876) dos três modos de considerar a oração (construção, significação e número), explicitação da definição do termo frase em Júlio Ribeiro (1871), a tomada da frase como unidade da linguagem em Souza Lima (1937) e a fundamentação teórica na ciência linguística moderna de Mattoso Câmara (1942). Neste percurso observamos o progressivo abandono do termo proposição, ainda que Maciel (1894) o tenha tomado como preferível a todos os outros, por ser ele "mais geral e estar mais de acordo com as teorizações da lógica e simplificar mais a aprendizagem”. Ilustram ambos os movimentos, consolidação da cadeia terminológica e abandono do termo proposição, a passagem de uma visão lógico-filosófica para uma visão linguística dos fenômenos idiomáticos na tradição brasileira de estudos da linguagem.

Emerge deste conjunto de eventos, como possíveis desenvolvimentos, duas perspectivas de conceituação que vão, de algum modo, repercutir na gramaticografia 
escolar do século XXI: a primeira advém da preferência pelo aspecto frasal em Rocha Lima ([1958] 2017) e enunciativo em Bechara ([1961] 2009). Por aspecto frasal entendemos não só o uso do termo frase como termo chave para compreensão da cadeia conceitual-terminológica, mas também a concepção da frase como "unidade verbal, com sentido completo e entoação", ou seja, como um construto dissociado de seu uso efetivo nas situações comunicativas. Igualmente, o aspecto enunciativo se revela em Bechara na medida em que utiliza o termo enunciado na definição dos elementos da cadeia conceitual-terminológica, tomando-o, em princípio, como termo que identifica o fenômeno geral, que se apresenta sob as espécies frase, oração e período. Neste último, observamos também a forte presença do pensamento linguístico de Eugênio Coseriu, o qual está alicerçado na convicção de que "el lenguaje se presenta concretamente como una actividad humana específica y fácilmente reconocible, a saber, como hablar $o$ 'discurso "53 (COSERIU, 1991, p. 13)', ou nos termos que propomos, em sua dimensão enunciativa.

No entanto, a despeito das questões conceituais, o que sobressai como unidade de análise gramatical é sempre a oração, secundada pelo período. Esta centralidade da oração como elemento de análise é devida a seu caráter de estrutura puramente linguística. Diferente da frase e do enunciado, que apresentam certa inter-relação com o entorno e com a situação, contém ela linguisticamente em si "todos os dados para a comunicação do seu assunto, sem necessidade da mímica e da situação para completálos" (CÂMARA JR., 1970, p. 187).

53 Traduzimos: "a linguagem se apresenta, concretamente, como uma atividade humana específica e facilmente reconhecível, a saber, como fala ou 'discurso"”. 


\section{CAPÍTULO 3}

\section{A FRASE: seu lugar no horizonte de retrospecção de Mattoso Câmara}

Nos capítulos anteriores, procuramos evidenciar as representações da frase nos âmbitos da filosofia e da gramática; buscamos igualmente, a partir da diversidade de suas emergências, recolher elementos que nos permitissem construir uma permanência ou identidade dos conhecimentos (AUROUX, 2006) acerca do fenômeno linguístico frase. Este objetivo carece de uma última faceta, a saber, a linguística. Consideramos, para tanto, o trabalho do eminente linguista brasileiro, Joaquim Mattoso Câmara Jr. (1904 - 1970), pois nele encontramos uma discussão aprofundada da ideia de frase com base nesta vertente de estudos.

Entendemos com Delesalle (1974, p.45) que a frase é de alguma forma uma "dobradiça" entre língua e discurso, constituindo, por isso, um domínio privilegiado para o estudo das relações entre morfossintaxe, atos de fala e registros da língua. Situaremos o trabalho mattosiano, a partir de seu Horizonte de Retrospecção no que toca à frase, na esteira da emergência das teorias enunciativas de final do século XIX e início do XX.

Neste capítulo chegamos ao ponto de maior inflexão de nosso relato; ocupamonos nos dois capítulos anteriores, como vimos, dos fatos referentes à emergência e às representações da ideia de frase num plano mais amplo e geral. Ao abordarmos a gramaticografia brasileira do começo do século XX, entrevimos o importante papel desempenhado por Mattoso Câmara na tradição de estudos da linguagem no Brasil, bem como o lugar de destaque que a teoria da frase ocupa nas reflexões linguísticas mattosianas.

A perspectiva a partir da qual elaboramos esta parte de nosso trabalho vem informada pela visão de que a obra de Mattoso Câmara Jr.

não pode ser avaliada exclusivamente com base nos estudos que publicou sobre a língua portuguesa e sobre as línguas indígenas, mas como toda obra de cientistas que viveram e trabalharam fora dos grandes e médios centros científicos, tem de ser considerada em função das condições oferecidas pelo meio em que viveu e trabalhou, em relação a sua interação com esse meio e ao progresso do conhecimento que aí tenha contribuído para operar, assim como por referência à 
alteração que haja causado no próprio meio, especialmente através do desenvolvimento institucional na sua área de competência e atuação. Mattoso foi, sem dúvida, um pioneiro e, como tal, esteve praticamente isolado em grande parte de seu trabalho, experimentou a incompreensão e a hostilidade de seus colegas de formação tradicional e espírito conservador, e viu-se tolhido no seu justo anseio de maior participação na vida universitária (RODRIGUES, 2005, pp. 23-4).

Este depoimento de Rodrigues (2005) sintetiza de modo exemplar o que foi a trajetória acadêmica e profissional de Mattoso Câmara - eixo que escolhemos para organizar esta parte de nossa exposição -, sobretudo ao ressaltar as limitações do "centro científico" em que viveu e trabalhou, bem como seu caráter de "pioneiro" e de impulsionador do "progresso do conhecimento" na área dos estudos linguísticos entre nós. A biografia intelectual de Mattoso Câmara está por ser escrita; nosso objetivo aqui não é avançar neste sentido, senão o de encontrar os traços mais relevantes do seu pensamento no que toca à reflexão sobre a teoria da frase.

Em 3.1 apresentaremos breve relato da emergência das teorias enunciativas; em 3.2 apresentaremos o percurso acadêmico e profissional de Mattoso Câmara de modo a mapearmos as áreas que mais lhe interessaram no campo da ciência linguística; em 3.2 partindo do conceito de sistema científico (SC), exposto no capítulo 1, apresentaremos as problemáticas institucionais e doutrinárias com que Mattoso Câmara se deparou ao longo de sua carreira; em 3.3 discorreremos sobre o programa linguístico de Mattoso Câmara a partir dos eixos LíNGUA e ESTILO que informam sua discussão sobre a teoria da frase; por fim, 3.4 apresentaremos os contornos do seu horizonte de retrospecção (HR).

\subsection{Breve panorama da emergência das teorias enunciativas}

Em Léon (2003), tal como para a frase, encontramos o percurso histórico do termo ENUNCIADO: até o final do século XVIII era equivalente à proposição, a partir do século XX adquiriu o sentido que lhe empresta as teorias enunciativas, porém em nada

representando qualquer continuidade com o sentido anterior. Trata-se, para a historiadora, de dois sentidos funcionando em paralelo. Para o período anterior às teorias enunciativas remetemos a este seu texto e ao número, dirigido por Simone 
Delesalle, da revista Histoire Épistémologie Langage ${ }^{54}$ (1986) dedicado à história das concepções de enunciação.

Interessa-nos registrar aqui apenas a emergência das teorias enunciativas, sintetizado no quadro a seguir:

\begin{tabular}{|c|c|c|}
\hline \multicolumn{3}{|c|}{ QUADRO 6: EMERGENCIA DAS TEORIAS ENUNCIATIVAS ${ }^{55}$} \\
\hline AUTOR & DEFINIÇÃO & OUTRAS CONSIDERAÇÕES \\
\hline $\begin{array}{l}\text { Henri Weil } \\
(1844)\end{array}$ & $\begin{array}{l}\text { Condição essencial do discurso que forma } \\
\text { como que o lugar onde se reencontram } \\
\text { aquele que fala e aquele que escuta. }\end{array}$ & \\
\hline Wegener (1885) & $\begin{array}{l}\text { Postula que a função da linguagem não é } \\
\text { exprimir ou representar os pensamentos, } \\
\text { mas influenciar, causar um efeito no } \\
\text { outro. } \\
\text { A unidade de análise da linguagem é o ato } \\
\text { considerado como ação orientada a um } \\
\text { objetivo. }\end{array}$ & $\begin{array}{l}\text { Linguística histórica } \\
\text { Continuador: Karl Bühler. } \\
\text { Wegener - Bühler - Jakobson - } \\
\text { Benveniste (tem se ocupado da } \\
\text { comunicação como interação através da } \\
\text { análise dos dêiticos). }\end{array}$ \\
\hline $\begin{array}{l}\text { Alan Gardiner } \\
\text { (1932) }\end{array}$ & $\begin{array}{l}\text { "a enunciação tem todas as características } \\
\text { da ação e (...) a diferença entre conteúdo } \\
\text { proposicional e força ilocucionária." }\end{array}$ & $\begin{array}{l}\text { Contemporâneo de Bühler. } \\
\text { Firth } \\
\text { Tradição de Ogden e Richards; e de } \\
\text { Malinownski, fundador da escola } \\
\text { "contextualista" inglesa. }\end{array}$ \\
\hline $\begin{array}{l}\text { Bally e } \\
\text { Sechehaye } \\
(1932)\end{array}$ & $\begin{array}{l}\text { Em sua "estilística" (1909), protoforma de } \\
\text { sua teoria da enunciação (1932), Bally } \\
\text { pretende estudar a língua falada em seus } \\
\text { conteúdos afetivos e subjetivos; e a } \\
\text { linguagem enquanto expressão dos } \\
\text { sentimentos e instrumento de ação. } \\
\text { Pretende o estudo sistemático de certos } \\
\text { tipos expressivos, de certos atos de fala, } \\
\text { de tal modo que distinga as funções }\end{array}$ & $\begin{array}{l}\text { Decidem estudar sistematicamente o } \\
\text { domínio da "parole". } \\
\text { "É a partir dele que o enunciado começa a } \\
\text { concorrer com a frase. A dimensão lógica } \\
\text { da frase não existe isoladamente. Nela } \\
\text { subjaz a expressão da ordem como } \\
\text { afirmação do dictum a que se reúne as } \\
\text { modalidades (modus) que determinam a }\end{array}$ \\
\hline
\end{tabular}

${ }^{54}$ Ver Histoire Épistémologie Langage, tome 8, fascicule 2, 1986. Histoire des conceptions de l'énonciation.

${ }^{55}$ Adaptado de Léon (2003). 


\begin{tabular}{|l|l|l|}
\hline & $\begin{array}{l}\text { intelectual, afetiva e social. Estas funções } \\
\text { se manifestam por estilos diferentes, ou } \\
\text { seja, por um léxico, uma sintaxe e uma } \\
\text { entoação específica. }\end{array}$ & dimensão linguística da enunciação.” \\
\hline
\end{tabular}

De acordo com Léon (2003, p.13) as fontes das teorias enunciativas encontramse no século XIX em diversas tradições: na crítica e continuação dos Ideólogos, na linguística histórica alemã e francesa e, mais recentemente, no contextualismo e na filosofia analítica inglesas.

Veremos ao longo deste capítulo a presença marcante no Horizonte de Retrospecção de Mattoso Câmara, quando trata da frase, dos nomes de Gardiner, Bally e Sechehaye, importantes na elaboração original das teorias enunciativas. A partir desta evidência é que aventamos a hipótese de que a discussão a respeito da questão da frase em Mattoso parte de uma concepção linguística de base enunciativa, a que agrega o aspecto estrutural dos patterns sapirianos e o aspecto funcional do Círculo Linguístico de Praga.

É, portanto, a nosso ver, no percurso histórico das concepções enunciativas que devemos localizar o Mattoso dos capítulos X e XI dos Princípios de linguística geral (1975), ainda que seja imperioso destacar os rearranjos a que se viu compelido por suas vastas leituras e aprofundados estudos. Antes, porém, acompanhemos o percurso acadêmico e profissional de nosso personagem.

\subsection{Mattoso Câmara: percurso acadêmico e profissional}

Mattoso Câmara nasceu em 13 de abril de 1904; após uma vida de estudos profícuos e de intenso trabalho, veio a falecer em 4 de fevereiro de 1970. Os estudos primários e secundários realizou-os em casa, com professores particulares, destacandose aí a figura do professor Jonatas Serrano. Cabe explicitar, com Schmidt (2004, p. 196), que Serrano foi um intelectual entusiasta do discurso da Escola Nova. Esse entusiasmo é revelado, por exemplo, pela importância que dá à educação como forma de se preparar a criança e o jovem para a vida; pela crença no ensino centrado na 
criança e não no professor e pela valorização que faz do método como maneira de se melhorar o ensino.

Antes de dedicar-se inteiramente ao estudo da linguagem e da língua portuguesa, Mattoso Câmara obteve formação em arquitetura pela Escola Nacional de Belas-Artes, em 1927, e de direito pela então Universidade do Rio de Janeiro, em 1932. Como preparação para a carreira docente fez cursos de aperfeiçoamento e especialização, tanto no Brasil quanto no exterior. Assim, em 1937 frequentou o curso de filologia latina e neolatina na antiga Universidade do Distrito Federal, ministrado pelo professor visitante George Millardet (Sorbonne). Em 1943, com bolsa da Fundação Rockfeller, frequentou vários cursos de linguística nos Estados Unidos; ao regressar ao Brasil, doutorou-se em 1949, com a tese Para o estudo da fonêmica portuguesa, aprovada com distinção, e em 1952 obteve o título de livre-docente de língua portuguesa com a tese Contribuição para uma estilística da língua portuguesa (UCHÔA, 1975).

A atuação profissional de Mattoso Câmara deu-se em escolas de nível secundário, públicas e particulares, como a Escola de Comando e Estado-Maior da Aeronáutica e o Instituto Rio Branco, em universidades públicas e particulares, em associações de linguística e de filologia, em eventos científicos e como autor de manuais e livros pedagógicos e científicos. Matos (1973, p. 73) elenca a partir de tão variados contextos os papeis vividos pelo "insigne linguista”. São eles: Mattoso-colega, Mattoso-professor, Mattoso-conferencista e Mattoso-autor.

As qualidades manifestadas por Mattoso Câmara em cada um destes papeis podem ser avaliadas da seguinte forma: como colega, afirma Matos (ibid., p. 74), dispensava sempre uma atenção e carinho especiais aos colegas de magistério, o que levou a ser respeitado como um verdadeiro conselheiro, podendo insistir, assim, junto aos recém-iniciados no ensino de linguística, que a leitura dos clássicos da literatura especializada deveria ser uma obrigação, bem como a necessidade de um bom domínio de línguas estrangeiras para uma visão verdadeiramente universal da literatura linguística; a faceta professoral de Mattoso é a mais ressaltada nos textos que o homenageiam ou avaliam seu perfil intelectual (UCHÔA, 1975; RODRIGUES, 2005; CAVALIERE, 2014; ALTMAN, 1998), para Matos (1973, p. 75) a presença, quase invisível a seus alunos, de um roteiro ou sinopse dos temas a serem desenvolvidos em aula era uma demonstração do rigor que Mattoso sabia imprimir às suas atividades 
didáticas, bem como de seu intuito de facilitar a apresentação, nem sempre fácil, de conceitos fundamentais da linguística; como conferencista Mattoso Câmara apresentava, ainda segundo Matos (ibid.), por um lado, a segurança de seus conhecimentos, oriundos de uma perspectiva ampla e multifacetada sobre o fenômeno linguagem, por outro, sua capacidade de estimular nos ouvintes uma reflexão instantânea inconfundível; na concepção de Matos (1973, p. 76), a faceta mais difícil de ser avaliada é a do Mattoso-autor, sobretudo a respeito de sua influência sobre professores de linguística no Brasil, ainda assim seus trabalhos Princípios de linguística geral, Dicionário de filologia e gramática e Problemas de linguística descritiva constituíram, em sua visão, verdadeiros marcos no estabelecimento de uma bibliografia linguística básica, indispensável e inspiradora para os novos docentes de linguística brasileiros.

No século XXI, novas perspectivas de compreensão da obra de Mattoso Câmara têm surgido, sobretudo na perspectiva da historiografia linguística. Por ocasião do centenário de seu nascimento, diversas publicações foram-lhe dedicadas; destaquemos o volume 20 da revista DELTA: Documentação de Estudos em Linguística Teórica e Aplicada, e o volume de números 27/28 da revista Confluência, ambos publicados em 2004. Nelas grande número de estudiosos apresenta reflexões sobre o legado de conhecimentos deixado por Mattoso Câmara.

No reexame de nossa tradição de estudos da linguagem, promovido pela nova disciplina da Historiografia Linguística, Mattoso Câmara tem papel de destaque, não apenas pelas obras que deixou, mas também por sua atuação profissional e seus posicionamentos teóricos. Ele surge, por exemplo, como figura central nas primeiras disputas pelos espaços acadêmicos então disponíveis, travadas entre a Filologia e a Linguística. Na análise de Altman (1998, p. 106):

As primeiras reações contra Mattoso - e, em consequência, contra o tipo de enfoque que ele propunha para os estudos linguísticos - eram de natureza pessoal e advinham, provavelmente, além do temperamento do próprio Mattoso, do fato dele não possuir (formalmente) o tipo de formação autorizado: filológico e/ou literário. // Este primeiro embate entre Filologia e Linguística nas recém-criadas Faculdades de Filosofia, teria sido, portanto, de ordem social, de interesse institucional e, até mesmo, de incompatibilidades pessoais. 
Aparece também como introdutor da linguística estrutural no Brasil (VALLE, 2004; COELHO, 2004). Sobre este aspecto, Cavaliere (2014, p. 143) argumenta que o veio inovador em Mattoso diz respeito não só à aplicação do método estruturalista na descrição do português, mas na inauguração de uma fase em que começaram a despontar textos sobre linguística teórica descomprometidos com a atividade descritiva; com ele surge uma senda efetivamente inovadora, a de tocar as questões sobre a linguagem humana em plano eminentemente teórico.

Tanto Cavaliere (2014) quanto Altman (1998) advertem que Mattoso não era um teórico na acepção do termo, mas um divulgador da teoria estruturalista. Nas palavras desta última:

\begin{abstract}
Mattoso não propôs, nos Princípios, uma teoria própria, ao contrário, inaugurou uma prática que traria importantes conseqüências para as gerações que o sucederam, que consistia em derivar idéias linguísticas da Europa e dos Estados Unidos e aplicá-las na descrição do Português. A imagem da 'receptividade' da Lingüística brasileira foi, antes de mais nada, uma prática (ALTMAN, 1998, p. 102).
\end{abstract}

Este fato pode ser melhor compreendido se levarmos em conta que é com o próprio Mattoso que tem início a tradição linguística brasileira (NARO, 1976); como pioneiro, dedicou-se a estudar as principais correntes teóricas dos grandes centros científicos e a aplicar aquela que considerou como "a única abordagem frutífera no estudo da língua (ibid.)", a saber, os princípios do estruturalismo. Os grandes teóricos da linguística sempre tiveram por trás de si tradições cientificas e culturais robustas e ambientes socio-acadêmicos que possibilitavam a formação de grupos de força capazes de fomentar o pensamento teórico puro. Veja-se, neste sentido, a situação socioeconômica de um Saussure, o prestígio acadêmico dos teóricos norte-americanos, o grupo de força que cercou desde sempre um Jakobson. Mattoso realizou, a nosso ver, neste sentido, não só aquilo que nossa tradição permitiu, mas aquilo de que ela mais necessitava.

Mattoso Câmara testemunhou e, de algum modo, contribuiu para o processo de institucionalização da linguística no país; seja por meio dos cursos que ministrou na área ou através das associações que ajudou a criar. Para além de sua atuação como líder intelectual ou das rupturas que promoveu a partir de sua eventual retórica, aspectos historiográficos mais ao gosto da Historiografia (da) Linguística, interessa-nos, na 
perspectiva da História das Ideias Linguísticas traçar as linhas principais, a partir da produção de conhecimentos que tenha ensejado, do pensamento linguístico mattosiano.

Uchôa (1975) identifica na variada produção de Mattoso Câmara os seguintes centros de interesse, aos quais acrescentamos os títulos das obras principais que Mattoso a eles dedicou:

1) a linguística geral - Princípios de linguística geral (1ª ed., 1941);

2) o estudo da língua portuguesa - História e estrutura da Língua Portuguesa ( $1^{\mathrm{a}}$ ed., 1972, em inglês com o título The Portuguese language: history and structure).

3) os estudos estilísticos - Contribuição à estilística portuguesa (1 ${ }^{\text {a }}$ ed., 1953); Ensaios machadianos (1 ${ }^{\mathrm{a}}$ ed., 1962);

4) história das ciências da linguagem - História da linguística ( $1^{\mathrm{a}}$ ed., 1975);

5) as línguas indígenas brasileiras - Introdução às línguas indígenas brasileiras ( $2^{\mathrm{a}}$ ed. rev., 1965).

Tais centros de interesse vão se consolidar, cada qual, como visto, em um manual ou obra de relevância. Evidencia igualmente, este elenco de interesses e obras, que Mattoso Câmara pode ser visto como interessado nas várias manifestações do fenômeno linguístico, pretendendo mesmo abarcá-los num conjunto de obras que pudesse dar conta de uma linguística total, como propunha seu colega Eugenio Coseriu. Não afirmamos com isto que Mattoso houvesse elaborado tal projeto, apenas que a obra que deixou permite vislumbrar tal projeto como possível.

Observemos, por fim, na linha do tempo a seguir a interrelação do percurso profissional e científico de Mattoso Câmara com o percurso do processo de institucionalização dos estudos da linguagem no Brasil. 


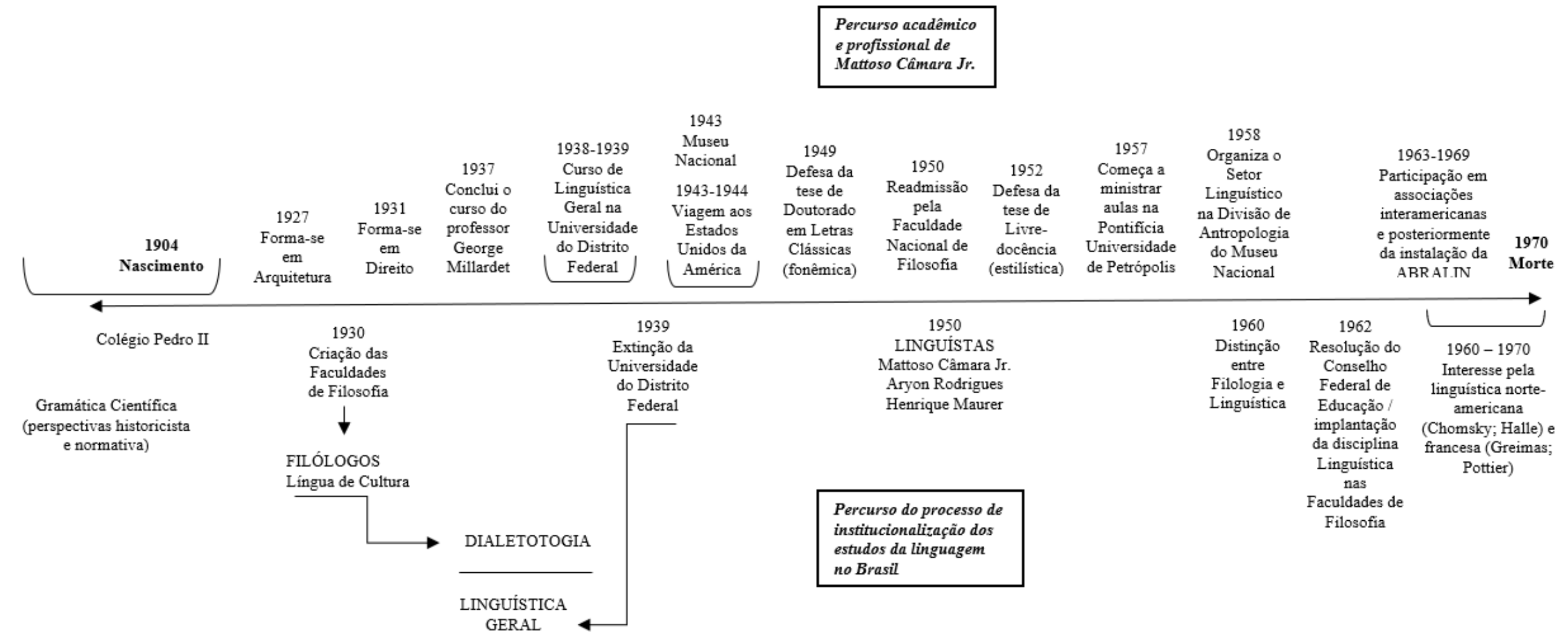

Linha do tempo: Atuação profissional de Mattoso Câmara Jr. em confronto com o desenvolvimento institucional da Linguística no Brasil 


\subsection{Mattoso e o Sistema Científico (SC) de sua época}

Para uma precisa contextualização de Mattoso Câmara é preciso considerar tanto o cenário internacional quanto o nacional num marco temporal de no mínimo cem anos. O alcance temporal das problematizações que lhe interessavam chega à Adolfo Coelho (1847-1919), no que ele chama de "a implantação da ciência da linguagem em Portugal" (CÂMARA JR., 1975, p. 198); para além deste marco, em sua opinião, não se encontra obra ou doutrina que inspire qualquer interesse científico no contexto luso-brasileiro, sendo este, aparentemente, o único interesse digno de estudo:

A situação anterior, assim superada, não cabe ser considerada aqui, pois se resume numa literatura didática, procurando repetir ditames que a tradição impunha, por mais de um século, no ensino da língua materna (CÂMARA JR., 1975, p. 198).

Mattoso situa no começo do século XIX europeu o surgimento da ciência linguística, daí a sua concepção de que é ela "uma ciência muito nova". Esta concepção da história da linguística vai, evidentemente, informar o espaço de atuação conquistado por Mattoso no meio intelectual brasileiro. Ao conceber a Linguística como uma ciência nova, reconhece, no plano doutrinário, as limitações e preconceitos de uma "linguística" velha; deste modo, contrapôs as propostas estruturais ao historicismo comparatista. Ao mesmo tempo, no plano institucional, tanto em seu viés político como em seu viés social, enfrenta obstáculos para firmar-se como linguista, tendo que, em seu início de carreira, contornar a não profissionalização da linguística e o ambiente acadêmico eminentemente filológico.

A primeira oportunidade de ouro para Mattoso veio com o convite feito por Sousa da Silveira para que ministrasse a disciplina de Linguística Geral no Curso de Letras da Universidade do Distrito Federal (UDF). Mattoso ministrou tal curso no curto período de dois anos (1938-1939). Desta primeira experiência ficaram as Lições de Linguística Geral, publicadas na Revista de Cultura já em 1939. A UDF, criada por um decreto municipal (Decreto 5.513, de 04 de abril de 1935), foi marcada desde o princípio pelo clima tenso de confrontação ideológica existente na época entre os intelectuais brasileiros. Os revolucionários de 1930 se haviam dividido entre a esquerda, que incluía Pedro Ernesto, prefeito do Rio de Janeiro, e a direita conservadora, muito 
mais poderosa, personificada pela Igreja Católica, por Francisco Campos e os chefes militares que cercavam Getúlio Vargas (SCHWARTZMAN, 2015, pp. 206-7).

Deste conflito resultou a extinção da Universidade do Distrito Federal por um decreto presidencial em 1939. Para Schwartzman (ibid., p. 211) a UDF foi fechada porque se chocava, institucional e ideologicamente, com os planos do novo ministro da Educação, Gustavo Capanema, de criar uma universidade nacional que se ajustasse ao projeto proposto alguns anos antes por Francisco Campos e que preenchesse os termos do acordo entre o regime de Getúlio Vargas e a Igreja Católica, cujo cumprimento Capanema considerava sua responsabilidade. Para substituí-la foi criada a Universidade do Brasil, cujo órgão central seria a Faculdade Nacional de Filosofia, Ciências e Letras, que concentraria as atividades de pesquisa científica. De acordo com Altman (1998, p. 103) esta faculdade não concedeu lugar especial à Linguística, o que retardou o processo de especialização profissional em Linguística, que mal havia se iniciado, e só seria retomado, efetivamente, duas décadas mais tarde, nos anos sessenta.

A tardia retomada deste processo explica em parte certo anacronismo doutrinário de Mattoso que se viu excluído da Faculdade e afastado não só de um público de linguistas em potencial, mas também de qualquer possibilidade de ascensão na carreira acadêmica (ALTMAN, 1998, p. 103). Quando na década de 60 se dá a profissionalização da Linguística a partir de sua inclusão oficial nos currículos de Letras por meio de resolução do Conselho Federal de Educação, o estruturalismo defendido por Mattoso já se encontrava desgastado, no ambiente nacional, ante os embates com o programa filológico e a falta de espaço institucional onde pudesse se desenvolver; na década de 70, quando o espaço da linguística já estava consolidado, o modelo teórico que se beneficiou do novo estado de coisas, espaço acadêmico e prestigio institucional, foi o gerativismo:

O estruturalismo foi negado como referencial válido, e os resultados a que, através [d]ele, se chegou, rejeitados. Algo mais, pois, estava em jogo nos anos setenta, além da busca da melhor solução descritiva para um conjunto de problemas fonológicos: o embate por uma outra concepção de ciência. Ao invés de quadros descritivos classificatórios, a proposição de regras transformacionais e a discussão sobre a ordem de aplicação destas regras foi proposta como o modo preferencial de fazer linguística 'moderna' (ALTMAN, 1998: p. 284). 
Diante da situação profissional adversa que se lhe apresentava na Universidade em 1939, Mattoso continuou professor de línguas em escolas secundárias e buscou um novo ambiente de produção de conhecimento especializado: foi trabalhar, em 1943, como voluntário, no Museu Nacional. De acordo com Rodrigues (2005), foi sua ligação com os antropólogos do Museu que lhe possibilitou a famosa viagem aos Estados Unidos (de setembro de 1943 a abril de 1944). Castro Faria (1965, p. 8), no texto introdutório ao Introdução às Línguas Indígenas Brasileiras, de Mattoso Câmara, resume da forma a seguir esta nova oportunidade com que Mattoso se deparou:

Em 1943 o mesmo Prof. MATtoso CAMARA era chamado por Heloisa Alberto TORRES para dar um curso especial de Lingüística aos etnólogos que iniciavam a sua carreira profissional no Museu. Nesse mesmo ano, com uma bôlsa da Fundação Rockfeller e o patrocínio dos diretores do Museu Nacional e da Faculdade Nacional de Filosofia o Prof. MAtToso CAMARA viajou para os Estados Unidos, onde permaneceu por nove meses, tendo trabalhado nas universidades de Columbia e Chicago. Em 1945 o Museu Nacional lançava uma nova série de publicações Publicações Avulsas - cujo primeiro número é exatamente um valioso ensaio de MATtoso CAMARA sôbre "Os Estudos Lingüísticos no Estados Unidos da América do Norte".

Os Estados Unidos, no período em que Mattoso esteve por lá, tinham se convertido no melhor destino para intelectuais russos e europeus, acossados pela Segunda Guerra Mundial, buscarem asilo. Intelectuais do porte de Jakobson e LéviStrauss encontravam-se atuantes naquele momento nas universidades norte-americanas. Mattoso (1945, p. 12) registra a presença daquele e de Henri Müller, Julien Bonfante, Wolf Leslau, Navarro Tomás e Ernst Cassirer. O interesse de Mattoso, no entanto, pelas correntes norte-americanas da linguística é anterior, visto que já em 1938 preparara a tradução do clássico Language, de Edward Sapir, onde busca, largamente, os fundamentos da sua própria concepção de linguística geral. Mattoso via em Sapir o grande iniciador da Linguística Geral norte-americana - ainda que tenha sido a corrente bloomfieldiana que tenha prevalecido como característica do pensamento linguístico norte-americano até o advento do gerativismo chomskiano.

Mattoso converte-se assim num primeiro elo entre a então moderna ciência linguística internacional e o nascente pensamento linguístico brasileiro. Para Cavaliere (2001, p. 51) os efeitos da presença de Mattoso no cenário linguístico brasileiro são verdadeiramente cruciais para os rumos enveredados no século XX, a partir da década de 1940. A força desta presença ecoa os contatos e estudos feitos por Mattoso em sua 
estada no Estados Unidos. No plano internacional, que é aquele no qual Mattoso se coloca enquanto linguista geral, o enquadramento epistemológico que predominava à época era o do chamado Estruturalismo; ele o define com Joseph Hrabák (1964) como sendo um ponto de vista epistemológico e não uma teoria ou um método. $\mathrm{O}$ estruturalismo é uma posição científica geral para todos os campos do conhecimento, também o estudo linguístico (CÂMARA JR., 1968, p. 5). Em seu O Estruturalismo Linguístico (1968) apresenta o seguinte elenco de estruturalismos com os quais estava familiarizado: o saussuriano (p.11) com seu desdobramento na sintagmática (p.15), o de Praga (p. 17), o sapiriano (p. 19) e seu concorrente, o mecanicismo bloomfildiano (22), a psicologia linguística estrutural de Gustave Guillaume (p. 26), a glossemática (p. 28), o funcionalismo linguístico (p. 30) e o diacrônico (p. 35).

Naro (1976, p. 86) julga equívoca a ideia de considerar Mattoso um propulsor da linguística norte-americana. Equívoco advindo, sobretudo, da circunstância externa dessa viagem de Mattoso aos Estados Unidos. O certo é que, ainda de acordo com Naro (ibid.), sua orientação básica é anterior àquela sua estada na América, a qual só serviu para reforçar sua inclinação pelo estruturalismo europeu, oferecendo-lhe a oportunidade de um contato direto com o Círculo de Praga através de Roman Jakobson, naquela época recentemente chegado à Nova Iorque. O próprio Mattoso, em texto no qual recenseia a Linguística Brasileira, aponta suas influências e localiza-se doutrinariamente no restrito quadro de linguistas brasileiros das décadas de 1940 e de 1950:

\footnotetext{
Inversamente a Mattoso Câmara, cujas tendências se ligam mais ao Círculo de Praga, aos conceitos saussurianos e à filosofia linguística de Sapir, Rodrigues afiliase ao mecanicismo de Bloomfield. Por sua vez, Silvio Elia mantém-se afastado de qualquer tipo de estruturalismo, quer americano quer europeu. Ele é principalmente um discípulo de Vossler, encarando a linguística como pensamento filosófico mais do que ciência empírica (CÂMARA JR., 1976, p. 50).
}

A primeira das ligações - com o Círculo de Praga - é, claramente, a última a ser assimilada pelo pensamento linguístico mattosiano; as outras duas - os conceitos saussurianos e a filosofia linguística de Sapir - aparecem já nas Lições de Linguística Geral: na primeira Lição (fevereiro de 1939), onde apresenta as linhas gerais da Linguística, apoia-se nos conceitos de SINCRÔNICA e DIACRÔNICA; na segunda Lição (março de 1939) apresenta a clássica distinção entre LíNGUA e DISCURSO; também nesta 
Lição, Sapir já aparece referenciado como importante linguista geral: "Como comprovação prática, é especialmente relevante o testemunho do grande linguista norteamericano EDWARD SAPIR, especialista das línguas ameríndias, embora não menos teorista geral (CÂMARA JR., 1939, p. 185)". Além do Language (1921), Mattoso traduziu um conjunto de artigos, selecionados por ele, a que atribuiu o título de Linguística como ciência (1961). Este novo trabalho de tradução teve por intuito, nas palavras do próprio Mattoso, apresentar, de modo amplo e atualizado, os desdobramentos das reflexões apresentadas no trabalho anterior. Para Mattoso (1961, p. 07):

\begin{abstract}
O pensamento linguístico de Edward Sapir não está todo e definitivamente fixado no seu clássico livro Language, an introduction to the study of speech, que é de 1921. Até sua morte em 1939, o grande mestre continuou a meditar e debater os problemas da linguagem em incessantes artigos (...). Desde que publiquei a tradução portuguesa do livro Language (...) tive a ideia de completar esse empreendimento com uma tradução de artigos selecionados do mestre norte-americano, a fim de fornecer ao público brasileiro uma informação mais plena sobre a maneira por que Sapir encara o fenômeno da linguagem e sobre as suas contribuições à linguística de nossos dias.
\end{abstract}

Desde então, estas têm sido as versões da obra de Sapir elencadas nas bibliografias de obras linguísticas brasileiras, ainda que o esforço de Mattoso não tenha encontrado eco nos espaços linguísticos institucionalizados, pois o paradigma norteador da linguística brasileira na época de sua consolidação passava ao largo daquele preconizado por Sapir, e pelo próprio Mattoso em sua visão de linguista geral. Para Mattoso (in SAPIR, 2013, p. 189) Sapir, como Saussure, faz da LíNGUA o objeto da linguística, atribuindo a esta a depreensão e a análise do PADRÃO que se soto-põe e orienta a atividade da fala; igualmente, para ele, Sapir foi quem mais clara e incisivamente, na linguística norte-americana, definiu a língua como forma e levou às suas naturais consequências essa interpretação, sobretudo no estudo do padrão fonético e da classificação tipológica das línguas.

O aspecto mais relevante, a nosso ver, da filosofia linguística de Sapir presente no pensamento linguístico de Mattoso é seu mentalismo:

Sapir segue o caminho psicológico e é essencialmente "mentalista". Não só não dissocia nunca a manifestação linguística do seu conteúdo mental, mas procura compreender esse conteúdo ao explicar a manifestação linguística. Nisto se 
aproxima de Humboldt, fugindo da linha de Whitney (CÂMARA JR. in SAPIR, 2013, p. 190).

A novidade do psicologismo de Sapir é, para Mattoso, o situar-se na base "inconsciente" da atividade linguística. Afirma Mattoso (in SAPIR, 2013, p. 190) que o psicologismo de Sapir é um estudo da língua em profundidade, partindo da sua compreensão como forma intuitiva e associando-a a um estudo da psicologia do inconsciente, ainda mal delineada e para a qual a forma linguística é até um dado essencial e esclarecedor. Este caráter intuitivo da filosofia linguística de Sapir precisaria, a nosso ver, ser reavaliado não sob a perspectiva da psicologia do inconsciente, mas sob a perspectiva de uma teoria do conhecimento que considerasse a INTUIÇÃO como um ato intelectivo fundamental. Voltando-nos para a repercussão deste mentalismo no pensamento linguístico de Mattoso, podemos compreender uma afirmação tão categórica como aquela presente na Advertência para a $2^{a}$ Edição, de seu Dicionário de Filologia e Gramática: "O novo título, que é uma mudança de detalhe, vale como símbolo dessa remodelação, procurando acentuar o caráter da obra e evitar o que no título antigo poderia sugerir profissão de fé no empirismo, que rejeito e sempre rejeitei (...) (CÂMARA JR., 1970, p. 34)". O título anterior a que alude é Dicionário de fatos gramaticais; a sugestão empirista que aí se encontra no termo "fatos" desfaz-se ao depararmo-nos com a concepção de que fatos da língua, são os "fatos que podemos chamar concretos, ou antes, de preferência a fatos, as formas da língua (CÂMARA JR., 1970, p. 37)" o que se coaduna com a concepção de língua como forma defendida por Sapir.

A atividade mental é um dos fundamentos da ideia de linguagem mesma para Mattoso, de modo que para "haver linguagem, é preciso [...] uma atividade mental tanto no ponto de partida quanto no ponto de chegada. Noutros termos, é preciso que o manifestante tenha tido a intenção de manifestar-se (CÂMARA JR., 1974, p. 15)". E aqui já reencontramos nosso objeto de pesquisa, pois é no contexto da relação entre este ponto de partida e este ponto de chegada que Mattoso situa sua teorização sobre o que entende por unidade da comunicação linguística, a saber, a FRASE. 


\subsection{O programa linguístico de Mattoso Câmara Jr.: língua e estilo}

Rodrigues (2005, 24), ao analisar a obra científica de Mattoso, afirma que a importante influência que exerceu sobre os estudos da linguagem no Brasil foi exercida essencialmente através dos livros e artigos. Hampejs (1961, p. 224) já apontava a vasta produção científica de Mattoso que publicava à época (década de 1960) sobre linguística, língua portuguesa, língua inglesa e língua francesa; acentuava também a produtividade de Mattoso quanto a artigos sobre temas linguísticos que publicava em numerosas revistas nacionais e estrangeiras, tais como, Revista de Cultura, Revista Brasileira de Filologia, Boletim de Filologia, Jornal de Filologia, Letras, Verbum, Revista do Livro, Revista de Filologia Hispânica (Buenos Aires-New York), Word (New York), Romanisches Jarbuch (Hamburgo), Revista de Antropologia. Ainda a melhor análise bibliográfica, a nosso ver, da produção mattosiana encontra-se em Naro \& Reighard (1976), restando apenas ser atualizada com o acréscimo dos estudos de que tem sido objeto nos últimos anos.

O programa linguístico de Mattoso encontra-se delineado no capítulo de abertura do clássico e pioneiro Princípios de Linguística Geral (1941, 1ª ed.); encontramos nova reflexão acerca dele no Introdução às Línguas Indígenas Brasileiras (1965). Tais obras são fruto de cursos dados por Mattoso. O primeiro deles na área de linguística geral e o último destinado aos estudantes de etnologia do Museu Nacional.

O próprio Mattoso, nos fornece a síntese do programa de investigação que tal projeto enseja:

Em resumo, cada ato de linguagem, ou DISCURSO, se fundamenta num sistema de REPRESENTAÇÃO linguística, que é a LÍNGUA, e também sistematiza os recursos linguísticos representativos para a MANIFESTAÇÃO PSÍQUICA e o APELO numa estruturação estética, que é o ESTILO. A língua é, primariamente, coletiva; mas pode ter secundariamente peculiaridades individuais, constituindo o IDIOLETO. O estilo parte primariamente de um impulso pessoal; mas há todo um conjunto de coincidências estilísticas na comunidade linguística, constituindo-se o estilo coletivo (CÂMARA JR., 1974, p. 28).

Apresenta em seguida um esquema gráfico para ilustrá-lo: 


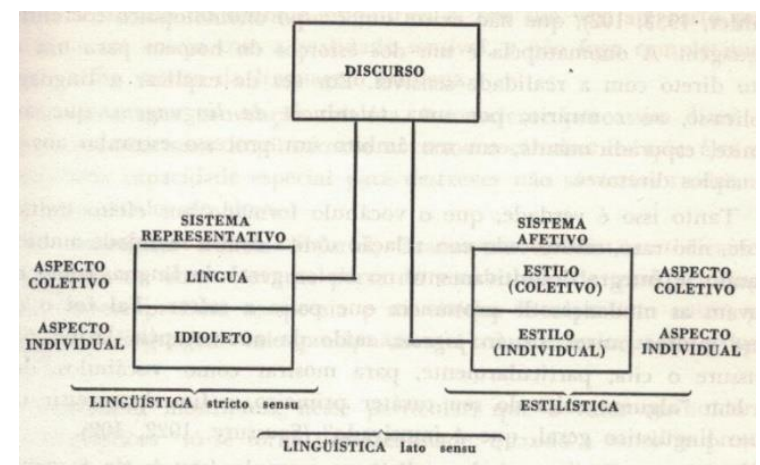

Figura 4 Esquema da linguística lato sensu em Mattoso (1974, $p$. 29).

Como podemos observar é do discurso que Mattoso parte para definir o campo de atuação da Linguística. Em sua concepção, tal campo divide-se em duas áreas: a Linguística stricto senso, que tem por objeto a Língua, e a Estilística, que tem por objeto o estilo.

Cada um dos termos aí implicados reveste conceitos matizados pelas concepções pessoais de Mattoso, consubstanciadas pelo que podemos chamar de esboço de programa de investigação. A despeito da intenção expressa de Mattoso de escrever um 'compêndio', “um resumo de doutrinas que divulgasse e reverberasse as ideias linguísticas que vigoravam nos grandes centros acadêmicos europeus e norteamericanos de sua época (CABRAL, 2004, p. 116)" _ é perfeitamente concebível que um estudioso e pesquisador com as capacidades intelectuais que Mattoso possuía não se restringisse ao papel de mero compilador, mas se colocasse como articulador, a partir de ideias e insights próprios, dos dados selecionados de modo a expressar o que pessoalmente entendia, no caso em questão, por linguagem e por seu estudo.

Diferente dos Princípios, em que há uma discussão mais geral sobre a Linguagem, na Introdução às Línguas Indígenas o interesse recaí sobre o conceito de Língua; antes de discuti-lo, no entanto, apresenta o contexto de sua emergência:

A língua aparece na comunicação por meio da fala. Os homens falam uns com os outros, e por meio desses sons vocais transmitem ideias, impressões, sentimentos. // [...] é preciso atentar que essa comunicação pela fala é muito heterogênea. Ela se realiza num ambiente determinado, em meio de uma situação definida, concreta, diante de dados indivíduos, e a situação assim estabelecida colabora na comunicação. [...] há outros processos expressivos [...] (CÂMARA JR., 1965, p. 12) 
Observamos aqui uma diferença na escolha terminológica, conceitual e de ponto de vista; no entanto, não observamos qualquer ruptura com a abordagem anterior; pelo contrário, há certo processo de precisão teórico-argumentativa advindo de um maior tempo de experiência, reflexão e estudo. A ênfase anterior no discurso recai aqui na fala como meio de comunicação que é de onde emerge a língua. Há também um realce do papel dos elementos extralinguísticos na comunicação: "primeiro, a situação concreta em que o indivíduo se acha; depois, a mímica toda, toda uma linguagem de gestos (inclusive os fisionômicos), com que se acompanha a enunciação (CÂMARA JR. 1965, p. 13)". No entanto, Mattoso acrescenta, nada disto é língua, mas tudo isto é importante, em alguma medida, porque reveste a língua com um contexto de realidade necessária à compreensão da linguagem como capacidade humana. Assim, para chegarmos à língua,

para estabelecermos o conceito de língua, temos que fazer dois desbastes preliminares: em primeiro lugar, isolar da comunicação linguística todos os elementos extralinguísticos que normalmente, muito frequentemente, pelo menos, entram nessa comunicação; e, em segundo lugar, dentro da própria comunicação linguística, isolar tudo aquilo que não é especialmente comunicativo, do ponto de vista da língua rigorosamente dita. [...] // A língua assim considerada, com essa série de desbastes, se apresenta como um sistema, como uma estrutura (CÂMARA JR. 1965, pp. 14-15).

É sempre a partir da discussão da “divisão trifuncional de Bühler” que Mattoso introduz a perspectiva estilística do fenômeno linguístico; para ele, é esta divisão que "nos dá muito melhor fundamento para a ampliação do campo da linguística (CÂMARA JR., 1978, p. 12). A função chave em sua concepção é a função representativa, pois é ela que "caracteriza essencialmente a língua" (CÂMARA JR., 1965, p. 22). No curso sobre as Línguas Indígenas, vemos uma ênfase maior neste aspecto da função representativa de modo a colocar no centro da discussão a língua como uma estrutura autônoma, passível de ser estuda por si mesma. Vejamos:

Para depreendermos a língua, entendida como representação pura, como uma configuração formal estabelecida num quadro exclusivamente representativo, temos que fazer abstração da manifestação psíquica e do apelo contidos na comunicação linguística. Essa manifestação psíquica ou esse apelo vão criar, fora da gramática, que é o estudo da representação formal, um conjunto de fenômenos a que se chama estilo, entrosados com a gramática em regra nas comunicações, mas que é preciso pôr de lado quando se faz o estudo gramatical dessas comunicações (CÂMARA JR., 1965, p. 22). 
Esta visão contrasta com o vislumbre de uma linguística do discurso, cujos fundamentos e aspectos mais significativos foram apresentados na Contribuição à estilística portuguesa; nesta, a vinculação do estilo aos elementos formais da linguagem está na base do método estilístico apresentado: "Consiste em assinalar, ao lado de um sistema de fundo intelectivo, um sistema de expressividade que nele se insinua e com ele funciona inelutavelmente (CÂMARA JR., 1978, p. 24).” Nisto consiste, parece-nos, a síntese do pensamento teórico do Mattoso linguista geral, também abrangendo aí o programa de trabalho de uma ciência linguística interessada no fenômeno linguístico integral.

\subsection{Configuração do Horizonte de Retrospecção (HR), quanto à frase, de Mattoso}

\section{Câmara}

Para Colombat et al. (2017, p. 18) o papel do historiador das ciências da linguagem é o de criar as condições de uma reflexão informada sobre a epistemologia das ciências da linguagem. Apontam, igualmente, que o historiador produz a informação sobre o sistema científico constituído por tais ciências e permite então alargar, para os linguistas, o que se pode chamar seu próprio "horizonte de retrospecção", ou seja, a memória dos resultados, os problemas, os conceitos desenvolvidos antes deles.

No contexto da tradição brasileira, estas tarefas adquirem maior relevância, seja por ser uma tradição nova, seja por caracterizar-se como uma tradição de "recepção". Traçar os horizontes de retrospecção que configuram nossa tradição de estudos da linguagem, parece-nos uma das tarefas urgentes à qual a disciplina da História das Ideias Linguísticas deve dedicar-se. Nesta perspectiva, apresentamos a configuração do HR, no que respeita à questão da frase, de um dos maiores linguistas brasileiros, Mattoso Câmara, a fim de, em parte, trazer à consciência da disciplina linguística as fecundas reflexões propostas por tão eminente estudioso. 


\subsubsection{Mattoso Câmara e a linguística nova (sincrônica, descritiva ou estática)}

Cavaliere (2014, p. 142) traça um perfil acadêmico de Mattoso Câmara, bastante curioso, na medida em que realça em sua figura os traços que o assemelham ao perfil dos antigos filólogos brasileiros. Afirma o historiador que, a seu juízo, Mattoso tem muito do perfil acadêmico que caracterizou os antigos filólogos das bases historiográficas brasileiras. Primeiro, não era incondicionalmente vinculado a um dado modelo de investigação, não obstante seja clara a predominância do estruturalismo em sua obra. Por outro lado, o próprio interesse pela língua literária também é um elemento que aproxima a obra de Mattoso das nossas bases filológicas. Não lhe resta dúvida, no entanto, de que o nome de Mattoso Câmara ficará indelevelmente inscrito na História da Linguística.

Seu nome estará inscrito como o do pioneiro no estudo estrutural da linguagem entre nós. Este pioneirismo evidencia-se não apenas nas propostas de trabalho que implementou, mas também na base bibliográfica sobre a qual assentou suas reflexões e pesquisas. Já nas Lições (1938-9) contrastava a linguística antiga de fundo históricocomparativo com uma linguística nova, sincrônica e estrutural. Sua retórica neste momento é de exaltação das novidades teórico-metodológicas e seus esforços são no sentido de absorver o novo aparato epistemológico associado, sobretudo, ao nome de Ferdinand de Saussure.

A despeito de toda a significação histórica de Saussaure, Mattoso ao longo de seu trabalho, recorre pouco às suas soluções, dedicando-se mais às propostas teóricas de seus continuadores. Não que tivesse qualquer restrição à sua doutrina, reconheceu sempre à Saussure o mérito de esclarecer, por meio de seus conceitos e dicotomias, a ordenação do campo de estudos linguísticos. O modelo de linguística geral que mais o atraia, no entanto, era aquele elaborado por Edward Sapir, na linha da filosofia linguística do mestre alemão Humboldt ${ }^{56}$. Esta preferência advém da visão ampla que

\footnotetext{
${ }^{56}$ No texto "Wilhelm von Humboldt et Edward Sapir" que preparou para o X Congresso Internacional de Linguística, realizado em Bucareste em 1967 (Texto datilografado integrante do Acervo Mattoso Câmara da Biblioteca da Universidade Católica de Petrópolis), Mattoso pontua: "Le structuralisme européen, créé par Saussure, n'a pas mis à profit l'oeuvre de Humboldt. Ses origines sont ailleurs, et à un tel point que Vossler a cru pouvoir se prévaloir de Humboldt pour combattre l'antinomie "langue-parole" de Saussure. / Au contraire, Il me semble pouvoir affirmer que Humboldt et son concept de la forme linguistique ont une place dans le structuralisme nord-américain d'Edward Sapir (1884-1939) ".
} 
Mattoso tinha do fenômeno linguístico, consubstanciada em sua constante referência ao esquema trifuncional de Bühler. Para Mattoso (2004, p. 300)

Saussure só tivera em vista, em verdade, aquilo que Bühler chama Darstellung ou seja, a representação intelectiva, a função da linguagem como meio de cristalização e organização conceptual do meio ambiente bio-físico, para fim de comunicação. Nisso era cartesiano, de acordo com as diretrizes gerais da filosofia francesa antes de Bergson. Não será temerário (creio eu) dizer que seu discípulo Bally foi justamente influenciado pelo pensamento de Bergson e assim apreendeu o que faltava à lingüística em termos saussurianos puros.

Na concepção de Mattoso o que faltava à linguística saussuriana era a atenção à "atividade linguística proveniente do apelo à simpatia humana e da exteriorização da nossa maneira de sentir a vida (ibid.)", ou seja, a inclusão aí das outras duas funções da linguagem de Bühler, Appell e Kundgabe $e^{57}$. A conformação deste complexo teórico é o que constitui a linguística latu sensu para Mattoso, como vimos na Figura 4, organizada em dois segmentos, uma linguística stricto sensu para lidar com o sistema representativo e uma estilística para lidar com o sistema afetivo, depreendido da manifestação das funções obliteradas por Saussure.

Quanto às filiações filosóficas apontadas na citação acima, não deixa de ser interessante notarmos que Mattoso não aderiu nem ao cartesianismo de Saussure nem ao bergsonismo de Bühler; a nosso ver, pendeu em muitos momentos à fenomenologia de Cassirer, mais afeita à compreensão de que a língua é,

antes de tudo, no seu esquema, uma representação do universo cultural em que o homem se acha e, como representa esse universo, as suas manifestações criam a comunicação entre os homens que vivem num mesmo ambiente cultural. / Mas a representação do universo cultural, na língua, se faz por meio de uma configuração formal. A língua é, antes de tudo forma. É a configuração formal da língua que integra os elementos culturais em grupos associativos e multiplica a aplicação de cada elemento (CÂMARA JR., 1965, p.16).

O que remete ao estruturalismo de Sapir e sua concepção da forma linguística, ou seja, um padrão (ing. pattern), que, tal como em Humboldt, é visto como uma

\footnotetext{
$57 \mathrm{Na}$ leitura que Mattoso faz da teoria funcional de Bühler temos que Dartellung corresponde à representação, Appell ao apelo à simpatia de outrem e Kundgabe à manifestação psíquica (CÂMARA JR., 2004, p. 300).
} 
estrutura mental; forma esta, tanto fônica como conceitual. Chegamos assim ao critério básico que norteia as reflexões linguísticas mattosianas, a saber, a de que "para haver linguagem, é preciso [...] uma atividade mental tanto no ponto de partida quanto no ponto de chegada (CÂMARA JR., 1974, p. 15)”.

É nesta perspectiva que podemos compreender a importância dada por Mattoso à distinção feita por Saussure entre langue e parole, distinção esta que também enseja a emergência da questão da frase no pensamento mattosiano, como veremos ainda neste capítulo. Já na Lição II (1939, p. 184) de seu primeiro curso de Linguística Geral aparece referenciada esta distinção:

De um lado, ha o acervo tradicional, o material aceito e utilizado por todos, o qual constitui a LíNGUA, propriamente dita; de outro lado, há a contribuição pessoal do sujeito falante, que se manifesta no uso que ele faz da língua: donde considerar SAUSSURE, a parte desta última, la parole (que podemos traduzir por DISCURSO, já que o próprio Saussure coteja o têrmo francês com o latim sermo).

É no âmbito desta distinção que surge o problema da unidade linguística própria à fala e, consequentemente a questão da frase, pois, ainda seguindo a forma com que aparece esta discussão na Lição II (id.), na frase,

combinam-se a contribuição coletiva e a individual, ao passo que o vocábulo é evidentemente um elemento da LíNGUA, como são a sílaba e o fonema. Nestas condições, não é possível propor, em vez da unidade-vocábulo, uma unidade-frase, porque a frase, parte do discurso, tem estrutura compósita e não é exclusivamente, como cumpriria para tal fim, fato puro da LínGUA. Daí, a múltipla diversidade sob que se apresenta, e a circunstância de que o ponto de contato principal entre variadas frases é, muitas vezes, a presença de um ou mais vocábulos comuns.

Como vemos, a questão da frase, surge neste primeiro momento marcada, de modo restritivo, pela visão sistêmica da língua em Saussure. Este aspecto do pensamento mattosiano evoluirá de modo significativo, sem, no entanto, abandonar as bases aí já bem assentadas.

Mattoso Câmara seguirá a trilha do estruturalismo saussuriano apoiado não no pensamento original do mestre genebrino, mas no de seus discípulos que se dividem, na concepção de nosso linguista, em dois grupos: o primeiro é composto por aqueles que 
tentaram discutir e aclarar as ideias essências da doutrina, tais como, Albert Secheraye, Alan Gardiner e Joseph Vendryes; o segundo, por aqueles que partiram da doutrina do mestre para investigar áreas da linguística que ele deixara intactas, são eles Antoine Meilllet e Charles Bally (CÂMARA JR., 1986).

Do primeiro grupo, Mattoso se apropriou da distinção entre discurso e língua, aprofunda por Secheraye e por Gardiner; bem como, do primeiro destes, da discussão da frase ligada ao problema genético da linguagem e na distinção entre frase da língua e frase do discurso; do segundo destes apropriou-se de uma teoria total da frase, vista como a miniatura de um drama em quatro constituintes (o falante, o ouvinte, a situação e a coisa significada). Do segundo grupo, aproximou-se do novo campo de pesquisa linguística nomeado estilística por Bally.

\subsubsection{Mattoso Câmara e a teoria da frase}

Como vimos a questão da frase foi cedo objeto de reflexão por parte de Mattoso Câmara; as respostas que ofereceu a ela foram aperfeiçoadas ao longo dos anos e da experiência. Deste processo de refinamento das respostas à questão da frase é que podemos depreender a constituição e estrutura do horizonte de retrospecção, bem como compreender a forma como o domínio de objetos de que nos servimos, constituído sobretudo pela obra publicada por Mattoso Câmara, é afetado pela temporalidade, resultando naquilo que Auroux (2006) chamou de modo de historicização.

Os primórdios da teoria da frase no trabalho linguístico de Mattoso encontram-se nas Lições de linguística geral, ministradas no curso da UDF e publicadas na Revista de Cultura (1939; 1940); encontramos nelas a primeira formulação, elaborada por Mattoso, da questão da frase sob o ponto de vista da linguística geral. Na Lição I encontra-se:

A sílaba é a unidade espontânea na cadeia dos sons chamada frase, como evidencia aliás a métrica silábica entre povos primitivos (riques indianos, lírica helênica de Lesbos), quer a escrita silábica, que é a primeira a surgir, quando uma língua por si mesma, se inicia na grafia fonética, procurando representar visualmente os sons e não as idéias contidas na frase. / São estes os dois elementos fonéticos fundamentais: sílaba, unidade, e frase, série variável de sílabas. Mas, da mesma sorte que a sílaba admite naturalmente a sub-divisão em fonemas (consoantes e vogais), a frase, ou 
cadeia de sons, de certa extensão, abrange grupos de sílabas, que são os vocábulos fonéticos (Grifos nossos, CÂMARA JR., 1939, LLG I, pp. 101-2)

Ao lado desta concepção de frase como "cadeia de sons" encontramos na Lição IX outra que a toma por "unidade do discurso":

Partindo da distinção fundamental entre língua e discurso, é-nos fácil definir frase, dizendo, com Gardiner, que é ela a unidade do discurso, e resulta da aplicação dos elementos da língua para a manifestação, pela linguagem, de estados psíquicos individuais. Evita-se assim toda confusão entre frase e vocábulo, com assentar-se a diferença, entre uma e outro, não na extensão da enunciação ou no conteúdo significativo, senão exclusivamente, nos planos linguísticos distintos, em que respectivamente se manifestam. É assim que um vocábulo Pedro passa a ser uma frase na exclamação - Pedro!, com que chamamos um indivíduo dêsse nome (CÂMARA JR., 1940, p. 83).

Estas definições refletem o aspecto dual básico, não só do signo linguístico, mas da linguagem mesma, ou seja, suas necessárias materialidade e expressividade, ou em outros termos, som e ideia. Aspectos ligados à dicotomia saussuriana langue e parole, que nas Lições vão resultar nos "construtos teóricos" FONAÇÃO e FALA. Para França (1998, p. 171) o termo FONAÇÃo foi usado, em 1939, em dois sentidos diferentes, não explícitos no texto de Mattoso. No primeiro sentido significaria o ato de emitir sons ou os sons articulados abstraídos do seu conteúdo (significado) e no segundo seria sinônimo da parole saussuriana, separando assim, implicitamente, dois aspectos/planos do fenômeno em observação na explicação mattosiana em 1939. Explicitamente Mattoso (1939, p. 101) afirma:

Cabe agora considerar a linguagem na atividade da fala, que é a enunciação dos sons vocálicos considerada no intento com que a fazemos e na significação que lhes é emprestada. Em confronto com ela, a fonação ou enunciação dos sons vocálicos considerados em si mesmos, nos movimentos articulatórios que os determinam e nos consequentes efeitos acústicos, é uma abstração, á maneira do número aritmético (5, 12, etc.) em cotejo com um número correspondente de objetos precisos (5 livros, 12 casas, etc.)

O interesse de tais "construtos teóricos" revela-se nos elementos que a partir deles são configurados: vocábulo fonético e vocábulo significativo. Mattoso (1939, p.101) considerou esta distinção "um dos mais intrincados problemas da linguística". 
No entanto, o que nos interessa aqui é a dupla articulação da concepção de frase, como cadeia de sons e como elemento contendo ideias, e sua convergência sob o traço unidade. Os termos usados aí implicam a noção de uma forte ligação dos termos ou elementos menores para compor a frase: série de sílabas, cadeia de sons e, mesmo, unidade do discurso. A despeito da compreensão da frase, enquanto série variável de sílabas, como um dos dois elementos fonéticos fundamentais - sendo a sílaba o outro o interesse de Mattoso recaiu, quanto à FONAÇÃO, sobre a unidade vocábulo; França (2007) verificou certa ênfase em precisar o lugar e o valor exato da unidade vocábulo perpassando todo o conjunto de textos das Lições. A questão da definição da palavra e seu uso, juntamente com a determinação das unidades e dos seus respectivos planos “como distinguir a frase do vocábulo?" (1940 LLG IX, p. 83) - parece ter sido uma dificuldade relevante na época. A frase, ele estudou-a no contexto não da fala, mas do discurso.

A distinção destas unidades, vocábulo e frase, ensejou igualmente a distinção entre morfologia e sintaxe; a partir da discussão da pertinência daquela como parte da gramática e da análise da sintagmática saussuriana, Mattoso (1975 [1955], p. 14) conclui que a sintaxe não coincide com a sintagmática, sendo aquela a parte da gramática que estuda as sequências frasais, isto é, aquelas em que um valor linguístico associativo não interfere e não entra em conflito com o valor sintagmático que a sucessão de formas determina. Por valor linguístico associativo, Mattoso, sempre a partir de Saussure, entende a circunstância de que associamos, imanente e permanentemente, determinada forma linguística com outras formas do sistema linguístico; por valor sintagmático, no sentido amplo que possui no Curso de linguística geral (1916) de Saussure, entende o fato de os elementos linguísticos adquirirem um valor novo pela circunstância de se acharem em sequência, o que ocorre com palavras compostas, derivadas, membros de frases e frases inteiras - a todos estes elementos atribui-se, em Saussure, a noção de sintagma.

A proposta de uma sintagmática ampla poderia levar ao esvaimento, nos termos de Mattoso (ibid., p. 13), de "uma sintaxe stricto-sensu, como estudo das frases em que essas formas se integram". Mattoso (ibid.) rejeita tal possibilidade apoiado na diferença básica e claramente apreensível entre o sintagma que é palavra composta e o sintagmafrase: naquele o valor sintagmático se cristaliza num novo valor morfológico, neste a significação global da sequência existe apenas linearmente na enunciação em que 
figura. Estas conclusões derivam, a nosso ver, de certo entendimento da frase como sendo uma "unidade transitória e instantânea, que se cria com as circunstâncias do momento (CÂMARA JR, LLG IX, p. 83)"'.

Como criações linguísticas individuais, as frases são, pois, do âmbito do discurso, entendido como "a atividade linguística nas múltiplas e infindáveis ocorrências da vida cotidiana" (CÂMARA JR., 1974, p. 24). É, a partir deste contexto, que Mattoso apresenta e discute a afirmação de que a frase é a unidade do discurso, auferida em Gardiner (1932). Afirmação esta que considerou uma solução simplista, opinião corroborada à luz da teoria sintagmática de Mikus: "O autor desta Crônica não pode senão concordar com um ponto de vista, já por ele externado ao repelir a solução simplista de Gardiner, que vê na frase a ‘unidade do discurso' (CÂMARA JR., 1975, p. 20)". Na mesma Crônica nos remete ao Princípios de linguística geral (2 $2^{\mathrm{a}}$ ed.) onde melhor apresenta sua posição:

\begin{abstract}
A definição que propusemos no parágrafo anterior, de acordo com Gardiner, não é, apesar de tudo, plenamente satisfatória. // A frase também pertence ao âmbito da LÍNGUA por duas circunstâncias. // Em primeiro lugar, porque se formula com aqueles elementos fixos, que são os fonemas e as sílabas do sistema fônico vigente, bem como os morfemas, semantemas e vocábulos reconhecidos na língua. // Em segundo lugar, porque se pauta por determinados MODELOS FORMAIS, impostos pela língua aos indivíduos (PLG 2a ed., p. 158).
\end{abstract}

Estes "modelos formais" foram chamados FRASES DA LÍNGUA por Albert Sechehaye, discípulo de Saussure, em contraste com as FRASES DO DISCURSO, entendidas como enunciações concretas, de onde aquelas são deduzidas, por abstração. O processo, portanto, de dedução das frases da língua a partir das frases do discurso é tarefa da análise linguística. Mattoso (1974, p. 165) avança nesta ordem de teorização ao propor que a "frase da língua é uma unidade de comunicação, que em princípio é bastante para esse fim”. É ela resultado da abstração feita da situação e dos recursos extralinguísticos, ou seja, de todo o contexto discursivo, de modo que os elementos linguísticos, funcionando de per si, são suficientes para uma comunicação clara, precisa e bem definida. De acordo com Mattoso, este construto é aquilo que tradicionalmente tem se chamado ORAÇÃO ou PROPOSIÇÃO. O que interessa, sobremaneira, à Mattoso é a maneira como ocorre esta constituição: 
Fá-lo, conforme a língua, por uma pauta peculiar, dependente das categorias gramaticais e dos morfemas de que a língua dispõe. Criam-se assim PADRÕES ESTRUTURAIS, de tal sorte divergentes que uma comunicação de ideias, simples e comuns a qualquer povo, adquire, em cada língua, uma forma exótica e extravagante para a apreensão por indivíduo de outra língua (CÂMARA JR., p. 166).

Não nos esqueçamos que a teoria de que ora traçamos as linhas principais foi pensada a partir do campo de estudos da linguística geral, à qual "cabe aí focalizar apenas o material lingüístico, isto é, as formas mínimas, fônicamente construídas com os fonemas, os prosodemas e as sílabas da língua, que se articulam na enunciação frasal (ibid., p. 165); nesta perspectiva, a ideia de padrões estruturais surge como um importante instrumento de estudo linguístico, na medida em que é da "análise dos padrões frasais que trata a parte da gramática tradicionalmente chamada sintaxe". Como, no entanto, caracterizar um padrão frasal, Mattoso Câmara (ibid., pp. 166-7) resume em 3 itens seus traços característicos: 1) a ordem dos vocábulos; 2) a associação dos vocábulos, de acordo com a sua categoria; e 3) a concordância de categorias entre os vocábulos, de acordo com um princípio dado.

Até aqui temos visto a co-presença dos conhecimentos advindos da corrente linguista inaugurada por Ferdinand de Saussure, sobretudo nas figuras emblemáticas de seus mais próximos continuadores Albert Sechehaye e Alan Gardiner, que como visto, aprofundaram a compreensão da dicotomia langue-parole. Esta perspectiva predominou na exposição mattosiana até a $1^{\mathrm{a}}$ edição dos Princípios de linguística geral (1942). A partir da $2^{\text {a }}$ edição da mesma obra (1954) novas referências bibliográficas são incorporadas ao Horizonte de Retrospecção a partir do qual Mattoso Câmara tratou a questão da frase. Ao chegar na $4^{\mathrm{a}}$ edição, a última revista pelo autor, o Princípios apresenta o seguinte elenco de referências em seu capítulo XI sobre a conceituação da frase; destacamos os autores vinculados ao Círculo Linguístico de Praga:

\begin{tabular}{|c|c|c|}
\hline AUTOR & PÁGINA ${ }^{58}$ E TEMA & $\begin{array}{c}\text { FILIAÇÃO AO CÍRCULO } \\
\text { LINGUÍSTICO DE PRAGA } \\
\text { (CLP) }\end{array}$ \\
\hline Saussure (1922) & p. 162 conceito de discurso & \\
\hline
\end{tabular}

${ }^{58}$ Página referente à sétima impressão da $4^{\mathrm{a}}$ edição dos Princípios publicada pela Livraria Acadêmica em 1974. 


\begin{tabular}{|c|c|c|}
\hline & $\begin{array}{l}\text { p.165 tipos gerais }=\text { frases da } \\
\text { língua, tipos frasais }\end{array}$ & \\
\hline Gardiner (1932) & $\begin{array}{l}\text { p. } 162 \text { frase como unidade do } \\
\text { discurso / "pequeno drama" } \\
\text { p. } 164 \text { (Dionísio da Trácia\} } \\
\text { autoteles) / propósito definido- } \\
\text { unidade frasal-intenção do } \\
\text { falante / } \\
\text { p. } 170 \text { exemplo: uma frase única } \\
\text { com aposição, pura e simples, } \\
\text { de duas orações }\end{array}$ & \\
\hline Bühler $(1933 ; 1934)$ & $\begin{array}{l}\text { p. } 162 \text { / nota } 1 \text { funções da } \\
\text { linguagem relação com os tipos } \\
\text { de frases (também Gardiner) / } \\
\text { p. } 171 \text { atividade linguística / } \\
\text { esquema de Bühler }\end{array}$ & CLP \\
\hline Regula (1951) & $\begin{array}{l}\text { p. } 162 \text { / nota } 1 \\
\text { emoção/tonalidade (Mattoso } \\
\text { essência do estilo) }\end{array}$ & \\
\hline Trnka (1949) & $\begin{array}{l}\text { p. } 163 \text { três planos hierárquicos } \\
\text { na linguagem (fonemas, } \\
\text { vocábulos, frases) }\end{array}$ & CLP \\
\hline Karcevki (1931) & $\begin{array}{l}\text { p. } 163 \text { entoação ou tom frasal / } \\
\text { p. } 166 \text { oração ou proposição } \\
\text { (abstração feita da situação em } \\
\text { que se acha o falante, e dos } \\
\text { recursos extralinguísticos de } \\
\text { que ele se serve, os elementos } \\
\text { linguísticos funcionando de per } \\
\text { si, são suficientes para } \\
\text { estabelecer uma comunicação } \\
\text { clara, precisa e bem definida...) }\end{array}$ & CLP \\
\hline Groot (1949) & p.163 entoação & CLP \\
\hline Pos (1931) & $\begin{array}{l}\text { p.163/nota } 2 \text { equívoco (não } \\
\text { considera a entoação) }\end{array}$ & \\
\hline Sechehaye (1933) & $\begin{array}{l}\text { p. } 165 \text { tradução por } \\
\text { equivalência do conjunto }\end{array}$ & \\
\hline Bally (1950) & $\begin{array}{l}\text { p. } 165 / \text { nota } 1 \text { elementos } \\
\text { concretos como complemento }\end{array}$ & \\
\hline
\end{tabular}




\begin{tabular}{|c|c|c|}
\hline Brunot (1937) & $\begin{array}{l}\text { p. } 165 / \mathrm{n} .1 \text { frase de indicação / } \\
\text { título de casa comercial }\end{array}$ & \\
\hline Henry (1935) & $\begin{array}{l}\text { p. } 166 \text { exemplo fábula em } \\
\text { kaingang }\end{array}$ & \\
\hline Vendryes (1921) & $\begin{array}{l}\text { p.168 técnica própria para o } \\
\text { discurso escrito / a língua } \\
\text { escrita é um conjunto } \\
\text { normalizado e generalizado / } \\
\text { (1948) } \\
\text { p.169/nota } 2 \text { relação dos } \\
\text { infinitivos com nomes verbais }\end{array}$ & \\
\hline Herskovits (1960) & $\begin{array}{l}\text { p.168/nota } 2 \text { antropólogo / } \\
\text { escrita como critério de } \\
\text { classificação dos povos em } \\
\text { primitivos e civilizados }\end{array}$ & \\
\hline Vachek (1939) & $\begin{array}{l}\text { p.168/nota } 2 \text { linguística procura } \\
\text { focalizar a escrita de per si }\end{array}$ & CLP \\
\hline Meillet (1948) & $\begin{array}{l}\text { p.169/nota } 2 \text { relação dos } \\
\text { infinitivos com nomes verbais }\end{array}$ & \\
\hline Whitney (1948) & $\begin{array}{l}\text { p. } 170 \text { ausência das conjunções } \\
\text { subordinativas no sânscrito }\end{array}$ & \\
\hline Pei (1946) & $\begin{array}{l}\text { p. } 170 \text { uma frase única com } \\
\text { aposição, pura e simples, de } \\
\text { duas orações: tipos frasais } \\
\text { árabes }\end{array}$ & \\
\hline Marouzeau (1925) & $\begin{array}{l}\text { p. } 170 \text { (BUFFON) “o estilo é o } \\
\text { homem” / } \\
\text { p. } 171 \text { (LEO SPITZER) estado } \\
\text { psíquico integral, mais ou } \\
\text { menos forte, mais ou menos } \\
\text { explícito }\end{array}$ & \\
\hline Vossler $(1929 ; 1932 ; 1943)$ & $\begin{array}{l}\text { p. } 170 \text { escola idealista / estudo } \\
\text { do estilo como contribuição } \\
\text { individual na formulação da } \\
\text { frase / contrapõe o elan } \\
\text { estilístico à "automatização" da } \\
\text { norma coletiva (Mattoso refuta } \\
\text { esta posição logo em seguida) / } \\
\text { (1922) (GOETHE) a estilística } \\
\text { pode ser um meio de penetrar }\end{array}$ & \\
\hline
\end{tabular}




\begin{tabular}{|c|c|c|}
\hline & $\begin{array}{l}\text { numa psique individual / } \\
\text { aforismo: "O que pensas } \\
\text { pertence a todos; só é } \\
\text { privativamente teu o que sente". }\end{array}$ & \\
\hline Câmara Jr. (1953) & $\begin{array}{l}\text { p. } 171 \text { além da informação, } \\
\text { chegar à expressividade }\end{array}$ & \\
\hline Mukarovski (1955) & $\begin{array}{l}\text { p.171 pautas da língua } \\
\text { essencialmente para fins da } \\
\text { representação pura e } \\
\text { comunicação informativa, } \\
\text { esteticamente indiferente / nota } \\
1 \text { / p. 171-2 frase pode } \\
\text { apresentar-se sob uma forma } \\
\text { não usual em face da norma } \\
\text { linguística coletiva e tradicional }\end{array}$ & \\
\hline Langer (1942) & $\begin{array}{l}\text { p.172/nota } 2 \text { processo de } \\
\text { formulação estilística }\end{array}$ & \\
\hline Cassirer $(1933 ; 1945 ; 1953)$ & p.173 mundo dos objetos & \\
\hline
\end{tabular}

São três os temas reformulados por Mattoso de acordo com as propostas do Círculo Linguístico de Praga: a absorvente teoria das funções da linguagem de Bühler permitiu que alargasse o escopo da linguística latu sensu; por outro lado, tanto a proposta de hierarquia dos níveis linguísticos de Trnka quanto o importante papel da entoação na conceituação da frase apontado por Karcevski levam a um processo de diferenciação segura das unidades VOCÁBULO e FRASE a partir da dinâmica dos valores semióticos proporcionada pela diferença dos níveis linguísticos: "Os elementos de um plano se dispõem no plano seguinte para constituir uma unidade lingüística mais elevada (CÂMARA JR., 1974, p. 163)".

É através deste Horizonte de Retrospecção que Mattoso Câmara chega, por fim, à síntese conceitual que se encontra no Dicionário de Filologia e Gramática (1970, p. 187):

FRASE - Unidade de comunicação linguística, caracterizada, como tal, do ponto de vista comunicativo - por ter um propósito 
definido e ser suficiente para defini-lo e do ponto de vista fonético - por uma entoação, que lhe assinala nitidamente o começo e o fim. É assim a divisão elementar do discurso, mas pertence à estrutura linguística por obedecer a padrões sintáticos vigentes na língua, no seu sentido de sistema por que se pauta o discurso.

$\mathrm{Na}$ linguagem oral da comunicação cotidiana, a frase é complementada pela mímica do falante e pelos dados da situação em que é enunciada, pois “desenvolve-se então um pequeno drama, em que um falante se dirige a pelo menos um ouvinte sobre um assunto em determinada situação concreta (Câmara, 1959, 193)", e pode consistir numa única palavra ou até numa interjeição.

Quando, ao contrário, a frase contém linguisticamente em si todos os dados para a comunicação do seu assunto, sem necessidade da mímica e da situação para completa-los, tem-se a frase integralmente linguística, em padrão de oração.

\subsubsection{A questão da análise e dos padrões da frase portuguesa}

Nosso interesse ao longo deste relato voltou-se mais para a conceituação da frase do que para a sua estruturação; não assim em Mattoso, em cujo trabalho encontramos discussões tanto conceituais quanto estruturais. Duas ordens de questões se apresentam quanto a este tema: a da linguística geral, discutida no capítulo XII dos Princípios, em

que Mattoso esmiúça a estrutura geral da frase e suas estruturas específicas tendo como suporte a diversidade tipológica das línguas de diferentes partes do mundo, e no capítulo XI da História e estrutura, no qual esforça-se por apresentar os padrões frasais da língua portuguesa; a outra ordem de questões é a referente à didática da língua portuguesa, marcada por críticas de Mattoso ao modelo de análise lógica ou sintática.

Interessa-nos, na primeira ordem de questões, ter em vista, como contribuição original de Mattoso Câmara, o seu estudo sobre os padrões frasais da língua portuguesa. 
Silva (2005, p. 40) afirma que, do seu ponto de vista, é o capítulo XI, o menos rico, embora informativo, por causa da abordagem diacrônica do livro, bem como, porque, posteriormente a Mattoso Câmara, a sintaxe da sentença tenha sido o centro da pesquisa, tanto no gerativismo como no funcionalismo; nós, por outro lado, consideramos ser este, do ponto de vista da História das Ideias Linguísticas, um marco importante para a historicização do pensamento linguístico brasileiro por sua caracterização dos padrões frásicos da língua portuguesa. Mattoso diferenciava a sintagmática da sintaxe, como vimos; no rastro desta diferenciação, entendemos que, do ponto de vista linguístico, pode-se também diferenciar o padrão frásico do construto sintático, sendo aquele a "pauta peculiar, dependente das categorias gramaticais e dos morfemas de que a língua dispõe (CÂMRA JR., 1974, p. 166)" e este o resultado do jogo, no interior do padrão frásico, com "a ordem, a associação e a concordância entre os vocábulos (ibid., p.167)”.

A segunda ordem de questões está ligada às severas críticas que Mattoso dirigiu ao modelo de análise da frase praticado até sua época. Na comunicação que apresentou no VI Colóquio Internacional Luso-Brasileiro, realizado nos Estados Unidos da América em 1966, intitulada “Os estudos de português no Brasil”, Mattoso Câmara ao dividir tais estudos em dois períodos - um passado, o filológico, outro presente, o linguístico - diz-nos que houve, no período filológico uma elaboração da teoria da frase, caracterizada como "análise lógica" ou "análise sintática", inspirada pelo gramático inglês Mason que, no julgamento de Mattoso, transpôs para o ensino gramatical as conclusões de ordem lógica de Stuart Mill e Alexander Bain. De acordo com Mattoso Câmara:

\footnotetext{
Houve muitas divergências e conflitos entre os nossos teoristas, mas sempre na linha diretriz lógica, assim estabelecida. Era em essência um approach de ordem primariamente semântica, sem maior atenção à forma lingüística. Procurava nos elementos constituintes da oração, antes de tudo, uma significação característica, deduzida de um quadro de categorias lógicas (CÂMARA JR., 1975, p. 203).
}

No período linguístico, continua Mattoso Câmara, persistiu, de maneira geral, este mesmo modelo de análise da frase com algumas poucas tentativas no sentido de alargar os quadros lógicos dentro da compreensão cabal da expressão linguística. Mattoso cita a Teoria da análise sintática (1956), de Rocha Lima, O fator psicológico 
na evolução sintática (1953), de Cândido Jucá Filho e Subconsciência e afetividade na língua portuguesa (1954), de Jesus Bello Galvão. Especial referência faz Mattoso à Madre Olívia, que trabalhava noutro sentido:

Ela submete cada constituinte da frase à exegese, do ponto de vista da função da frase na comunicação dos estados mentais. O grave problema dessa orientação, que ela não resolveu, é o estabelecimento de um quadro cabal teórico de estados mentais possíveis, que, além de insuperavelmente intrincado, escapa dos termos de uma pesquisa linguística (CÂMARA JR, 1975 [1966], p. 214).

Para Mattoso (in OLÍVIA, 1970) uma legítima teoria da frase não adviria da análise lógico-semântica, nem tampouco da abordagem mentalista do tipo pretendido por Madre Olívia, mas da análise da forma linguística, primariamente considerada. Tanto assim que considera a proposta desta estudiosa, ainda que de algum modo inovadora, como não sendo uma renovação em moldes formais, especialmente atraentes para as suas predileções estruturalistas. Em contrapartida Mattoso enumera aí os estudos com os quais estava familiarizado e mais afeitos ao seu gosto formalista - um formalismo, ressaltemos, com intuitos descritivos e de caráter sincrônico:

Jespersen - Filosofia da Gramática (1924)

Saussure - conceito de "sintagma"

Bally - Linguística geral e linguística francesa (1944)

F. Mikus - teoria sintagmática

Hans Glinz - Forma interna do Alemão (1952)

Círculo Linguístico de Praga (1929-39)

Karcevski - esboço de sintaxe funcional

Martinet - artigo em Word (janeiro, 1960) e Elementos de linguística geral (1960)

Bloomfield (1933) - teoria dos constituintes imediatos

Charles Fries (1952) 
Eugene Nida (1960)

Charles Hocket - Curso de linguística moderna (1958)

Zellig Harris - distribucionalismo

Kenneth Pike - tagmémica

N. Chomsky - gramática transformacional

Todas estas são, de acordo com Mattoso, orientações essencialmente formais, embora, adverte-nos, muitas joguem concomitantemente, como especialmente a de Bally e a de Glinz, com a análise semântica, e nenhuma abandone a rigor, a não ser a de Harris, o recurso à compreensão significativa.

Por ocasião da promulgação da Nomenclatura Gramatical Brasileira, em 1959, Mattoso proferiu na então Faculdade Católica de Petrópolis um curso para comentá-la. Nesta ocasião volta à carga em suas críticas ao modelo de análise lógica; reconhece que, “de um lado, a frase é a unidade essencial da comunicação linguística e todos os elementos de uma língua convergem, por assim dizer, para a eficiente elaboração das frases, e, de outro lado, o conhecimento de tudo que se refere à língua, tem de ser adquirido por meio da análise (CÂMARA JR., 1975 [1960], p. 63). O problema, a seu ver, é a pretensão de resumir todo o esforço de estudo da língua à análise lógica, desprezando outros temas importantes, imaginando que tal análise da frase seja um estudo que se baste a si mesmo. Em sua opinião, a didática da língua materna deveria basear-se no ensino da teoria gramatical, pois só ela que dá “a compreensão sincrônica do sistema, para possibilitar o manuseio seguro desse sistema no tipo de língua 'adquirida', que é a língua literária (id. ibid.)”. A análise sintática, fora dos moldes lógico-semânticos praticados costumeiramente, entendida como análise formal dos constituintes frasais é, para Mattoso Câmara, apenas uma parte básica desta teoria gramatical.

Algumas notas que se encontram no Acervo Mattoso Câmara ${ }^{59}$ da Universidade Católica de Petrópolis indicam que ele pretendeu uma tese sobre sintaxe portuguesa; também o elenco de autores e obras que compõem o seu horizonte de retrospecção

\footnotetext{
${ }^{59}$ Vide amostra em Anexo I.
} 
quanto à frase evidenciam certo interesse na sintaxe; a sintaxe afigura-se assim um tema latente em seu pensamento. Em Valter Kehdi (1998, 2004), encontramos o lineamento da sintaxe mattosiana, cujos contornos resume como segue:

Partindo da noção de frase como unidade do discurso, com seus quatro elementos essenciais: o falante, o ouvinte, o assunto e a situação, bem como a especial importância atribuída à manifestação psíquica e apelo, integrados à simples informação (na esteira da Sprachteorie, de Karl Bühler), Mattoso Câmara estabelece a interpretação entre as frases intelectiva e afetiva, propondo assim, uma sintaxe vinculada à estilística. Essa posição vai impedi-lo de aderir à sintaxe formalista dos bloomfieldianos, embora, como o mostraremos, não se possa deixar de reconhecer a proposta mattosiana de uma sintaxe rigorosa, elaborada e, sobretudo, explorável (KEHDI, 2004, p. 106).

Kehdi (2004) ressalta assim que a sintaxe não foi tão negligenciada por Mattoso quanto se pode pensar. Seguramente, Mattoso não pretendia seguir o caminho dos bloomfildianos, na medida em que suas convicções estavam baseadas numa filosofia linguística outra, a saber, a sapiriana, como vimos ao tratar do Mattoso linguista geral.

Em termos da prática didática, por um lado, e da linguística, por outro, encontramos na obra mattosiana as seguintes abordagens ou tentativas de aplicação dos princípios (forma e padrões frasais) que, a seu ver, melhor norteariam uma reflexão sobre a sintaxe, teoricamente elaborados nos Princípios e sintetizados, sobretudo, no Dicionário:

- Em sua Gramática aplicou o princípio formal à análise sintática que, com a análise léxica, definiu como segue:

A análise léxica consiste em considerar separadamente as palavras de uma frase, para classificá-las quanto à sua espécie e às suas flexões. / A análise sintática consiste em separar as orações de uma frase, e, em cada oração, distinguir o sujeito e o predicado, e, neste, o verbo e os complementos que integram o sentido da frase. / Pode-se fazer ao mesmo tempo a análise sintática e a léxica, considerando-se separadamente as diversas palavras do sujeito e do predicado afim de classificá-las quanto à sua espécie e suas flexões (CÂMARA JR. 1957, 150). 
- Em História e estrutura encontra-se a análise dos padrões frasais da língua portuguesa cujo levantamento encontra-se no Anexo III.

Como ficou assentado nos Princípios é da análise dos padrões frasais, resultantes da maneira por que em cada língua aí se joga com a ORDEM, a ASSOCIAÇÃO e a CONCORDÂNCIA entre os vocábulos, que trata a parte da gramática tradicionalmente chamada sintaxe, ao lado da morfologia, que depreende os morfemas gramaticais e a sua integração nas unidades fixas chamadas vocábulos (CÂMARA JR., 1974, p. 167).

Por fim, como sintetizou em aula proferida no curso de crítica textual, ministrado no Instituto Nacional do Livro, em 1966, cujas transcrições encontram-se no Acervo Mattoso Câmara:

Falamos por frases. Elas são a realidade linguística. Está intimamente ligada ao contexto e situação. A oração é um tipo especial de frase. A frase pertence à parole, mas contém em si um padrão que é da língua, além da fonologia e das palavras (CÂMARA JR., 1966) 


\section{CONSIDERAÇÕES FINAIS}

A recolha das principais emergências da ideia de frase no longo tempo foi o meio através do qual pensamos evidenciar o problema conceitual que lhe é constante. $\mathrm{O}$ longo tempo, no entanto, é um elemento difícil de ser manejado, na medida em que a cada entroncamento encontrado nele desdobram-se diante de nós redes de fatos ainda não considerados, interessantes e potencialmente importantes para a trama que pretendemos estabelecer. A despeito das dificuldades, fomos felizes no desenho que tecemos com as linhas históricas de que dispúnhamos.

Ativemo-nos à questão da conceituação da frase em momentos determinados da história do pensamento linguístico ocidental, tendo por parâmetro desta recolha os reflexos destas questões no pensamento linguístico de Mattoso Câmara. Foi este, afinal de contas, o nosso grande personagem e, também, guia em nosso percurso de busca e de compreensão da historicização da conceituação da frase. Apoiamo-nos, por conseguinte, na proposta teórica da História das Ideias Linguísticas, auferida nos trabalhos de Sylvain Auroux e na interlocução com a professora Marli Quadros Leite ${ }^{60}$, principal representante desta corrente teórica no Brasil.

Partimos da compreensão da ideia de frase como o conjunto das representações dos segmentos da cadeia dialógico-discursiva evidenciadas nos termos FRASE, ORAÇÃO, PERÍODO, SENTENÇA, PROPOSIÇÃO, ENUNCIADO e LÓGOS e a localizamos no âmbito das ciências e disciplinas dedicadas ao estudo qualificativo e especulativo da linguagem; desta forma, encontramos a ideia de frase no âmbito da filosofia, da gramática e da linguística que também nos serviram como balizas para o recorte temporal: Antiguidade Clássica, França racionalista e Brasil moderno.

Tomamos a concepção filosófica do lógos como a mais remota emergência da ideia de frase. A partir dela pudemos observar que a unidade comunicativa que é a frase já era percebida em seu caráter de fala e de unidade tensional desde Heráclito; também, em Parmênides, que nela se revelam, a partir da manifestação de uma opinião, o valor cognoscitivo da percepção, bem como a partir da manifestação da verdade, o valor do pensamento. Com Platão e Aristóteles, vimos a emergência do aspecto analítico da

\footnotetext{
${ }^{60}$ Professora Titular do Departamento de Letras Clássicas e Vernáculas, na Universidade de São Paulo.
} 
reflexão sobre a frase, o que, também, encaminhou a questão para o campo estrito das considerações linguísticas, cujo momento intermediário encontramos nas reflexões semióticas dos estoicos que incluem entre o som e o objeto, o dizível (lektón) e que culmina na conceituação dos alexandrinos da frase como "um agrupamento ordenado de palavras em prosa que manifesta um pensamento completo".

A discussão da gramática como arte/disciplina, como ciência e como instrumento linguístico permitiu-nos evidenciar a gramática como o lugar onde as discussões sobre a questão da frase e sua conceituação implicaram problemas de ordem teórica e metodológica. Assim, a Téchne Grammatikè ilustra os esforços de elaboração metalinguística da ideia de frase no momento mesmo do surgimento da gramaticografia ocidental; estabelecidos o campo de estudo gramatical e a teoria chamada gramática tradicional, temos os movimentos de gramatização dos vernáculos europeus no século XVI como impulsos para a formação das tradições francesa e brasileira de estudo da linguagem, onde a questão conceitual da frase será configurada em termos lógicolinguísticos agasalhados no termo base PROPOSIÇÃO e na técnica da análise lógica, que tem seus fundamentos na Grammaire de Port-Royal e na Logique ou l'art de penser. A tradição brasileira acompanha a francesa neste aspecto durante largo tempo, no entanto, vimos que, ainda no chamado período racionalista, encontram-se influxos do modo inglês de conceber a frase como estrutura intermediária entre a palavra e a proposição. Este estado de coisas na gramaticografia brasileira sofreu mudanças no período científico, o que, de algum modo, preparou o caminho para o início do período linguístico que tem seu início com os trabalhos de linguística geral de Mattoso Câmara.

O percurso acadêmico de Mattoso Câmara, tanto sua formação como sua produção bibliográfica, são testemunhos da mudança de contexto epistêmico que ocorreu no Brasil de começos do século XX: de uma visão histórico-comparativa dos fatos linguísticos passou-se a uma visão estrutural. Significou esta mudança também a ampliação da perspectiva de trabalho e de interesse dos estudiosos da linguagem brasileiros no plano de seus horizontes de retrospecção que foram enriquecidos com novas abordagens linguísticas vindas, sobretudo, da Europa, mas também da América do Norte. A linha de estudos estruturais inaugurada por Saussure, foi continuada por Charles Bally, Alan Gardiner e Albert Sechehayer a partir da tomada da parole como objeto de estudos, ensejando a emergência de teorias enunciativas modernas. É neste espectro teórico que vimos surgir em Mattoso as questões referentes à frase. Influíram aí 
a concepção estilística de Bally, a teoria pragmático-discursiva de Gardiner e a distinção conceitual promovida por Sechehaye entre frase da língua e frase do discurso. O contato feito por Mattoso com a Escola Linguística de Praga em sua viagem de estudos aos Estados Unidos da América, em 1943, permitiu-lhe ampliar e aprofundar sua compreensão teórica da frase, sobretudo a partir da teoria trifuncional da linguagem de Karl Bühler, da concepção dos níveis linguísticos de Bohumil Trnka e dos estudos sobre a entoação na caracterização da frase de Sergej Karcevski.

Observamos ao longo de todo o nosso estudo que a frase traz consigo como problema fundamental seu caráter fronteiriço; esteve sempre vinculada a duplas instâncias linguísticas: a dicção e a proposição; a construção e o juízo; a língua e o discurso. É no liame destes pares de constructos que, a nosso ver, reside a fonte do problema conceitual que, em Mattoso Câmara, foi elaborado nos termos da questão "É a frase elemento da língua?”. A esta questão, Mattoso respondeu positivamente, mas não sem antes esclarecer em que termos se dá esta pertença: por meio dos padrões frasais. Em seus termos:

Temos assim as frases da língua, ou tipos frasais (ing. sentence-patterns), que a análise lingüística pode deduzir, por abstração, das enunciações que são as frases dos discursos. São padrões sôbre os quais elas se desdobram, obrgatòriamente (CÂMARA JR., 1974, p. 165).

Enquadra, assim, a questão nos limites próprios da linguística propriamente dita, como soía considerar aquela iniciada no século XIX, a mesma, com as devidas atualizações promovidas pelos modelos estruturais de análise, que Mattoso divulgou nos restritos círculos de estudo da linguagem no Brasil, afastando-se definitivamente da influência lógico-filosófica que, por muito tempo, predominou na teorização da frase entre nós, bem como, de certo psicologismo linguístico que ameaçava, igualmente, desvirtuar tal questão no contexto Brasileiro.

Não chegou, no entanto, a tal solução por vias intuitivas, mas a partir da formação de um horizonte de retrospecção que, do mesmo modo, tomava a questão da conceituação da frase à sério e, dentro do contexto epistêmico linguístico, encaminhou a solução para os termos com os quais Mattoso Câmara formulou-a. Os fundamentos deste horizonte de retrospecção, como vimos, foram a visão de linguística geral de 
Edward Sapir, os instrumentos terminológicos da escola linguística inaugurada por Ferdinand de Saussure e os temas de interesse suscitados pelo Círculo Linguístico de Praga.

Nesta perspectiva, sustentamos que nossa hipótese se confirma na medida em que Mattoso Câmara reflete em seus trabalhos as mesmas questões de base que acompanham a história da ideia de frase: seu caráter fronteiriço, a variedade terminológica que a recobre, sua importância na reflexão sobre o uso linguístico, dentre outras; contribuiu, igualmente, para o esforço de precisão conceitual-terminológica da ideia de frase na medida em que os dois capítulos (XI e XII) de seu Princípios de linguística geral dedicados à questão da frase constituem ainda abrangente e importante estudo sobre os fundamentos de uma pertinente Teoria da Frase. 
Anexo I

Documento Notas para uma tese sobre sintaxe portuguesa e sua transcrição

P.I. Estudos - N.64

Descr. Doc: Notas para uma Tese sobre Sintaxe Portuguesa. ( em francês) $/$ s.d./

Notas: Estudos (2f. manuscritas)


126 
Esquisse de La Sangue Aortugaise.

1. Bharacteres Genéraut (le pertagries farmi les auties. Anngues romanes; comparacion avee P'cyiagnol-sa phonotojic comme be trait bistintif).

2. Les crigiries du ficrtugais etson expansion (apuoveith ait. Rev. Rcilt.)

3. La phonolegie patugaise, anigine des vayel les et des consonnes.

4. La maphotogie patugaise; crigine des merphènes.

5. La phrase pintugaise; tais distintifs, cencondance et collfcation.

6. Le Pexigue

127 


\section{Anexo II}

Páginas datilografadas de uma versão em português da História da linguística presente no Acervo Mattoso Câmara da Universidade Católica de Petrópolis

trátí dos hieroglifos egfpcios (1916). Como lingulista geral, GARDINBR ado tou a doutrina de SAUSSURB a nosse fundasento ascrevoul im importante livro sobre A Too-

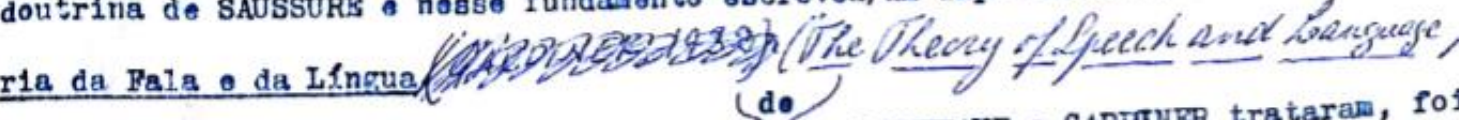

0 ponto contral da doutrina de SAUSSURB que SBCHISHAYB e GARIMIIR trataram, fos a distingäo ontre "fala" ou "discurso" o mfngua". sBCHBHAYB considerou a oposiglo entre o aspecto individual da fala o aspecto colotivo da lingua como sendo a essencia da dicotonta saussurfann. Por isso encarou a fala cono une espécie de lingua individual. o adaitiu a possibilidade de ura clencia da rala ("linguistique de $1 . a$ parole"). $\Lambda$ "trốs IIngưfsticas sauseurianas" sto, portanto, do seu ponto de vista o estudo diacronico da "Ingus", o estudo sincronico da "Ingus" a 0 estudo da "fala", ou "discurso", en diretrizes sincronicas. Fundamentou essa inter-

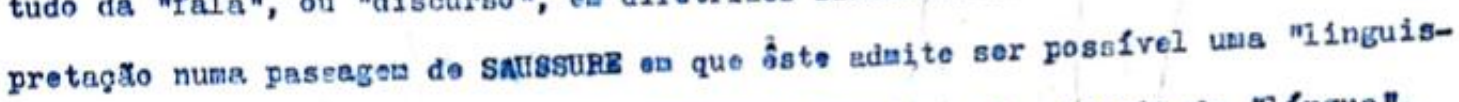
t1que da la parolo", embora em dirotrizes diversas das da ciencia da "Ińngua".

Por outro lado, sschinAYs so proocupars com o conflito entro o asrecto ind1vidual. o o coletivo na linguagem e tentou superar essa antinoulat 0 anago de sua soluģa a transpo-1a para as noseas proprias almas o derivta-la da nossa dupla condfg̨åo de individuos, cor una porsonalidade prßpria, a weiabros de uma sociedade, de que reseberas hábitos o estrauloe colotivos.

P1nalmonte, 6 digna de nota a atenglo que SBCHBHAYs emprestou aos probleass genśticos. Náf sua teorla da fraso, por exouplo, parto de un estágio prisitivo de "monorremas", 1sto 6 , conjuntos frasais Indivisiveis constituindo um só vocábulo fonético.

o livro de GARDINGR, como o título indica, tambem trata da cícotomia de fala - língus. GARDINBR focaliza a Pala nas inúmeras enunciaģos dos falantes de uma

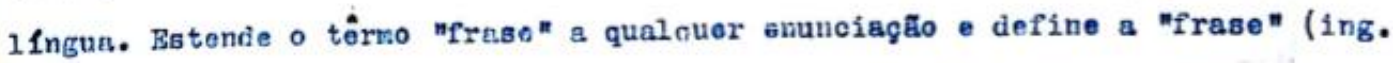
"sentence") on base psicológica, cowo sendo o resultado de "ua propósito inteligivel ". 0 grande árlto do livro 6, na realidade, o desenvolvimento de usa teoria 


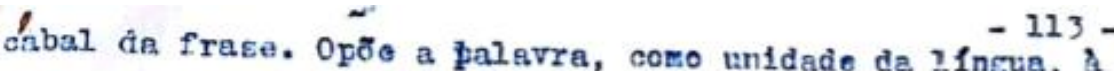
(ing."sentence"), que considera a unidade da rala. Pode-se depresender a nesma idsia om SAUSsURs, nas con a ressalva de que há tipos fixos de frase om toda Ifngua, de sorta que SBCHKHAYs, partindo daf, fez a distinga entre a fraso da lingua, 1s to 6 , o padräo sotoposto a toda enuncieģa, e a frase da fala, que $f$ a enunclagão om 51 mesma. Yosse ponto, o pensazento de SBCHKHAYs $a$ nais

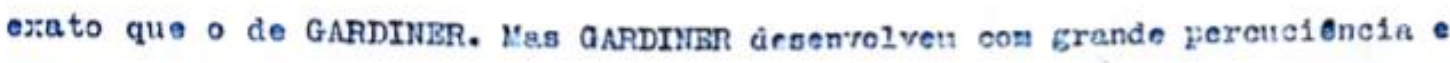
r1gor os aspectos complexos a intrinendos que acarpanhas e enunciagto ingtlist1ca. Vo a Prase como un drara ere m1ristura com quatro constituintes: o falan-

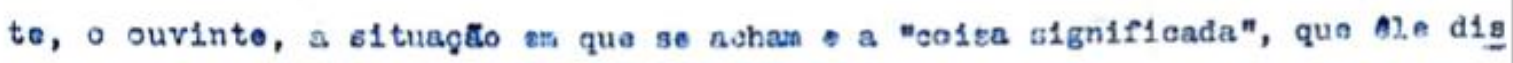
t1ngu cuidadosanto da signlelosgato 11ngatstica, que \& inerente a palavra, dela 1nseparírel, an paseo que a co1sk s1enifleadn \& ums referôncla concreta do Palante (Tozenos, por oxeaplo, o pronoxo "en", d1z-nos 10 . "Tal pronome ten an qualnuor a signtercagto do "o proprio falanto"; nas quando voce fala, a colsa significada por "oun 6 vocon), ( $d$.

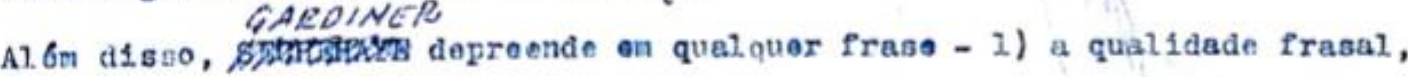
(o caríter da frasa que rovola o proposito especffico do falante), 2) a funģăo frasal ( "O que a frase realiza na sto eapacidade indicada pele sua qualidím do frasal especffica"), 3) a foras fressl, que of tanto "locucional" (carscterizada polo emprâgo particular de palavras e Eou arranjo) como "elocucional" (dependente preclpuamente da entoação). Insiste, for outro lado, no papol da nfuica. Podemos dizer que GARDINGR nos apresenta un quadro cabal o vivido do fenômeno da fale, ou, eu outros teruos, das condiggos concretas en que a a Ifngua se manifesta como weío de interourso na vida social.

Vol temo-nos agora para o 1 ingtista frances JOSKPH VMDHYas, que, como LBILLIFT, recebou a influencia de SAUSSURE o pertence so que denorinamos a ala francesa dos discípulos de SAUSSURB. 


\section{Anexo III}

Padrões frasais da língua portuguesa analisados em História e estrutura da língua portuguesa

1. PADRÃO NOMINAL

a. Nexo entre SUJEITO e PREDICADO (frase nominal)

i. SUJEITO ser PREDICADO Ex.: O homem é bom.

ii. SUJEITO estar PREDICADO Ex.: A vidraça está quebrada.

2. PADRÃO VERBAL

a. Nexo entre SUJEITO e PREDICADO (frase verbal)

i. [SUJEITO $1^{\mathrm{a}}$ OU $2^{\mathrm{a}}$ PESSOA] VERBO Ex.: Amo. Amas.

ii. ELE VERBO Ex.: Todos o escutam com entusiasmo, quando ele fala.

1. (SUJEITO) INTRANSITIVO (COMPLEMENTO) Ex.: Ando.

2. (SUJEITO) TRANSITIVO OBJETO Ex.: Vejo o menino. ( $O$ homem deve amar a Deus.) = FRASE NOMINAL PASSIVA Ex.: Esperamos os viajantes hoje. $=$ Os viajantes são esperados hoje.

3. (SUJEITO) INTRANSITIVO-RELATIVO OBJETO Ex.: Falo ao menino. (Vou a Paris. Vou ao menino. [complemento de direção])

4. PERÍFRASE VERBO-PRONOMINAL (Lat. Depoente)

a. Participação intensa do sujeito no que se expressa. Ex.: A estrada se estende. Um clamor se ergue.

b. Atividade em desdobramento. Ex.: Vive-se. Falou-se.

c. Supressão do sujeito. Ex.: Quebrou-se o vaso.

\section{i. COM OBJETO PRONOME}

1. OBJETO DIRETO Ex.: Amo-o.

2. OBJETO INDIRETO Ex.: Falo-lhe.

3. COMPLEMENTO DE DIREÇÃO Ex.: Vou a ele.

5. PADRÃO DE NEGAÇÃO

a. NÃO FRASE Ex.: Não amo.

b. PRONOME-INDEFINIDO-NEGATIVO FRASE Ex.: Não quero nada. Nada sei. Não vi ninguém. Ninguém chegou.

6. PADRÃO DE INTERROGAÇÃO (pergunta-resposta)

a. TEMA (predicado inteiro) - frase interrogativa total Ex.: É teu irmão?

i. FRASE - VERBO (resposta afirmativa) Ex.: Pedro saiu hoje? Saiu. É teu irmão? É

ii. FRASE - Não (resposta negativa) Ex.: Pedro saiu hoje? Não. É teu irmão? Não.

b. PRONOME-INDEFINIDO-INTERROGATIVO frase interrogativa parcial Ex.: Quem [é que] disse? Que [é que] ele faz? Qual dos livros [é que] ele quer? Quando [é que] você parte? Como [é que] você se feriu? [é que] ele está? 
i. FRASE - Elemento que preenche Ex.: Quem é que disse? O professor. Qual dos livros quer? Aquele. Que é que ele faz? Trabalha. Quando é que você parte? Amanhã.

c. [frase interrogativa - frase de resposta]:

7. PADRÃO DE COMPARAÇÃO

a. Comparativo (nominal e verbal): FRASE MAIS...QUE (DO QUE) Ex.: Públio é mais forte (do) que Tércio.

i. Inferioridade: MENOS... QUE (DO QUE) Ex.: Públio é menos forte que Tércio.

ii. Igualdade: TÃO... COMO (QUANTO) Ex.: (não apresenta)

8. PADRÃO DE SUBORDINAÇÃO

a. Formas nominais

b. QUE - unidade estrutural essencial

c. SE - formulação condicional Ex.: Se puder..., farei...

d. EMBORA - concessiva Ex.: Embora queira..., não consegue...

e. PARA QUE - final

f. Modo subjuntivo Ex.: É preciso que se explique...

9. PADRÃO DE IMPESSOALIDADE

a. Invariabilidade em número de um verbo na $3^{\mathrm{a}}$ pessoa / fenômenos atmosféricos

b. HAVER

c. PERIFRASE VERBO-PRONOMINAL (Inexistência de um nome substantivo na função de sujeito)

\section{MECANISMOS SINTÁTICOS}

1. REGÊNCIA

a. Nominal - DE

b. Verbal - A, PARA, EM, DE, POR, COM

2. CONCORDÂNCIA

a. Nominal

b. Verbal

3. COLOCAÇÃO

a. Atribuir ao último termo o máximo valor informativo

b. SUJEITO VERBO OBJETO (ordem direta)

c. NOME (substantivo) \{ NOME (adjetivo)

d. ADJETIVOS PRONOMINAIS / NÚMERO / QUANTIDADE INDEFINIDA \} NOME

e. POSPOSIÇÃO DO SUJEITO

i. Com verbos intransitivos

ii. Com verbos transitivos (sujeito e objeto direto são de número diferente)

iii. A compreensão geral do contexto o indica implicitamente

f. ORDEM INVERSA (hipérbato)

g. PRÓCLISE / ÊNCLISE

4. DIVISÃO FONOLÓGICA

a. GRUPOS DE FORÇA 


\section{REFERÊNCIAS}

ALI, Manuel Said. Gramática secundária da Língua Portuguesa. Ed. Revista e comentada por Evanildo Bechara. São Paulo: Melhoramentos, 1964.

ALTMAN, Cristina. A pesquisa linguística no Brasil (1968-1988). São Paulo: Humanitas/ FFLCH/ USP, 1998.

ALTMAN, Cristina. Filologia e linguística: outra vez. In.: Filologia e linguística portuguesa, n. 6, 2004 (pp. 161-98).

ALTMAN, Cristina. História, estórias e historiografia da linguística brasileira. In. Todas as Letras, São Paulo, v. 14, nº 1, pp.14-37, 2012.

ARISTÓTELES. Da interpretação. Tradução José Veríssimo Teixeira da Mata. São Paulo: UNESP, 2013.

ARISTÓTELES. Órganon. Tradução Edson Bini. 2 ed. revista. Bauru: Edipro, 2010.

ARISTÓTELES; HORÁCIO; LONGINO. A poética clássica. Tradução Jaime Bruna e Introdução Roberto de Oliveira Brandão. 12 ed. São Paulo: Cultrix, 2005.

AUROUX, Sylvain. A Questão da Origem das Línguas seguido de A Historicidade das Ciências. Tradução Mariângela Pecciolli Gali Joanilho. Campinas: Editora RG, 2008 (a).

AUROUX, Sylvain. A revolução tecnológica da gramatização. Trad. Eni Puccinelli Orlandi. Campinas: Ed. Unicamp, 2014.

AUROUX, Sylvain. Brève histoire de la proposition. Cahiers de l'ILSL, n. 25, pp. 1534, 2008 (b).

AUROUX, Sylvain. Filosofia da linguagem. Trad. Marcos Marcionilo. São Paulo: Parábola, 2009.

AUROUX, Sylvain. Histoire des sciences et entropie des systèmes scientifiques. In: Archives et documents de la Société d'histoire et d'épistémologie des sciences du langage, Première série, $n^{\circ}$ 7, pp. 1-26, 1986.

AUROUX, Sylvain. Indroducion. In: Histoire des idées linguistiques - tome 1, La naissance des métalangages en orient et en occident. Liège: Mardaga, 1989.

AUROUX, Sylvain. L'histoire de la linguistique. In: Langue française, Histoire de la linguistique française, n. 48, pp. 7-15, 1980.

AUROUX, Sylvain. La notion de linguistique générale. In: Histoire Épistémologie Langage, Antoine Meillet et la linguistique de son temps, tome 10, fascicule 2, pp. 37$56,1988$.

AUROUX, Sylvain. Les modes d'historicisation. In.: Histoire Épistémologie Langage, Histoire des idées linguistiques et horizons de rétrospection, tome 28 , fascicule 1 , pp. 105-16, 2006. 
AUROUX, Sylvain; COLOMBAT, Bernard. L'horizon de rétrospection des grammairiens de l'Encyclopédie. In.: Recherches sur Diderot et sur l'Encyclopédie, Société Diderot, 1999.

BACHELAR, Gaston. Epistemologia. Trechos escolhidos por Dominique Lecourt. Tradução Nathanael C. Caixeiro. Rio de Janeiro: Zahar, 1977.

BAILLY, Anatole. Dictionnaire grec-français. Paris: Hachette, 2018.

BARBOSA, Jeronimo Soares. Grammatica philosophica da Lingua Portugueza. Lisbonne: Typographia de Academia das Sciencias, 1822.

BECHARA, Evanildo. Moderna gramática portuguesa. 37 ed. Rio de Janeiro: Nova Fronteira, 2009.

BECKER, Idel. Pequena história da civilização ocidental. 11 ed. São Paulo: Ed. Nacional, 1980.

BORGES NETO, José. Gramática tradicional e linguística contemporânea: continuidade ou ruptura? In.: Todas as Letras, São Paulo, v. 14, n. 1, pp. 87-98, 2012.

CABRAL, Nilda. Aplicação da crítica textual a textos científicos como o de Princípios de Linguística Geral, de Mattoso Câmara Jr. In.: Confluência, Rio de Janeiro, 27/28, pp. 105-118, 2004.

CABRAL, Nilda. Variação e variantes nas edições de Princípios de Lingüística Geral de Matoso Câmara Jr: questões filológicas e linguísticas. In.: Confluência, Rio de Janeiro, 29/30, pp. 221-238, 2005.

CÂMARA JR, Joaquim Mattoso. Crônica linguística: a teoria sintagmática de Mikus [1956]. In.: CÂMARA JR., Joaquim Mattoso. Dispersos. Seleção e introdução de Carlos Eduardo Falcão Uchôa. 2 ed. Rio de Janeiro: FGV, 1975. (pp. 15-31)

CÂMARA JR, Joaquim Mattoso. Estrutura da língua portuguesa. 16 ed. Petrópolis: Vozes, 1986.

CÂMARA JR, Joaquim Mattoso. História da linguística. 4 ed. Tradução Maria do Amparo Barbosa de Azevedo. Petrópolis: Vozes, 1986.

CÂMARA JR, Joaquim Mattoso. Nomenclatura gramatical [1960]. In.: CÂMARA JR., Joaquim Mattoso. Dispersos. Seleção e introdução de Carlos Eduardo Falcão Uchôa. 2 ed. Rio de Janeiro: FGV, 1975. (pp. 55-70)

CÂMARA JR, Joaquim Mattoso. O estruturalismo linguístico. In.: Tempo Brasileiro, Rio de Janeiro, 15/16, pp. 5-43, 1968.

CÂMARA JR, Joaquim Mattoso. Os estudos de português no Brasil [1966]. In.: CÂMARA JR., Joaquim Mattoso. Dispersos. Seleção e introdução de Carlos Eduardo Falcão Uchôa. 2 ed. Rio de Janeiro: FGV, 1975. (pp. 197-232).

CÂMARA JR, Joaquim Mattoso. Princípios de linguística geral: como fundamento para os estudos superiores da língua portuguesa. Rio de Janeiro: F. Briguiet, 1942. 
CÂMARA JR, Joaquim Mattoso. Princípios de linguística geral: como introdução aos estudos superiores da língua portuguesa. 2 ed. rev. e aum. Rio de Janeiro: Livraria Acadêmica, 1954.

CÂMARA JR, Joaquim Mattoso. Princípios de linguística geral: como introdução aos estudos superiores da língua portuguesa. 3 ed. rev. e aum. Rio de Janeiro: Livraria Acadêmica, 1959.

CÂMARA JR, Joaquim Mattoso. Princípios de linguística geral: como introdução aos estudos superiores da língua portuguesa. 4 ed. rev. e aum. Rio de Janeiro: Livraria Acadêmica, 1974.

CAMARA JR, Joaquim Mattoso. Gramática $-1^{a}$ e $2^{a}$ séries ginasiais e $3^{a}$ e $4^{a}$ séries ginasiais. In: CAMARA Jr, Joaquim Mattoso; LIMA, Carlos Henrique da Rocha. Curso da língua pátria. Rio de Janeiro Briguiet, 1944-1945.

CÂMARA JR, Joaquim Mattoso. Dicionário de filologia e gramática: referente à língua portuguesa. Rio de Janeiro: J. Ozon, 1970.

CÂMARA JR, Joaquim Mattoso. Lições de Lingüística Geral: I a XII. In.: Revista de Cultura 25 (146):99-104, 25 (148):183-189, 25 (149):216-222, 25 (149/150):270-284, 26 (151):43-47, 26 (152/153/ 154):81-86, 26 (155/156):77-185, 27 (157):21-27, 27 (158):83-88, 27 (159/160):141-146, 27 (161/162): 202-208, 28 (163): 11-17. Rio de Janeiro: Briguiet, 1939-1940.

CÂMARA JR, Joaquim Mattoso. Manual de expressão oral e escrita. 5 ed. Petrópolis: Vozes, 1978.

CÂMARA JR, Joaquim Mattoso. Para uma estilística estrutural. In.: Confluência, Rio de Janeiro, 27/28, pp. 298-306, 2004.

CANECA, Frei. Breve Compendio de Grammatica Portugueza - organisado em forma systematica, com adaptação a capacidade dos alumnos. Recife: Typographia Mercantil, 1876.

CARVALHO, Antonio José de; DEUS, João de. Diccionario prosodico de Portugal e Brazil. 5 ed. Porto: Rio de Janeiro: Lopes \& cia, 1885.

CARVALHO, Olavo de. Aristóteles em nova perspectiva: introdução à Teoria dos Quatro Discursos. 2 ed. Campinas: Vide Editorial, 2013.

CAVALIERE, Ricardo. A gramática no Brasil: ideias, percursos, parâmetros. Rio de Janeiro: Lexikon, 2014.

CAVALIERE, Ricardo. Uma proposta de periodização dos estudos linguísticos no Brasil. In.: Alfa, São Paulo, 45, pp. 49-69, 2001.

CHAPANSKI, Gissele. Uma tradução da Tékhne Grammatikê, de Dioníso Trácio, para o português. Dissertação apresentada à área de concentração Estudos Linguísticos da Universidade Federal do Paraná em 2003. 
COELHO, Olga. Mattoso Câmara e os ambíguos primeiros passos da linguística sincrônica no Brasil (1940-1960). In.: Confluência, Rio de Janeiro, 17/28, pp. 95-104, 2004.

COLOMBAT, Bernard; FOURNIER, Jean-Marie; PUECH, Christian. Uma história das ideias linguísticas. Tradução Jacqueline Léon e Marli Quadros Leite. São Paulo: Contexto, 2017. (Título original: Histoire des ideés sur langage et les langues)

COSERIU, Eugenio. Diez tesis a propósito de la esencia del linguaje y del significado. Traducción de Mónica Castillo Lluch y Johannes Kabatek. In.: Energeia IV, pp. 49-52, 2012.

COSERIU, Eugenio. El hombre y su lenguaje: estudios de teoría y metodología lingüística. 2 ed. Revisada. Madrid: Gredos, 1991.

COSERIU, Eugenio. Lingüística del texto: introducción a la hermenéutica del sentido. Madrid: Arco/Libros, 2007.

COSERIU, Eugenio. Teoría del lenguaje y lingüística general. 2 ed. Madrid: Gredos, 1969.

COSERIU, Eugenio; LAMAS, Óscar Loureda. Linguagem e discurso. Trad. Cecília Ines Erthal. Curitiba: Ed. UFPR, 2010.

CRUZ, José Marques da. Português prático: gramática. 25 ed. São Paulo: Melhoramentos, 1955.

CUNHA, Albertina; ALTGOTT, Maria Alice Azevedo. Para compreender Mattoso Câmara. Petrópolis: Vozes, 2004.

CUNHA, Celso. Gramática do português contemporâneo. Editora Bernardo Álvares, 1970.

DELESALLE, Simone. L'étude de la phrase. In: Langue française, Linguistique et enseignement du français, $n^{\circ} 22$, pp. 45-67, 1974.

DESBORDES, Françoise. Les idées sur le langage avant la constitution des disciplines spécifiques. In.: AUROUX, Sylvain (Dir.). Histoire des idées linguistique. Tome I La naissance des métalangages en Orient et em Occident. Liege-Bruxelles: Pierre Mardaga, 1989.

DUBOIS, Jean. Dicionário de linguística. Direção e coordenação da tradução Izidoro Blikstein. São Paulo: Cultrix, 1978.

DUCROT, Oswald; TODOROV, Tzvetan. Dicionário enciclopédico das ciências da linguagem. Trad. Alice Kyoko Miyashiro, J. Guinsburg, Mary Amazonas Leite de Barros e Geraldo Gerson de Souza. São Paulo: Perspectiva, 2010.

FARIA, L. de Castro. Introdução. In.: CÂMARA JR. Joaquim Mattoso. Introdução às línguas indígenas brasileiras. Rio de Janeiro: Liv. Acadêmica, 1965.

FÁVERO, Leonor Lopes. De Moraes Silva a João Ribeiro - contribuição à história da gramática no Brasil. Confluência, São Paulo, v. 27/28, p. 251-261, 2005. 
FÁVERO, Leonor Lopes; MOLINA, Márcia A. Conhecimento linguístico no século XIX: tradição e "modernidade"? In.: Linguística, vol. 29 (1), pp. 189-203, junho 2013.

FLUSSER, Vilém. Língua e realidade. 3 ed. São Paulo: Annablume, 2007.

FRANÇA, Angela Maria Ribeiro. Mattoso Câmara e o vocábulo-problema de 19391940. In.: Anais do III Congresso Nacional de Lingüística e Filologia. Disponível em: http://www.filologia.org.br/cong_iiicnlf.html Acesso em: 06 abr. 2018.

FRANÇA, Angela Maria Ribeiro. Texto e contexto nos escritos lingüísticos de Mattoso Câmara: 1938-1954. Dissertação apresentada à área de concentração Semiótica e Linguística Geral, do Departamento de Linguística da Faculdade de Filosofia, Letras e Ciências Humanas da Universidade de São Paulo em 1998.

GARDINER, Alan H. The theory of speech and language. Oxford: Clarendon Press, 1932.

GEIGER, Paulo (org.). Caldas Aulete minidicionário contemporâneo da língua portuguesa. 3 ed. Rio de Janeiro: Lexiton, 2011.

GRAFFI, Giorgio. 200 Years of Syntax. Amsterdam/ Philadelphia: John Benjamins Publishing Company, 2001.

GRAFFI, Giorgio. Sulla traduzione di LOGOS nel cap. 20 della poética di Aristotele. Disponível em: http://univr.academia.edu/GiorgioGraffi Acesso em: 06 abr. 2018 .

GUIRAUD, Charles. Le verbe est-il centre de phrase? In.: L'Information Grammaticale, n. 2, pp. 35-8, 1979.

HACKEROTT, M. M. S.; ALMEIDA, M. E. . Mattoso Camara: da gramática do Curso da língua pátria ao Manual de expressão oral e escrita. In: Bastos,N.M.O.B.; PALMA, D.V.. (Org.). História entrelaçada 6 - Língua portuguesa na década de 1960: linguística, gramática e educação. Rio de Janeiro: Nova Fronteira, 2014.

HAMPEJS, Zdenek. Filologos brasileiros. Separata del "Boletín de Filología", publicación del Instituto de Filología de la Universidad de Chile. Tomo XIII, 1961.

HAUY, Amini Boainain. Da necessidade de uma gramática-padrão da Língua Portuguesa. São Paulo: Ática, 1983.

HAUY, Amini Boainain. Gramática da Língua Portuguesa Padrão. São Paulo: Edusp, 2015.

HUISMAN, Denis. Dicionário dos filósofos. São Paulo: Martins Fontes, 2004.

ILDEFONSE, Frédérique. La naissance de la grammaire dans l'antiquité grecque. Paris: Librairie Philosophique J. Vrin, 1997.

KEHDI, Valter. A morfologia e a sintaxe portuguesa na obra de J. Mattoso Câmara Jr. Tese de livre-docência. São Paulo, FFLCH-USP, 1998.

KEHDI, Valter. A sintaxe de J. Mattoso Câmara Jr.: novas considerações. In: Confluência, Rio de Janeiro, n. 29-30, p. 249-253, 2005. 
KEHDI, Valter. A sintaxe em Mattoso Câmara. In.: D.E.L.T.A. São Paulo, 20, pp. 105$127,2004$.

KNITTERMEYER, Hinrich. A filosofia moderna: de Nicolau de Cusa a Nietzsche. In.: HEINEMANN, Fritz. A filosofia no século XX. Trad. Alexandre F. Morujão. Lisboa: Calouste Gulbenkian, 1969.

KOERNER, E. F. K.. Linguística e filologia: o eterno debate. In. KOERNER, E. F. K.. Quatro décadas de historiografia linguística: estudos selecionados. Seleção e edição de Rolf Kemmler e Cristina Altman. Braga: Centro de Estudos em Letras / Universidade de Trás-os-Montes e Alto Douro, 2014.

LAMAS, Óscar Loureda. Presentación del editor: la Textlinguistik de Eugenio Coseriu. In.: COSERIU, Eugenio. Linguiística del texto: introducción a la hermenêutica del sentido. Madrid: Arco/Libros, 2007.

LAW, Vivien. The history of linguistics in Europe: from Plato to 1600. Cambridge: Cambridge University Press, 2003.

LEITE, Marli Quadros. O nascimento da gramática portuguesa: uso e norma. São Paulo: Paulistana; Humanitas, 2007.

LÉON, Jacqueline. Proposition, phrase, énoncé dans la grammaire: Parcours historique. In: L'Information Grammaticale, n. 98, pp. 5-16, 2003.

LEROY, Maurice. As grandes correntes da linguística moderna. 2 ed. Trad. Izidoro Blikstein e José Paulo Paes. São Paulo: Cultrix, 1971.

LONERGAN, Bernard. Método em teologia. Tradução Hugo Langone. São Paulo: É Realizações, 2012.

LOWTH, Robert. Short introduction to the English grammar. Philadelphia: R. Aitken, 1799. Disponível em: https://archive.org/details/shortintroductio00lowtrich Acesso em: 06 abr. 2018.

LUPETTI, Monica. A gramática racionalista em Portugal no século XVIII. In. DUARTE, Sónia; LÉON, Rogelio Ponce de (org.). A gramática racionalista na Península Ibérica (séculos XVI-XIX). Porto: Flup, 2015.

MACIEL, Maximino. Grammatica Descriptiva. Rio de Janeiro: Livraria Francisco Alves, 1914.

MADRE OLÍVIA (Cilia Coelho Pereira Leite). Nova análise semântica. São Paulo: J. Ozon, 1970.

MARCHELLO-NIZIA, Christiane. La notion de "phrase" dans la grammaire. In. Langue française, Sur la grammaire traditionnelle, n. 41, pp. 35-48, 1979.

MATA, José Veríssimo Teixeira da. Notas. In.: ARISTÓTELES. Da interpretação. Trad. José Veríssimo Teixeira da Mata. São Paulo: Ed. Unesp, 2013.

MATOS, Francisco Gomes de. Mattoso Camara Jr. e o ensino da lingüística no Brasil. In.: Revista de Cultura Vozes: estudos lingüísticos em homenagem a J. Mattoso Camara Jr., N. 5, Ano 67, pp. 73-7, 1973. 
MATTOS E SILVA, Rosa Virgínia. Meu diálogo constante com Joaquim Mattoso Câmara Jr. In.: Estudos Linguiísticos XXXIV, pp. 28-43, 2005. Disponível em: http://www.gel.hospedagemdesites.ws/estudoslinguisticos/edicoesanteriores/4publicaestudos-2005/4publica-estudos-2005-pdfs/1-convidadorosavirginia.pdf?SQMSESSID=a38ffc79c82bcbe561e1c641326fd16c Consultado em 06 abr. 2018.

MATTOS E SILVA, Rosa Virgínia.. Tradição gramatical e gramática tradicional. São Paulo: Contexto, 2016.

McLUHAN, Marshall. O Trivium Clássico: o lugar de Thomas Nashe no ensino de seu tempo. Trad. Hugo Langone. São Paulo: É realizações, 2012.

MORA, J. Ferrater. Dicionário de filosofia. 4 tomos. Trad. Vários. 2 ed. São Paulo: Loyola, 2004.

NARO, Anthony Julius (Org.). Tendências atuais da linguística e da filologia no Brasil. Tradução Maria Candida D. Bordenave e Marilda Wilkler Averbug. Rio de Janeiro: Livraria Francisco Alves, 1976.

NEVES, Maria Helena de Moura. A vertente grega da gramática tradicional. 2 ed. São Paulo: Ed. UNESP, 2005.

PAGLIARO, Antonio. A vida do sinal: ensaios sobre a língua e outros símbolos. Lisboa: Fundação Calouste Gulbenkian, 1967.

PAGLIARO, Antonio. Logica e grammatica - Eraclito B 1. In «Ricerche Linguistiche», $1, \quad$ p. $1-57 . \quad$ Disponível em : https://web.uniroma1.it/storiaideelinguistiche/antonino-pagliaro/antonino-pagliaro Acesso em: 06 abr. 2018.

POLACHINI, Bruna Soares. O tratamento da sintaxe em gramáticas brasileiras do século XIX: estudo historiográfico. Dissertação apresentada ao Programa de PósGraduação em Semiótica e Linguística Geral, da Faculdade de Filosofia, Letras e Ciências Humanas da Universidade de São Paulo, em 2013.

POLACHINI, Bruna Soares. Uma história serial e conceitual da gramática brasileira oitocentista de Língua Portuguesa. Tese apresentada ao Programa de PósGraduação em Semiótica e Linguística Geral, da Faculdade de Filosofia, Letras e Ciências Humanas da Universidade de São Paulo, em 2018.

REIS, Francisco Sotero dos. Grammatica portugueza, accommodada aos principios geraes da palavra, seguidos de immediata applicação prática. 2 ed. Maranhão: Typ. de R. de Almeida \& C., 1871.

RIBEIRO, João. Diccionario grammatical. 3 ed. Belo Horizonte : Livraria Francisco Alves, 1906.

RIBEIRO, João. Grammatica portugueza: curso superior. 19 ed. Rio de Janeiro: Livraria Francisco Alves, 1920.

RIBEIRO, Júlio. Grammatica portugueza. 2 ed. Margão: Typographie d'Ultramar, 1885 . 
RIGHI, Gaetano. Historia de la filologia clásica. 2 ed. Tradução J. M. García de la Mora. Barcelona: Labor, 1969.

ROCHA LIMA, Carlos Henrique da. Gramática normativa da Língua Portuguesa. 53 ed. Rio de Janeiro: José Olympio, 2017.

RODRIGUES, Aryon Dall'Igna. A obra científica de Mattoso Câmara Jr. In. Estudos da Língua(gem). Vitória da Conquista, 2, pp. 11-28, dez. 2005.

SAPIR, Edward. A linguagem: introdução ao estudo da fala. Tradução, introdução e apêndice J. Mattoso Câmara Jr. 2 ed. São Paulo: Perspectiva, 2013.

SCHMIDT, Maria Auxiliadora. História com pedagogia: a contribuição da obra de Jonathas Serrano na construção do código disciplinar da História do Brasil. In.: Rev. Bras. Hist., vol.24, n.48, pp. 189-211, 2004.

SCHWARTZMAN, Simon. Um espaço para a ciência: a formação da comunidade científica no Brasil. 4 ed. Campinas: Unicamp, 2015.

SEGUIN, Jean-Pierre. L'invention de la Phrase au XVIIIe Siècle. Louvain/Paris: Éditions Peeters, 1993.

SILVA, Antonio de Moraes. Epitome da grammatica da lingua portugueza. Lisbonne, Simão Thaddeo Ferreira, 1806.

SILVA, Antônio Moraes. Diccionario da língua portuguesa composto pelo padre $\mathbf{D}$. Rafael Bluteau. Tomo Segundo. Lisboa: Simão Thaddeo Ferreira, 1789.

SILVA, Antônio Moraes. Diccionario da lingua portuguesa. Tomo II. 4 ed. Lisboa: Impressão Regia, 1831.

SILVA, Maurício. Gramática da língua portuguesa no Brasil: um estudo da gramaticografia brasileira Pré-NGB (1930-1960). In. Papéis. Campo Grande, v. 18, n. 35, pp. 154-168, 2014.

SOUZA, Jorge Máximo. Mario Pereira de Souza Lima: uma etapa de consolidação do pensamento gramatical brasileiro anterior à NGB. Tese apresentada ao Programa de Pós-Graduação em Letras, da Universidade do Estado do Rio de Janeiro. Rio de Janeiro: 2011. Disponível em: http://www.bdtd.uerj.br/tde_busca/arquivo.php?codArquivo=3222

SWIGGERS, Pierre. Histoire de la pensée linguistique. Paris: Press Universitaires de France, 1997.

SWIGGERS, Pierre. Modelos, métodos y problemas en la historiografía de la lingüística. Nuevas aportaciones a la historiografia linguiística. Actas del IV Congresso Internacional de la SEHL. La Laguna (Tenerife), 22-25 octubre de 2003, ed. Corrales Zumbado, C.; Dora Luis, J. et al. Madrid: Arco Libros, 2005 [2004]. (p. 113-145)

TODOROV, Tzvetan. Teorias do símbolo. Trad. Roberto Leal Ferreira. São Paulo: Ed. Unesp, 2014. 
TOURAINE, Alain. Crítica da modernidade. Trad. Fátima Gaspar e Carlos Gaspar. Lisboa: Instituto Piaget, 1992.

UCHÔA, Carlos Eduardo Falcão. Os estudos linguísticos e a carreira de Joaquim Mattoso Câmara Jr. In.: CÂMARA JR., Joaquim Mattoso. Dispersos. Seleção e introdução de Carlos Eduardo Falcão Uchôa. 2 ed. Rio de Janeiro: FGV, 1975.

VALLE, Rosalvo do. Mattoso Câmara e a História da Língua Portuguesa. In. Confluência, 27/28, 1. ${ }^{\circ}$ e $2 .^{\circ}$ semestres de 2004.

WILPERT, Paul. A filosofia na Antiguidade Greco-Romana. In.: HEINEMANN, Fritz. A filosofia no século XX. Trad. Alexandre F. Morujão. Lisboa: Calouste Gulbenkian, 1969. 